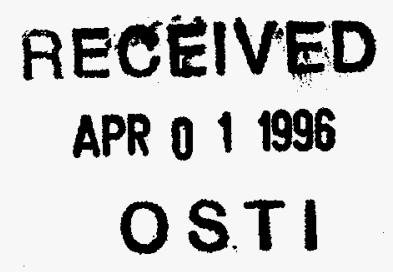

\title{
UMTRA Ground Water Project MANAgement ACtion Process DOCUMENT
}

March 1996

\section{DISCLAIMER}

This report was prepared as an account of work sponsored by an agency of the United States Government. Neither the United States Government nor any agency thereof, nor any of their employees, makes any warranty, express or implied, or assumes any legal liability or responsibility for the accuracy, completeness, or usefulness of any information, apparatus, product, or process disclosed, or represents that its use would not infringe privately owned rights. Reference herein to any specific commercial product, process, or service by trade name, trademark, manufacturer, or otherwise does not necessarily constitute or imply its endorsement, recommendation, or favoring by the United States Government or any agency thereof. The views and opinions of authors expressed herein do not necessarily state or reflect those of the United States Government or any agency thereof. 


\section{INTENPED FOR,PUBLIC RELEASE}

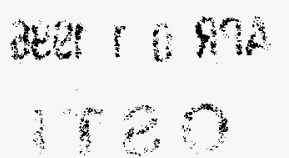

This report has been reproduced from the best available copy. Available in paper copy and microfiche

Number of pages in this report: 98

DOE and DOE contractors can obtain copies of this report from:

Office of Scientific and Technical Information

P.O. Box 62

Oak Ridge, TN 37831

(615) 576-8401

This report is publicly available from:

National Technical Information Service

Department of Commerce

5285 Port Royal Road

Springfield, VA 22161

(703) 487-4650
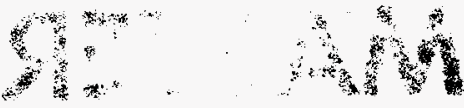
DOE/AL/62350-220

Rev. 0

\section{UMTRA GROUND WATER PROJECT \\ MANAGEMENT ACTION PROCESS DOCUMENT}

Work performed under DOE Contract No. DE-AC04-91AL62350.

March 1996

Prepared for

U.S. Department of Energy

Grand Junction Projects Office 



\section{TABLE OF CONTENTS}

\section{Section}

1.0 INTRODUCTION ..................................................................................... 1-1

1.1 Purpose of management action process............................................ $1-2$

1.2 Organization of the map document.................................................. $1-2$

1.3 Environmental restoration objectives ................................................. $1-4$

1.4 Accomplishments............................................................................. 1-6

1.4.1 Activities accomplished ....................................................... 1-6

1.4.2 Scheduled for completion in FY1996 ...................................... 1-7

1.5 Project team ................................................................................. $1-7$

1.6 Organizational interfaces................................................................. $1-7$

1.7 Status of management action process............................................... 1-7

1.8 Strategy for management action process .......................................... $1-9$

2.0 SITE DESCRIPTIONS AND COMPREHENSIVE PLANNING ........................... 2-1

2.1 Operational history ......................................................................... $2-1$

2.2 Environmental setting .............................................................. 2-3

2.3 Current site and adjacent land uses................................................. $2-3$

2.4 Facilities, infrastructure, and equipment............................................ $2-3$

2.5 Influencing factors ....................................................................... $2-3$

2.6 Future uses of land, facilities, and equipment ....................................... $2-7$

3.0 STATUS OF ENVIRONMENTAL RESTORATION ACTIVITIES .......................... $3-1$

3.1 Current environmental restoration activities .......................................... $3-1$

3.2 Regulatory agreements, consent decrees, compliance, and
other legal drivers ........................................................................ $3-3$

3.3 Current waste management and material disposition activities ................... 3-3

3.4 Nonregulatory activities ................................................................... $3-3$

3.4.1 Public involvement process .................................................... $3-3$

3.4.2 Program management ....................................................... $3-6$

4.0 SITE RELATIVE RANKING ..................................................................... 4

4.1 UMTRA priority categorization ...................................................... 4-1

4.2 ER relative risk ranking ................................................................. 4-3

4.3 ITR liability ranking ..................................................................... 4-3

4.4 Correlation of ranking models ........................................................... 4-3

5.0 ENVIRONMENTAL RESTORATION STRATEGY ......................................... $5-1$

5.1 Key assumptions ........................................................................ $5-1$

5.2 Strategy for remedy selection .......................................................... $5-2$

5.3 Regulatory activity strategy........................................................... $5-4$

5.4 Nonregulatory activity strategy .................................................. $5-4$

5.5 Performance measures ................................................................. $5-4$

6.0 ENVIRONMENTAL RESTORATION PROGRAM MASTER SCHEDULE .................. 6-1 


\section{TABLE OF CONTENTS (Concluded)}

\section{Section}

7.0 ISSUES TO BE RESOLVED

8.0 REFERENCES.

APPENDIX A FISCAL YEAR FUNDING REQUIREMENTS

APPENDIX B MAJOR ENVIRONMENTAL RESTORATION DOCUMENTS

APPENDIX C DECISION DOCUMENT RECORD OF DECISION SUMMARIES

APPENDIX D CONCEPTUAL MODEL DATA SUMMARIES

APPENDIXE PROJECT CONTROLS 


\section{LIST OF FIGURES}

Figure

1.0-1 Site location map

1.5-1

Organizational interfaces

2.2-1 Sulfate concentrations in ground water, Ambrosia Lake, New Mexico, site.... 2-8

2.2-2 Uranium concentrations in ground water, Canonsburg, Pennsylvania, site...... 2-9

2.2-3 Chloride concentrations in ground water, Durango, Colorado, site................ 2-10

2.2-4 Sulfate concentrations in ground water, Durango, Colorado, site ................. 2-11

2.2-5 Tailings-contaminated ground water, Falls City, Texas, site ....................... 2-12

2.2-6 Uranium concentrations in ground water, Grand Junction, Colorado, site....... 2-13

2.2-7 Uranium concentrations in ground water, Green River, Utah, site................. 2-14

2.2-8 Sulfate concentrations in ground water, Gunnison, Colorado, site................. 2-15

2.2-9 Sulfate concentrations in ground water, Lakeview, Oregon, site ................. 2-16

2.2-10 Nitrate and uranium concentrations in ground water, Maybell,

Colorado, site

2.2-11 Tailings-contaminated ground water, Mexican Hat, Colorado, site................ 2-18

2.2-12 Nitrate concentrations in ground water, Monument Valley, Arizona, site....... 2-19

2.2-13 Uranium concentrations in ground water, Naturita, Colorado, site ................ 2-20

2.2-14 Sulfate concentrations in ground water, New Rifle, Colorado, site ............... 2-21

2.2-15 Sulfate concentrations in ground water, Old Rifle, Colorado, site ................ 2-22

2.2-16 Uranium concentrations in ground water, Riverton, Wyoming, site.............. 2-23

2.2-17 Sulfate concentrations in ground water, Salt Lake City, Utah, site ............... 2-24

2.2-18 Uranium concentrations in ground water, Shiprock, New Mexico, site.......... 2-25

2.2-19 Uranium concentrations in ground water, North Continent and Union

Carbide processing sites, Slick Rock, Colorado ..................................... 2-26

2.2-20 Tailings-contaminated ground water, Spook, Wyoming, site...................... 2-27

2.2-21 Nitrate concentrations in ground water, Tuba City, Arizona, site.................. 2-28

5.2-1 Logic framework .................................................................. $5-6$

6.0-1 Ground water summary (FY1998 budget) .................................... $6-2$ 


\section{LIST OF TABLES}

Table

Page

1.5-1 Project team ........................................................................... 1-8

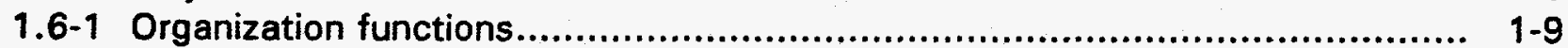

2.1-1 History of Project operation........................................................ $2-2$

2.2-1 Environmental setting and current land use ........................................ $2-4$

2.2-2 Environmental condition of property ............................................... $2-5$

3.1-1 Targeted site compliance strategies ............................................. $3-2$

3.1-2 Summary of potential impacts of the ground water compliance strategies....... 3-4

3.2-1 Scheduled cooperative agreements ............................................... $3-5$

4.0-1 Site relative rankings ........................................................... $4-2$

7.0-1 Recommendations and proposed actions ....................................... $7-2$ 


\section{LIST OF ACRONYMS}

Acronym

AEC

$A L$

BLRA

DOE

EA

EM-40

EPA

ER

FOS

FY

GJPO

$\mathrm{HQ}$

ITR

MAP

$M C L$

NEPA

NPL

NRC

PCS

PEIS

PIP

RDS

ROD

RRM

SIP

SOS

SOWP

TAR

TEC

UMTRA

UMTRCA

VP

\section{Definition}

Atomic Energy Commission

Albuquerque

baseline risk assessment

U.S. Department of Energy

environmental assessment

Office of Environmental Restoration

U.S. Environmental Protection Agency

Environmental Restoration

Facility Operations and Support

fiscal year

Grand Junction Projects Office

Headquarters

independent technical review

management action process

maximum concentration limits

National Environmental Policy Act

National Priority List

U.S. Nuclear Regulatory Commission

Project Control System

programmatic environmental impact statement

public involvement process

risk data sheets

record of decision

residual radioactive material

stabilized in place

stabilized on site

site observational work plan

Technical Assistance and Remediation

total estimated costs

Uranium Mill Tailings Remedial Action

Uranium Mill Tailings Radiation Control Act

vicinity property 


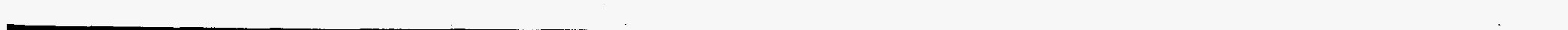




\subsection{INTRODUCTION}

A critical U.S. Department of Energy (DOE) mission is to plan, implement, and complete DOE Environmental Restoration (ER) programs at facilities that were operated by or in support of the former Atomic Energy Commission (AEC). These facilities include the 24 inactive processing sites the Uranium Mill Tailings Radiation Control Act (UMTRCA) (42 USC $\$ 7901$ et seq.) identified as Title I sites, which had operated from the late 1940s through the 1970s. In UMTRCA, Congress acknowledged the potentially harmful health effects associated with uranium mill tailings and directed the DOE to stabilize, dispose of, and control the tailings in a safe and environmentally sound manner. The UMTRA Surface Project deals with buildings, tailings, and contaminated soils at the processing sites and any associated vicinity properties (VP). Surface remediation at the processing sites will be completed in 1997 when the Naturita, Colorado, site is scheduled to be finished.

The UMTRA Ground Water Project was authorized in an amendment to the UMTRCA 142 USC \$7922(a)l, when Congress directed DOE to comply with U.S. Environmental Protection Agency (EPA) ground water standards. The UMTRA Ground Water Project addresses any contamination derived from the milling operation that is determined to be present at levels above the EPA standards.

The UMTRA Ground Water Project is funded under the DOE ER Program and managed by the DOE Grand Junction Projects Office (GJPO). The UMTRA Ground Water Project (hereinafter called the Project) mission is to implement compliance strategies that will ensure protection of human health and the environment from ground water contaminated by past operations at the 24 sites (Figure 1.0-1). These sites are located in 10 states and on 4 Indian tribal lands. At many of these former mill sites, contaminated ground water is migrating or already has migrated off the site. DOE has no controls in place at these sites to minimize any potential human health and environmental impacts associated with this offsite ground water contamination. The U.S. Nuclear Regulatory Commission (NRC) is the UMTRA Project regulatory agency that will ensure DOE compliance with EPA standards. The NRC also is authorized to license or certify the cleanup and closure of the UMTRA Project sites. DOE works in partnership with the NRC and the Project stakeholders, including states, Indian tribes, and local communities and land owners, to complete the Project in a timely and cost-effective manner consistent with ER priorities.

Still in its formative stage, the Project will incorporate the following:

- The pending approval of the UMTRA Ground Water programmatic environmental impact statement (PEIS) (the guiding National Environmental Policy Act [NEPA] document for the Project), and the record of decision (ROD) specifying the preferred alternative for conducting the Project.

- Recommendations from an independent technical review (ITR) team that identified costeffective, quality, customer-oriented ways to improve the Project. 
- Project management transition from DOE-Albuquerque (AL) to DOE-GJPO during fiscal year (FY) 1996.

- Project contract support transition from the current DOE-AL contractor to the two DOEGJPO performance-based task order contractors scheduled for award by 30 June 1996.

- Development of a model Project cooperative agreement that will establish the framework for DOE's relationship with states and tribes.

The Project has two major milestones: 1) completion of site assessments by FY1999, and 2) completion of required ground water compliance actions no later than FY 2014.

\section{$1.1 \quad$ PURPOSE OF MANAGEMENT ACTION PROCESS}

The Project management action process (MAP) will foster common ground and consensus-building among the federal, state, tribal, and local participants by providing the following in a single, updated document:

- The status of the Project, including accomplishments and progress achieved.

- A strategy for successful completion of the Project.

- The requirements summary, presenting schedules and costs of both completed and uncompleted activities.

- The identification of Project improvement and optimization opportunities.

- A tool for prioritizing and sequencing work activities.

- A forum for identifying and working through any technical, administrative, or regulatory issues that could impede or enhance the effective, on-schedule performance of compliance strategy implementation.

- A vehicle for evaluating compliance alternative strategies and summarizing Project and site-specific decisions.

\subsection{ORGANIZATION OF THE MAP DOCUMENT}

This MAP document is organized into the following sections:

Section 1 - Summarizes the current status of the Project, and defines the mission, objectives, and major milestones of the Project. Describes the purpose of the MAP, organization of the document, and the strategies for implementation of the MAP. This section also identifies key participants and relationships between the UMTRA Ground Water Project and the related but separate UMTRA Surface Project, as well as between the DOE, the NRC, and the stakeholders. 
Section 2 - Summarizes the sites' characteristics, including local and regional land use setting, and social, economic, cultural, and ecological factors influencing the sites. Site-specific information on surface remedial action and ground water contamination is provided also. The section includes a table of environmental conditions of the sites, site maps showing extent of contamination in ground water, and a table listing those principal constituents of concern at each site.

Section 3 - Summarizes the current status of the sites' ER progress and accomplishments, regulatory compliance, and waste management and material disposition activities. The section describes the status of the public involvement process (PIP) and the management efforts related to integration of the Project considerations highlighted in the introduction.

Section 4 - Presents qualitative relative risks for each site using two separate ranking methodologies performed by DOE in 1991 and in 1996, and one recommended by the ITR team in 1995.

Section 5 - Describes the proposed action documented in the PEIS, and presents critical performance criteria for measuring the success of the Project in implementing the strategy. The Project is evaluating this approach in light of the recent ITR recommendations addressed in Section 7.

Section 6 - Contains the Project master schedule, which is based upon the proposed FY1998 field budget.

Section 7 - Identifies the specific technical and administrative issues facing the Project, and addresses the major ITR recommendations.

Appendix A - Summarizes past cost and projected budget information for restoration and compliance actions based on the FY1998 proposed field budget subject to DOE Headquarters (HO) approval.

Appendix B - Lists major ER documents relevant to the Project.

Appendix C - Describes approved and/or pending decision documents.

Appendix D - Presents four site conceptual models depicting upper-most aquifer contaminants, transport mechanisms, and potential exposure pathways and receptors for sites with high relative risks based on the 1991 prioritization shown in Section 4.0.

Appendix E - Summarizes Project controls for the program.

Figures follow the text in each section, as needed. 


\subsection{ENVIRONMENTAL RESTORATION OBJECTIVES}

The mission of the Project is to eliminate or reduce to acceptable levels the potential health and environmental consequences of milling activities by meeting EPA ground water standards set forth in 40 CFR Part 192, Subpart B. This is required, in concert with the UMTRA Surface Project cleanup work nearing completion, to allow final NRC concurrence that each processing site is fully compliant with all environmental regulations and protective of human health and the environment.

The prime objective of the Project is to select and implement ground water compliance strategies at each site (including appropriate interim actions) to protect human health and the environment and to fully comply with the EPA ground water cleanup standards in a cost-effective and timely manner. The Project objective will be accomplished when the NRC concurs with DOE ground water compliance activities at each site.

The secondary Project objectives include:

- Health and safety objectives

- Conduct Project activities in a safe and environmentally sound manner in accordance with OSHA, EPA standards, and applicable federal, tribal, and state laws.

- Implement compliance strategies, including any interim actions or institutional controls required in the near term, to ensure that contaminated ground water is not used for inappropriate purposes.

- Regulatory objectives

- Satisfy NEPA provisions (42 USC $\$ 4321$ et seq.), as implemented by the Council on Environmental Quality regulations (40 CFR Parts 1500-1508) and DOE guidelines.

- Obtain NRC concurrence that compliance with ground water standards has been achieved, per the requirements of 40 CFR Part 192, at processing sites where tailings have been relocated to an off-site disposal cell.

- Complete 40 CFR Part 192 ground water compliance activities at processing sites where surface contamination has been stabilized in place or on the site to facilitate the two-step NRC licensing of the site per the requirements of 10 CFR $\$ 40.27$. 
- Public involvement objectives

- Conduct a public participation program to encourage stakeholder awareness, understanding, participation, input, and support in the Project decision-making process.

- Maintain a proactive public affairs and community relations program which includes accurate and timely information of public/media interest.

- Foster cooperation between the DOE and affected stakeholders to successfully accomplish the Project mission in a mutually satisfactory manner.

- Establish required Project cooperative agreements with states and tribes by the end of FY1997.

- Project management objectives

- Complete the Project under budget. The projected federal total estimated costs (TEC) for the Project is $\$ 494.2$ million (M) based on the FY 1997 field budget. The DOE-GJPO FY 1998 proposed field budget TEC is $\$ 308.5 \mathrm{M}$. This more recent projected budget TEC is approximately 62 percent of the FY1997 budget TEC. A major portion of this proposed reduction is a result of changes to the Project schedule to more closely reflect the ITR recommendations to accelerate active remediation and a reduction in base administrative costs due to movement of the Project to GJPO.

- Complete the Project by FY2014 or earlier. The FY1997 budget reflects an end date of FY2014. However, as mentioned above, the FY1998 proposed field budget is based upon a more aggressive schedule whereby the Project end data has been moved up to FY2011. This accelerated schedule is contingent upon obtaining required funding levels, consensus building with stakeholders, and resolution of technical and programmatic issues.

- Work with NRC and stakeholders to apply programmatic controls and achieve compliance in a cost-effective and expeditious manner.

- Review and implement, as necessary, the recommendations of the ITR team to the greatest extent practical to further reduce costs and schedule to meet the Project objectives.

- Transition contractor support from the DOE-AL contractor, Jacobs Engineering Group Inc., to the new DOE-GJPO contractors. GJPO is currently undergoing selection of two separate performance-based task order contracts which it intends to award by 30 June 1996. The 
Technical Assistance and Remediation (TAR) contractor will assist GJPO in conducting its evaluation and remediation project activities for the Project. The Facility Operations and Support (FOS) contractor will maintain the GJPO site, operate on-site laboratories, and support training and other administrative elements.

\subsection{ACCOMPLISHMENTS}

Activities accomplished through the date of this document and activities planned for the remainder of FY1996 are described below.

\subsubsection{Activities accomplished}

- Baseline risk assessments - Site-specific baseline risk assessments (BLRA), quantifying human and environmental exposures to the site contaminants of concern, have been performed at 20 sites. The BLRAs for Slick Rock and Rifle cover two sites each. Fifteen final BLRA documents, incorporating DOE review, have been distributed to the public (see Appendix B).

- Site observational work plans - Draft site observational work plans (SOWP) have been prepared for 11 sites. The SOWP for Rifle covers two sites (Appendix B).

- Programmatic environmental impact statement - The public has submitted comments to the draft PEIS. Responses to the public comments have been completed, changes made to the PEIS based on these comments, and the document is presently undergoing DOE-HQ and NEPA cooperating agency (NRC, Hopi Tribe, and Navajo Nation) review.

- Decision documents - The final Lowman, Idaho, UMTRA Surface Project RAP declared that no ground water contamination was evidenced to have resulted from the past activities at the site and that no further UMTRA Ground Water Project action was required for NRC to complete licensing requirements.

- Cooperative agreements - A model Project cooperative agreement is approximately 85 percent complete. This model will be used as a framework to work with individual states and tribes to complete the cooperative agreements by the end of FY1997.

- Transition - Authority for management of the Project was transferred from DOE-AL to DOE-GJPO 1 October 1995. The core team of GJPO government and contract support personnel has been assembled to continue the Project work until the new GJPO TAR contract is in place and the TAR contractor is transitioned onto the site in the July-August 1996 timeframe. 


\subsubsection{Scheduled for completion in FY1996}

- Accomplish major revision of Project by completing evaluation and implementation of ITR recommendations.

- Complete Project transition to GJPO and its TAR and FOS contractors.

- Complete Project PEIS and ROD.

- Complete all site BLRAs.

- Complete development of initial versions of SOWPs.

- Initiate environmental assessments (EA) (site-specific NEPA documents that tier off the PEIS| at two sites.

- Complete the Spook, Wyoming, site EA and initiate the RAP.

- Negotiate with states and tribes regarding ground water interim actions at the Rifle, Colorado, and Riverton, Wyoming, sites.

- Initiate a pilot plant study at the Tuba City, Arizona, site.

\subsection{PROJECT TEAM}

The Project Team is in transition during FY1996. Beginning in FY1996 the Project was transferred to DOE-GJPO, after being managed from the UMTRA Project Office in Albuquerque, New Mexico (DOE-AL), from its inception through FY1995. The original support contractor for the Project, Jacobs Engineering Group Inc., will remain through 31 March 1996. At that time, a core group of DOE-GJPO government and contract support personnel will continue to achieve the Project objectives until the new GJPO TAR and FOS contracts are in place later in FY1996. Table 1.5-1 lists core team members and key participants.

\subsection{ORGANIZATIONAL INTERFACES}

Figure 1.6-1 lists organizational interfaces. Table 1.6-1 shows the roles and responsibilities of each organization.

\subsection{STATUS OF MANAGEMENT ACTION PROCESS}

The Project is presently in a formative stage, integrating major considerations arising from 1) the pending PEIS approval and ROD determinations; 2) the recent ITR recommendations; 3) the FY1996 Project management transition to DOEGJPO; 4) the ongoing Project contract support transition to the new DOE-GJPO contractors; 5) identification of any appropriate interim actions; and 6) establishment of cooperative agreements with states and tribes. 
Table 1.5-1 Project team

\begin{tabular}{|c|c|c|c|}
\hline Organization & Name & Role/responsibility & Phone \\
\hline DOE & Jim Lampley & $\begin{array}{l}\text { Grand Junction Projects Office } \\
\text { Manager }\end{array}$ & $19701248-6000$ \\
\hline $\begin{array}{l}\text { CORE TEAM } \\
\text { DOE } \\
\text { DOE }\end{array}$ & $\begin{array}{l}\text { Paul Beam } \\
\text { Ray Plieness }\end{array}$ & $\begin{array}{l}\text { HQ Program Manager } \\
\text { UMTRA Ground Water Project } \\
\text { Manager }\end{array}$ & $\begin{array}{l}(310) 903-8133 \\
(970) 248-6091\end{array}$ \\
\hline $\begin{array}{l}\text { DOE } \\
\text { DOE } \\
\text { Contractor } \\
\text { Contractor } \\
\text { Contractor } \\
\text { Contractor } \\
\text { Contractor }\end{array}$ & $\begin{array}{l}\text { Don Metzler } \\
3 \text { FTEs (TBD) } \\
\text { Sam Marutsky } \\
\text { Mark Kautsky } \\
\text { Dave Donohue } \\
\text { Randy Juhlin } \\
\text { Stan Morrison }\end{array}$ & $\begin{array}{l}\text { Technical Lead } \\
\text { Site Managers } \\
\text { Project Manager } \\
\text { Project Hydrologist } \\
\text { Project Hydrologist } \\
\text { Project Engineer } \\
\text { Project Geochemist }\end{array}$ & $\begin{array}{l}(970) 248-7612 \\
(970) 248-6059 \\
(970) 248-6556 \\
(970) 248-6551 \\
(970) 248-6502 \\
(970) 248-6373\end{array}$ \\
\hline $\begin{array}{l}\text { MATRIX SUPPORT } \\
\text { DOE } \\
\text { DOE } \\
\text { DOE } \\
\text { DOE } \\
\text { DOE }\end{array}$ & $\begin{array}{l}\text { Audrey Berry } \\
\text { Bo Kim } \\
\text { Gail Wiesner } \\
\text { Chris Pennal } \\
\text { Dale Christian }\end{array}$ & $\begin{array}{l}\text { Public Affairs } \\
\text { Health and Safety } \\
\text { Budget Analyst } \\
\text { Program Analyst } \\
\text { NEPA Compliance Manager }\end{array}$ & $\begin{array}{l}(970) 248-7727 \\
(970) 248-7620 \\
(970) 248-6010 \\
(970) 248-6011 \\
(970) 248-6079\end{array}$ \\
\hline $\begin{array}{l}\text { STAKEHOLDERS } \\
\text { Arizona Radiation } \\
\text { Regulatory Agency } \\
\text { Colorado Department } \\
\text { of Public Health and } \\
\text { Environment }\end{array}$ & $\begin{array}{l}\text { Aubrey Godwin } \\
\text { Jeff Deckler }\end{array}$ & $\begin{array}{l}\text { Arizona Representative } \\
\text { Colorado Representative }\end{array}$ & $\begin{array}{c}(602) 255-4845 \text { ext. } \\
222 \\
(303) 693-3387\end{array}$ \\
\hline $\begin{array}{l}\text { Remediation Bureau } \\
\text { Division of } \\
\text { Environmental Quality }\end{array}$ & Dean Nygard & Idaho Representative & $(208) 334-5860$ \\
\hline $\begin{array}{l}\text { Hazardous and } \\
\text { Radioactive Materials } \\
\text { Bureau }\end{array}$ & Norma Silva & New Mexico Representative & $(505) 827-1557$ \\
\hline $\begin{array}{l}\text { Environmental } \\
\text { Engineering Division }\end{array}$ & Dana Mount & North Dakota representative & $(701) 328-5200$ \\
\hline $\begin{array}{l}\text { Oregon DOE } \\
\text { Department of } \\
\text { Environmental } \\
\text { Protection }\end{array}$ & $\begin{array}{l}\text { Mary Lou Blazek } \\
\text { James G. Yusko }\end{array}$ & $\begin{array}{l}\text { Oregon Representative } \\
\text { Pennsylvania Representative }\end{array}$ & $\begin{array}{l}(503) 378-5544 \\
(412) 442-4000\end{array}$ \\
\hline $\begin{array}{l}\text { Texas Natural } \\
\text { Resource Conservation } \\
\text { Commission }\end{array}$ & Alice Rodgers & Texas Representative & $(512) 239-6846$ \\
\hline $\begin{array}{l}\text { Utah Department of } \\
\text { Environmental Quality }\end{array}$ & William Sinclair & Utah Representative & $(801) 536-4250$ \\
\hline $\begin{array}{l}\text { Land Quality Division } \\
\text { Office of Mining and } \\
\text { Mineral Resources }\end{array}$ & $\begin{array}{l}\text { Rick Chancellor } \\
\text { Norman Honie }\end{array}$ & $\begin{array}{l}\text { Wyoming Representative } \\
\text { Hopi Tribal Representative }\end{array}$ & $\begin{array}{l}(307) 777-7756 \\
(520) 734-2441\end{array}$ \\
\hline $\begin{array}{l}\text { Division of Resources } \\
\text { Northern Arapaho- } \\
\text { Shoshone Tribes }\end{array}$ & $\begin{array}{l}\text { Bernadine Martin } \\
\text { Don Aragon }\end{array}$ & $\begin{array}{l}\text { Navajo Nation Representative } \\
\text { Shoshone-Arapaho Tribes } \\
\text { Representative }\end{array}$ & $\begin{array}{l}(520) 871-6982 \\
(307) 332-3164\end{array}$ \\
\hline
\end{tabular}


Table 1.6-1 Organization functions

\begin{tabular}{|c|c|}
\hline Name of organization & Role/responsibility \\
\hline DOE HQ & Funding and overall Project guidance. \\
\hline DOE-AL & $\begin{array}{l}\text { GJPO funding and support, direction to implement Project } \\
\text { guidance. }\end{array}$ \\
\hline DOE-GJPO core team & $\begin{array}{l}\text { Project management and implementation, develop and } \\
\text { implement compliance strategies and Project scope, oversee } \\
\text { contracts, establish milestones and stakeholder agreements, } \\
\text { public interface. }\end{array}$ \\
\hline $\begin{array}{l}\text { GJPO TAR and FOS } \\
\text { contractors }\end{array}$ & $\begin{array}{l}\text { Provides technical and management staff to perform Project } \\
\text { activities as tasked. }\end{array}$ \\
\hline NRC & Provides regulatory oversight. \\
\hline EPA & Establishes compliance and remediation standards. \\
\hline Bureau of Reclamation & $\begin{array}{l}\text { Provide independent reviews, technical assistance, and } \\
\text { execution of program activities as tasked. }\end{array}$ \\
\hline $\begin{array}{l}\text { DOE-Sandia National } \\
\text { Laboratories }\end{array}$ & $\begin{array}{l}\text { Provide independent reviews, technical assistance, and } \\
\text { execution of program activities as tasked. }\end{array}$ \\
\hline Indian tribes and states & $\begin{array}{l}\text { Participate in Project activities, review and comment on } \\
\text { documents, implement institutional controls, provide } \\
\text { stakeholder consideration, and other responsibilities as will } \\
\text { be outlined in model cooperative agreement under } \\
\text { development. }\end{array}$ \\
\hline
\end{tabular}

The MAP provides an efficient and comprehensive means for DOE to provide direction at this formative stage, and throughout the remainder of the Project lifecycle, to ensure successful attainment of the Project objectives.

Annual MAP document updates will occur in January unless DOE-AL or DOE-HQ direct otherwise.

\subsection{STRATEGY FOR MANAGEMENT ACTION PROCESS}

The Project team will meet regularly to review the Project's progression through the MAP. Individual issues as well as the overall strategy will be addressed. As directed in the MAP guidance document, the Project has completed step 1, "The Development of the Straw Document," and step 2, "The Identification of The Project Team" (DOE, 1996).

Step 3, "Project Review," will be largely centered around the recent ITR. The responses to this team's report have been developed as part of the MAP and, when coupled with the ITR report, will serve as the basis for the Project review. 
Step 4, "Compile and Adopt Recommendations," will be documented in the response to the ITR report as incorporated into the draft MAP document.

Step 5, "Assemble and Write Your MAP Document," has proceeded to the generation of this draft MAP document, which proposes approaches for resolving issues. The final document will be prepared later this spring after NRC and stakeholder comments have been received.

Step 6, "Execution of Process and Maintenance of the MAP document," will be performed by the core group who will review and summarize the status of the Project to ensure key issues are resolved in a timely manner. This group will identify those issues and propose solutions for annual MAP document updates. 


\section{Figure 1.0-1}

Site Location Map

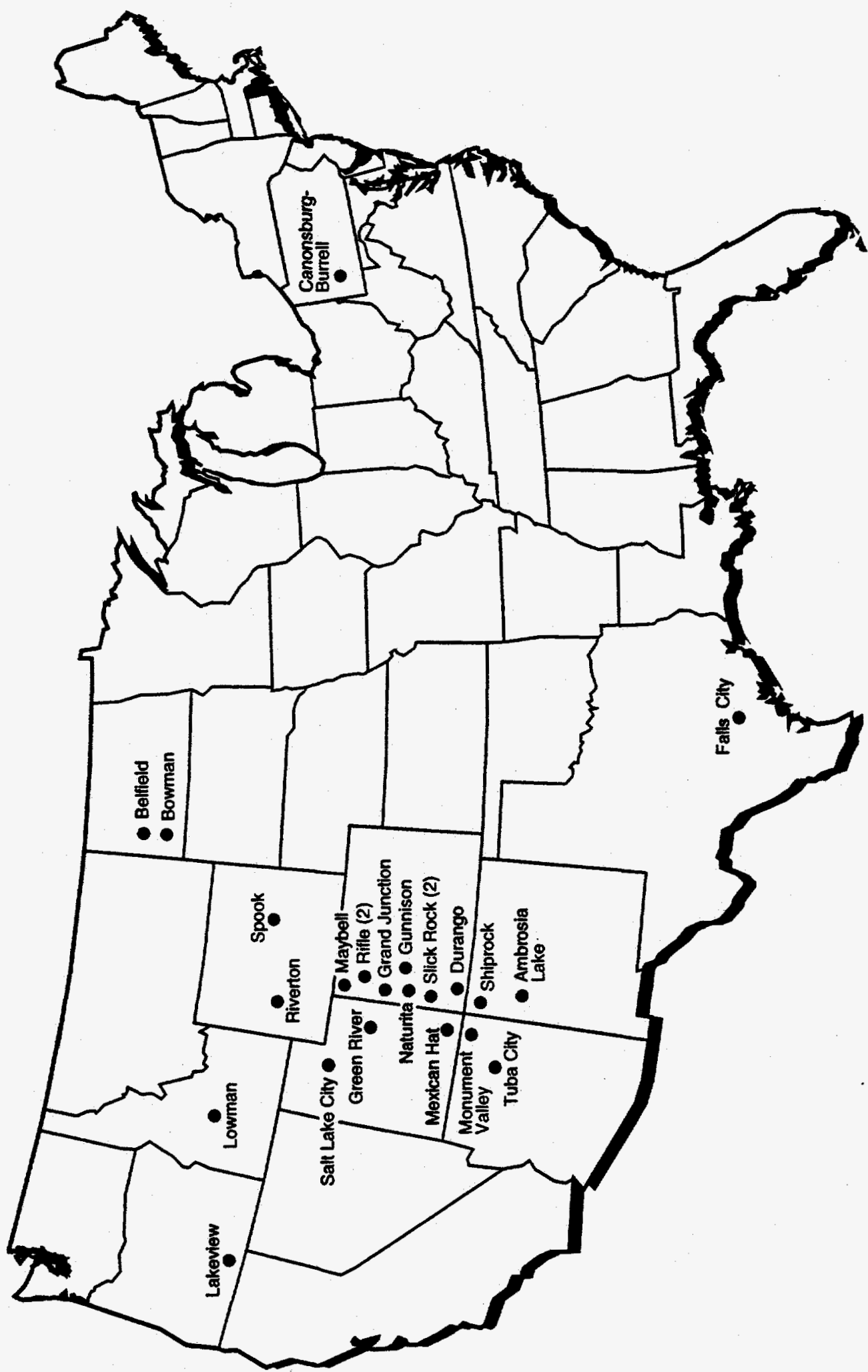




\section{Figure 1.6-1}

\section{Organizational Interfaces}

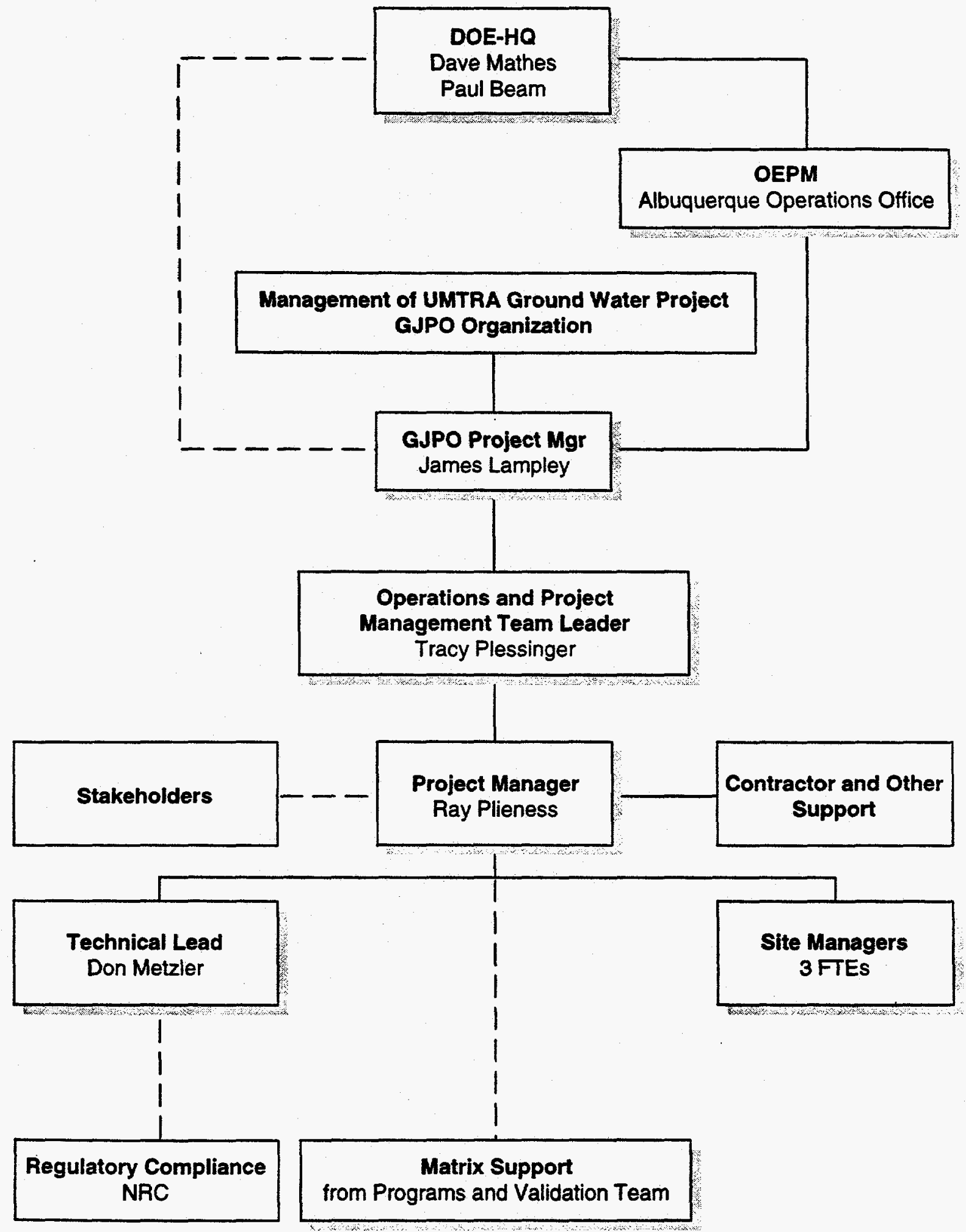




\subsection{SITE DESCRIPTIONS AND COMPREHENSIVE PLANNING}

\subsection{OPERATIONAL HISTORY}

The 24 sites designated under Title I of the UMTRCA were active in the production of uranium for use by the AEC from the 1940's through the 1970's. The sites received ore from a variety of sources and provided various concentrates of uranium to the AEC. The DOE commenced the cleanup of surface contamination at the UMTRA sites beginning with Canonsburg, Pennsylvania, in 1983 and will conclude processing site surface cleanup activities when the Naturita, Colorado, site is complete in 1997.

In an amendment to the UMTRCA, DOE was authorized to perform ground water remediation at the designated processing sites without a time limitation. Congress also directed DOE to comply with EPA standards (40 CFR Part 192). The final EPA ground water standards pertinent to the Project were published on 11 January 1995 (60 FR 2854). DOE intends to complete implementation of all required compliance strategies at the UMTRA sites, addressing any human health and environmental risks associated with the cumulative estimated 10 billion gallons (gal) (3.8 billion liters [L]) of contaminated ground water, no later than FY2014 to facilitate subsequent NRC licensing of the sites.

The UMTRA Surface Project removed or encapsulated the bulk of the source term contributing to ground water contamination at the processing sites. The tailings and other residual radioactive materials (RRM) were disposed of in one of three methods, based on site-specific considerations. Summarized below is the relationship between the UMTRA Surface Project disposal methods and the NRC licensing procedures, which together define the requirements of the follow-on UMTRA Ground Water Project at the processing sites.

One-step licensing by the NRC - Relocated sites are processing sites from which tailings and RRM are removed to an off-site disposal cell. Off-site disposal cells (not the processing sites) are licensed by the NRC soon after closure. However, compliance with EPA ground water standards at the processing sites requires NRC concurrence.

Two-step licensing by the NRC - Stabilized in place (SIP) sites are processing sites at which tailings and RRM were left in place, contoured, and covered; stabilized on site (SOS) sites are processing sites at which tailings and RRM have been moved to another location within the original site boundary. Licensing at these sites involves initial NRC acceptance of the long-term care program for the surface remedial action at these processing sites, with subsequent DOE verification and NRC concurrence that ground water compliance has been met.

Table 2.1-1 lists surface remedial action data (dates of completion, disposal option, acreage, and volumes of contaminated materials) and the amount of existing contaminated ground water for the 24 UMTRA Project sites. 
Table 2.1-1 History of Project operation

\begin{tabular}{|c|c|c|c|c|c|c|c|c|}
\hline \multirow{2}{*}{ 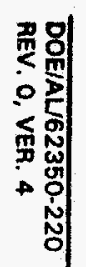 } & \multicolumn{7}{|c|}{ UMTRA Surface Project data } & \\
\hline & UMTRA project site & $\begin{array}{l}\text { Processing site } \\
\text { remedial action } \\
\text { completion date } \\
\end{array}$ & $\begin{array}{c}\text { On-site } \\
\text { disposal } \\
\text { (SIP/SOS) }\end{array}$ & $\begin{array}{c}\text { Off-site } \\
\text { disposal } \\
\text { (relocated) }\end{array}$ & $\begin{array}{c}\text { Cubic yards of } \\
\text { contaminated material } \\
\text { (thousands) }\end{array}$ & $\begin{array}{c}\text { Contaminated } \\
\text { land (acres) } \\
\end{array}$ & $\begin{array}{l}\text { Estimated amount of } \\
\text { contaminated ground water } \\
\text { (millions of gallons) }\end{array}$ & \\
\hline & $\begin{array}{l}\text { Monument Valley, AZ } \\
\text { Tuba City, AZ }\end{array}$ & $\begin{array}{l}3-94 \\
5-90\end{array}$ & $\sqrt{ }$ & $\sqrt{ }$ & $\begin{array}{r}925 \\
1,631\end{array}$ & $\begin{array}{r}83 \\
327\end{array}$ & $\begin{array}{r}1,200 \\
780\end{array}$ & \\
\hline & Durango, CO & 5-91 & & $\sqrt{ }$ & 2,533 & 127 & 100 & \\
\hline & Grand Junction, CO & $8-94$ & & $\sqrt{ }$ & 4,425 & 114 & 330 & \\
\hline & Gunnison, CO & $12-95$ & & $\sqrt{ }$ & 796 & 68 & 1,900 & \\
\hline & Maybell, CO & $12-96^{b}$ & $\sqrt{ }$ & & 4,100 & 214 & 230 & \\
\hline & Naturita, CO & $9-97^{b}$ & & $\sqrt{ }$ & 399 & 247 & 100 & \\
\hline & Old Rifle, co & $7-96^{b}$ & & $\sqrt{ }$ & 661 & 88 & 70 & \\
\hline & New Rifle, CO & $7-96^{b}$ & & $\sqrt{ }$ & 3,096 & 238 & 600 & \\
\hline & Slick Rock, CO (UC) & $12 / 96^{b}$ & & $\sqrt{ }$ & 547 & 92 & 26 & \\
\hline & Slick Rock, CO (NC) & $12 / 96^{b}$ & & $\sqrt{ }$ & 85 & 47 & 12 & \\
\hline & Lowman, ID & $6-92$ & $\sqrt{ }$ & & 126 & 30 & 0 & \\
\hline & Ambrosia Lake, NM & $6-95$ & $\sqrt{ }$ & & 5,162 & 612 & $320^{\circ}$ & \\
\hline & Shiprock, NM & $9-86$ & $\sqrt{ }$ & & 2,800 & 130 & 160 & \\
\hline & Belfield, ND & $N / A^{d}$ & & & 58 & 31 & 4.7 & \\
\hline & Bowman, ND & $N / A^{d}$ & & & 100 & 71 & 58 & \\
\hline & Lakeview, OR & $10-89$ & & $\sqrt{ }$ & 944 & 116 & 1,200 & \\
\hline & Canonsburg, $\mathbf{P A}^{\mathbf{B}}$ & $12-85$ & $\sqrt{ }$ & & 265 & 79 & 5.3 & $\stackrel{n}{7}$ \\
\hline & Falls City, TX & $7-94$ & $\sqrt{ }$ & & 6,019 & 593 & 1,200 & \\
\hline & Green River, UT & $12-89$ & $\sqrt{ }$ & & 382 & 48 & 180 & \\
\hline & Mexican Hat, UT & 2.95 & $\sqrt{ }$ & & 2,558 & 250 & $110^{c}$ & \\
\hline & Salt Lake City, UT & $6-89$ & & $\sqrt{ }$ & 2,710 & 128 & 350 & \\
\hline & Riverton, WY & $9-90$ & & $\sqrt{ }$ & 1,793 & 140 & 500 & \\
\hline & Spook, WY & $9-89$ & $\sqrt{ }$ & & 315 & 21 & 1,000 & \\
\hline & Total & & 10 & 12 & 42,430 & 3894 & 10,436 & \\
\hline 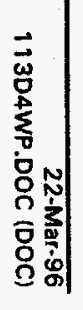 & $\begin{array}{l}\text { From TAC, } 1995 \text {, } \\
\text { "Anticipated completion date. } \\
\text { 'Areas of saturation of contaminate } \\
\text { 'The designated uranium mill sites a } \\
\text { to remediate the sites. } \\
\text { Encludes Burrell, Pennsylvania, vicin } \\
\text { Note: This table represents the ope } \\
\text { UC. Union Carbide. }\end{array}$ & $\begin{array}{l}\text { ter in geological format } \\
\text { d Bowman, North Dako } \\
\text { disposal cell volume an } \\
\text { UMTRA Project reme }\end{array}$ & $\begin{array}{l}\text { Is beneath the s } \\
\text { will not be rem } \\
\text { I action. }\end{array}$ & $\begin{array}{l}\text { site that previou } \\
\text { lediated by DOE } \\
\text { 5. The sites are }\end{array}$ & $\begin{array}{l}\text { sly did not contain ground water. } \\
\text { because the state of North Da } \\
\text { listed in alphabetical order by } s\end{array}$ & $\begin{array}{l}\text { cota has declined to } \\
\text { tate. }\end{array}$ & ovide its statutorily required cost-share & 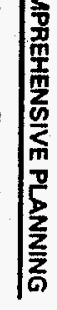 \\
\hline
\end{tabular}

NC. - North Continent 


\subsection{ENVIRONMENTAL SETTING}

The 24 Title / sites are located in 10 states (Figure 1.0-1) and 4 tribal lands. Table 2.2-1 lists the key features of the environmental setting of the processing sites.

Past processing site operations have resulted in ground water contamination. EPA has established maximum concentration limits $(M C L)$ for certain hazardous constituents in ground water contaminated by uranium processing. Table 2.2-2 lists the constituents that have exceeded MCLs for each site. Figures 2.1-1 through -21 show the extent of contaminant migration at processing sites as demonstrated by the concentrations of indicator constituents in ground water. Site-specific UMTRA Surface Project RAPs and UMTRA Ground Water Project BLRAs and SOWPS contain details on the environmental settings.

\subsection{CURRENT SITE AND ADJACENT LAND USES}

A portion of the SIP and SOS sites' current and future use is restricted due to the siting of the disposal cell which resulted from the surface cleanup. Access to these sites is restricted. At relocated sites the goal is to release the former processing site for unrestricted use. One site (Grand Junction, Colorado) has been returned to the local community for the development of a park. The other sites will be returned to the Indian tribe, private property holder, or state. Currently, private properties adjacent to the site under which the contaminated ground water plumes have migrated have no institutional or engineering controls in place to ensure that inappropriate ground water use does not occur. The current land uses at the sites and surrounding areas are provided in Table 2.2-1.

\subsection{FACILITIES, INFRASTRUCTURE, AND EQUIPMENT}

The Project does not possess any facilities, infrastructure, or equipment as envisioned in the guidance document. Minimal equipment in the form of automatic data processing has been purchased by the Project. Water sampling equipment, vehicles, and supplies are being transferred from the UMTRA Surface Project to the GJPO and will be available to support the Project.

\subsection{INFLUENCING FACTORS}

There are numerous factors which may potentially influence the planning and implementation of the Project:

These factors include:

- Economic factors - The UMTRA Ground Water Project will provide less benefit to local economies than the UMTRA Surface Project. By removing a local nuisance and potential health hazard (the tailings sites) and creating numerous construction jobs, the UMTRA Surface Project served as an economic stimulus to many of the communities affected. Community 


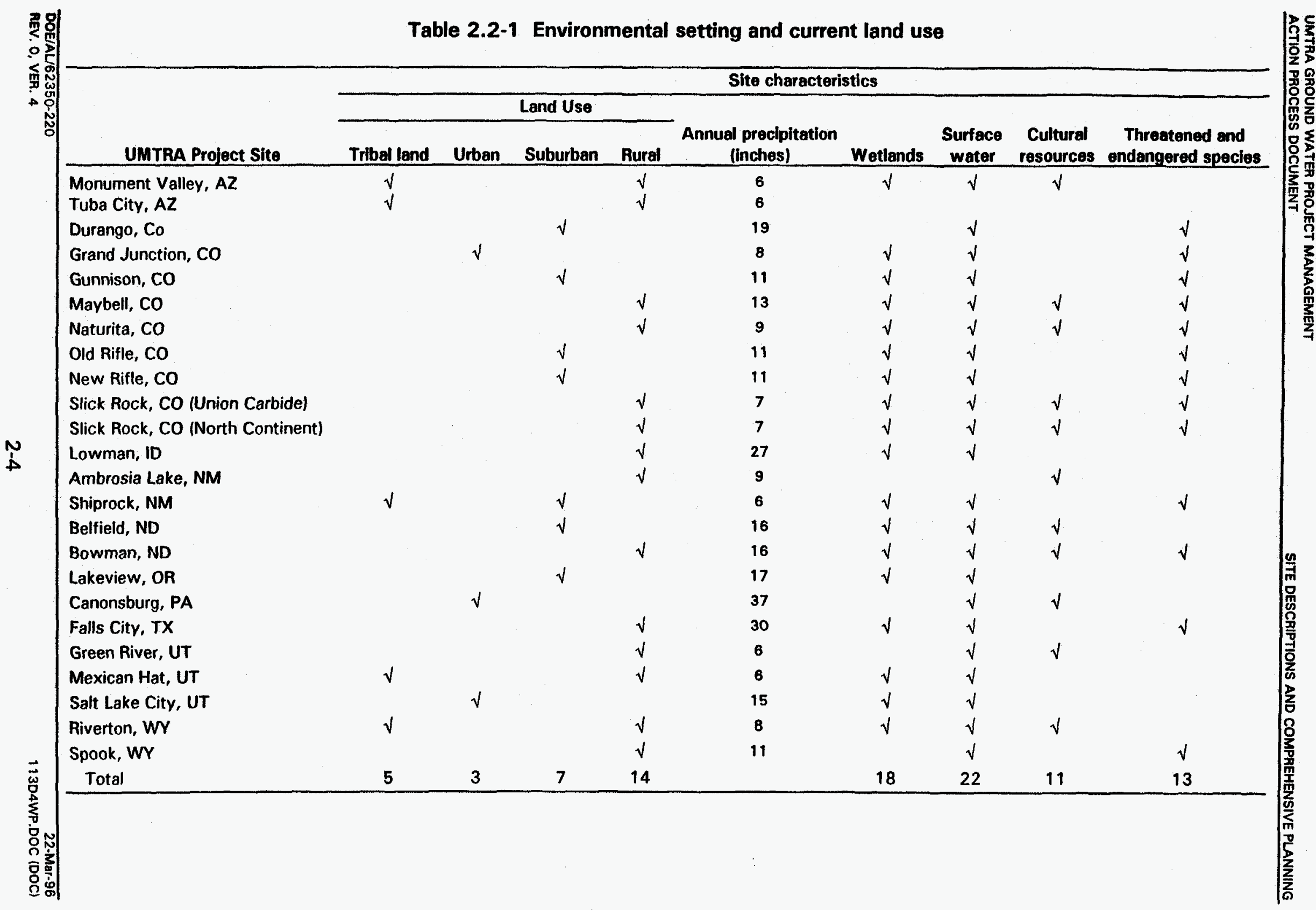


Table 2.2-2 Environmental condition of property

\begin{tabular}{|c|c|c|c|c|c|c|c|c|c|c|c|c|c|}
\hline \multirow[b]{2}{*}{ UMTRA Project site } & \multirow[b]{2}{*}{$\begin{array}{l}\text { Off-site } \\
\text { migration }\end{array}$} & \multicolumn{12}{|c|}{ Constituents exceeding maximum concentration limits } \\
\hline & & Arsonic & Cadmium & Chromium & Lead & Mercury & Molybdenum & $\begin{array}{c}\text { Not gross } \\
\text { alphe }\end{array}$ & Nitrate & $\begin{array}{l}\text { Radium- } \\
226 / 228 \\
\end{array}$ & Solonium & Silver & Uranlum \\
\hline Monument Valley, $A Z$ & $\sqrt{ }$ & & & & & & & $\sqrt{ }$ & $\sqrt{ }$ & $\sqrt{ }$ & & & $\sqrt{ }$ \\
\hline Tuba City, AZ & $\sqrt{ }$ & & & & & & $\sqrt{ }$ & $\sqrt{ }$ & $\sqrt{ }$ & $\sqrt{ }$ & $\sqrt{ }$ & & $\sqrt{ }$ \\
\hline Durango, CO & & & $\sqrt{ }$ & & $\sqrt{ }$ & & $\sqrt{ }$ & $\sqrt{ }$ & & $\sqrt{ }$ & $\sqrt{ }$ & & $\sqrt{ }$ \\
\hline Grand Junction, CO & $\sqrt{ }$ & & & & & & $\sqrt{ }$ & $\sqrt{ }$ & & & & & $\sqrt{ }$ \\
\hline Gunnison, CO & $\sqrt{ }$ & & & & & & & $\sqrt{ }$ & & $\sqrt{ }$ & & & $\sqrt{ }$ \\
\hline Maybell, CO & & $\sqrt{ }$ & $\sqrt{ }$ & & & & $\sqrt{ }$ & $\sqrt{ }$ & $\sqrt{ }$ & $\sqrt{ }$ & $\sqrt{ }$ & & $\sqrt{ }$ \\
\hline Naturita, $\mathrm{CO}$ & $\sqrt{ }$ & $\sqrt{ }$ & & & & & $\sqrt{ }$ & $\sqrt{ }$ & & $\sqrt{ }$ & $\sqrt{ }$ & & $\sqrt{ }$ \\
\hline Old Rifle, CO & $\sqrt{ }$ & $\sqrt{ }$ & & & & & $\sqrt{ }$ & $\sqrt{ }$ & & $\sqrt{ }$ & $\sqrt{ }$ & & $\sqrt{ }$ \\
\hline New Rifle, CO & $\sqrt{ }$ & $\sqrt{ }$ & $\sqrt{ }$ & & & & $\sqrt{ }$ & $\sqrt{ }$ & $\sqrt{ }$ & $\sqrt{ }$ & $\sqrt{ }$ & & $\sqrt{ }$ \\
\hline $\begin{array}{l}\text { Slick Rock, CO (Union } \\
\text { Carbide) }\end{array}$ & $\sqrt{ }$ & & & & & & $\sqrt{ }$ & $\sqrt{ }$ & $\sqrt{ }$ & $\sqrt{ }$ & $\sqrt{ }$ & & $\sqrt{ }$ \\
\hline $\begin{array}{l}\text { Slick Rock, CO (North } \\
\text { Continent) }\end{array}$ & $\sqrt{ }$ & & & & & & & $\checkmark$ & & $\sqrt{ }$ & & & $\sqrt{ }$ \\
\hline Lowman, ID' & N/A & & & & & & & & & & & & \\
\hline Ambrosia Lake, NM & $\sqrt{ }$ & & & & & & $\sqrt{ }$ & $\sqrt{ }$ & $\sqrt{ }$ & & $\sqrt{ }$ & & $\sqrt{ }$ \\
\hline Shiprock, NM & $\sqrt{ }$ & & $\sqrt{ }$ & & & & & $\sqrt{ }$ & $\sqrt{ }$ & $\sqrt{ }$ & $\sqrt{ }$ & & $\sqrt{ }$ \\
\hline Belfield, ND ${ }^{b}$ & N/A & & & & & & & & & & & & \\
\hline Bowman, ND $^{b}$ & N/A & & & & & & & & & & & & \\
\hline Lakeview, OR & $\sqrt{ }$ & $\sqrt{ }$ & & & & & $\sqrt{ }$ & $\sqrt{ }$ & & & & & \\
\hline Canonsburg, PA & & & & & & & & $\sqrt{ }$ & & & & & $\sqrt{ }$ \\
\hline Falls City, TX & $\sqrt{ }$ & $\sqrt{ }$ & $\sqrt{ }$ & $\sqrt{ }$ & $\sqrt{ }$ & $\sqrt{ }$ & $\sqrt{ }$ & $\sqrt{ }$ & $\sqrt{ }$ & $\sqrt{ }$ & $\sqrt{ }$ & & $\sqrt{ }$ \\
\hline Green River, UT & $\sqrt{ }$ & & & & & & $\sqrt{ }$ & $\sqrt{ }$ & $\sqrt{ }$ & $\sqrt{ }$ & $\sqrt{ }$ & & $\sqrt{ }$ \\
\hline Mexican Hat, UT & $\sqrt{ }$ & $\sqrt{ }$ & & $\sqrt{ }$ & & & & $\sqrt{ }$ & & & & & \\
\hline Salt Lake City, UT & $\sqrt{ }$ & & & & & & $\sqrt{ }$ & $\sqrt{ }$ & & & & & $\sqrt{ }$ \\
\hline Riverton, WY & $\sqrt{ }$ & & & & $\sqrt{ }$ & & $\sqrt{ }$ & $\sqrt{ }$ & & $\sqrt{ }$ & & & $\sqrt{ }$ \\
\hline Spook, WY & $\sqrt{ }$ & & $\sqrt{ }$ & $\sqrt{ }$ & & & $\sqrt{ }$ & $\sqrt{ }$ & $\sqrt{ }$ & $\sqrt{ }$ & $\sqrt{ }$ & $\sqrt{ }$ & $\sqrt{ }$ \\
\hline Total & 18 & 7 & 6 & 3 & 3 & 1 & 15 & 21 & 10 & 15 & 12 & 1 & 19 \\
\hline
\end{tabular}

- Constituents with exceedances of 40 CFR Part 192 maximum concentration limits during at least two sampling rounds in ground water samples from wells on or downgradient of UMTRA Project processing sites, 1990 to 1995. Some of the constituents that exceed the maximum concentration limits may reflect naturally occurring conditions unrelated to uranium milling activities.

'The designated uranium mill sites at Belfield and Bowman, North Dakota, will not be remediated by DOE because the state of North Dakota has declined to provide its statutorily required cost-sharing to remediate the sites. The Lowman, Idaho, site has no ground water contamination.

'Data from most recent sampling rounds, 1987-1988.

NA - not applicable. 
support based on economic stimulus is not likely to be as strong for the Ground Water Project.

Funding for the UMTRA Ground Water Project is an element of the annual DOE ER budget request to Congress. Under the UMTRCA, states are required to fund cost sharing for remedial actions at the sites. The continued progress of the Project is therefore subject to appropriations from separate government agencies. Contingency plans may be advisable to address potential funding shortfalls to ensure Project progress is not jeopardized.

- Social factors - At many of the processing sites which had, or will have in the near term, the visible surface remedial action completed, the surrounding communities are anxious to commence with development of the sites and adjacent properties. However, if the underlying ground water is not acceptable for unrestricted use, the desire of the communities may be counter to the DOE requirement to ensure protection of human health and the environment. Development considerations will become an increasing consideration in the compliance strategy implementation and priority setting aspects of the Project.

- Cultural factors - The majority of the sites are located in arid environments with ground water resources relatively undeveloped and/or of critical cultural importance for continuation of traditional land uses in the West. Contaminated ground water has migrated beneath off-site properties at most of the sites, including tribal lands at five sites. Cultural factors may become an increasing consideration in the compliance strategy implementation and priority setting aspects of the Project.

- Environmental factors - A critical consideration is the environmental impacts associated with the continued off-site migration of contaminants which serves to increase the size of the plume.

- Regulatory factors - The successful progress and completion of the Project requires that DOE gain NRC and stakeholder approval of the PEIS, sitespecific EAs, and selected compliance strategies. It is appropriate that cooperative agreements be negotiated and approved in a timely fashion, that the primacy of guiding regulations (federal, state, local) be consistently assessed should ACLs or supplemental standards (per 40 CFR Part 192, Subpart B) be considered at some sites, and that there is assurance that any compliance strategy which includes institutional controls be capable of implementation by the cognizant state, tribal, or local governing agency for the period of time required.

- Other factors - Institutional controls such as deed restrictions to control limit or prohibit use of contaminated ground water may be an important component of the final compliance strategy at several of the sites. 
Implementation and enforcement of institutional controls, statutory or codified restrictions on private land and resource uses, will be difficult to obtain. The states, tribes, and/or local governments would be important players in implementing and enforcing this potential compliance strategy at the sites. However, the legality and enforceability of institutional controls may have to be determined on a case-by-case basis.

\subsection{FUTURE USES OF LAND, FACILITIES, AND EQUIPMENT}

The use of surrounding lands is also a concern from the perspective that plumes at most sites have already migrated off-site. The impact to the Project of having contamination impacting private property or tribal lands is far greater than having the plumes migrate onto publicly held lands. The Project cleanup criteria are prescriptive and are largely independent of land use. The current and potential future uses of the land will have to be evaluated when assessing the prioritization of the site activities as well as the implementation of institutional controls. At sites where the surface disposal cell is on the site (SIP or SOS sites), future land use will be limited somewhat by the presence of the disposal cell. Sites where the tailings and other RRM were removed may be returned to the state, tribe, or private landowner. In some cases this has already happened prior to the completion of the ground water activities at the site. The sites located on tribal lands will remain the property of the tribe.

The Project does not anticipate leaving any substantial quantity of equipment or facilities in place at the end of the Project which are government owned or operated. Alternative water supply systems or other facilities would be left in place but ownership will be transferred from DOE to another entity before the Project is completed. 


\section{Figure 2.2-1}

\section{Sulfate Concentrations in Ground Water Ambrosia Lake, New Mexico, Site}

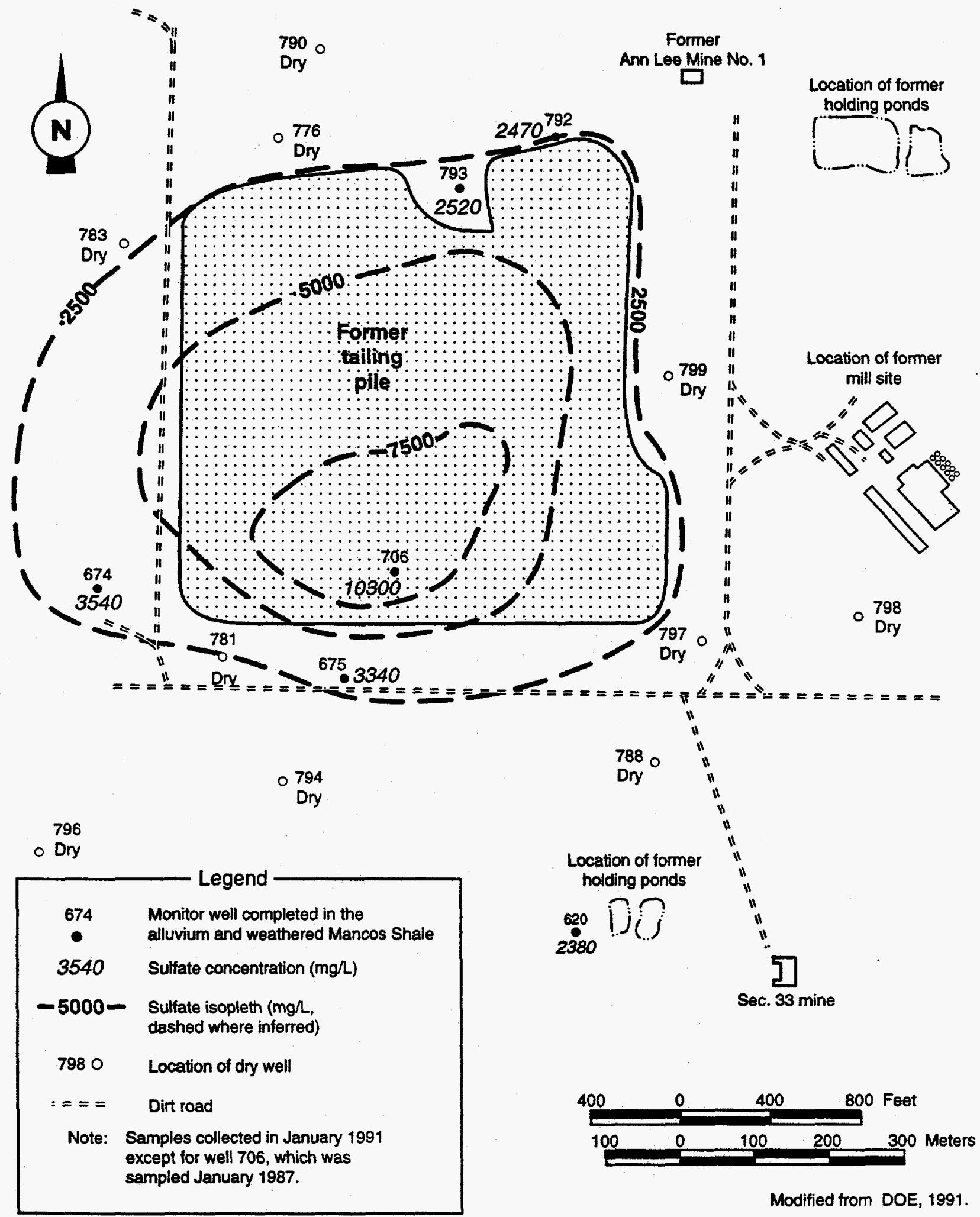




\section{Figure 2.2-2 \\ Uranium Concentrations in Ground Water Canonsburg, Pennsylvania, Site}

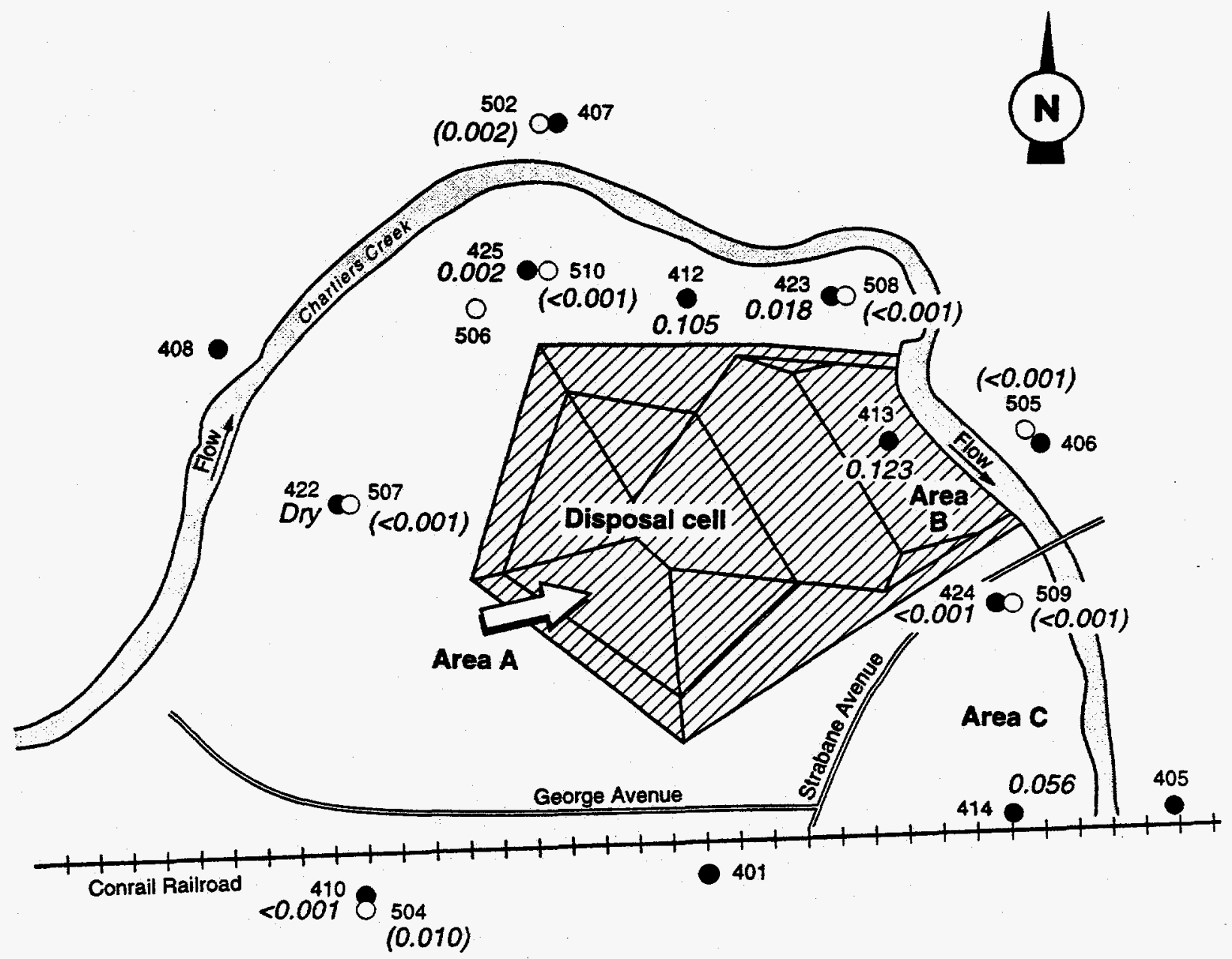

$409 \bigcirc 503$

Legend

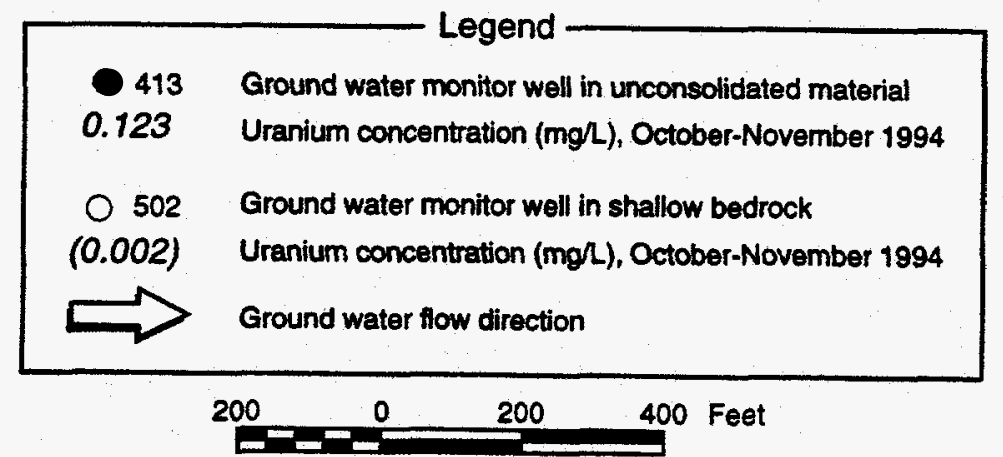

MAC: NONSITE/GWMAPSICANUAAN.AI 


\section{Figure 2.2-3}

\section{Chloride Concentrations in Ground Water}

\section{Durango, Colorado, Site}

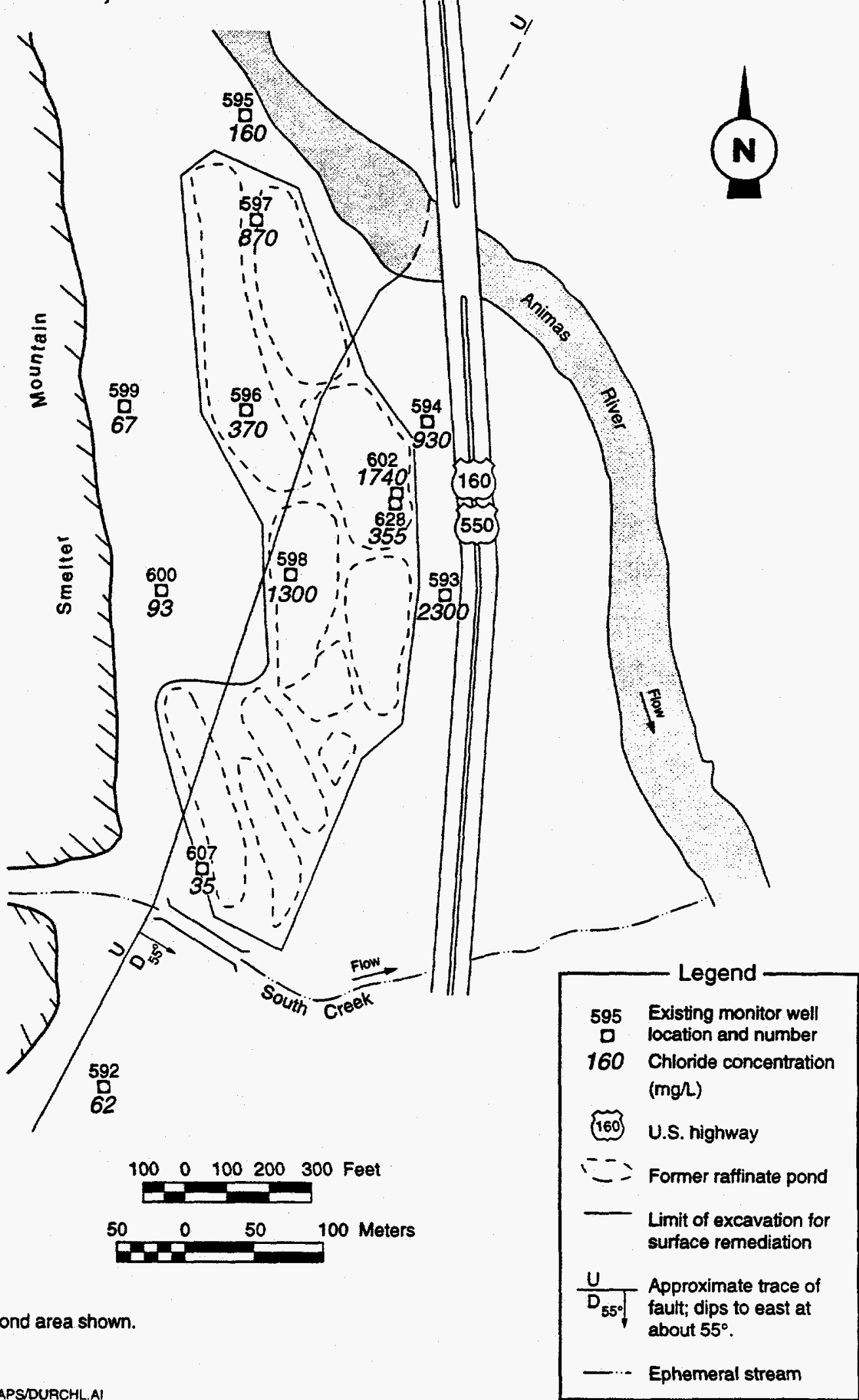

MAC: NONSTTE/GMMAPSTURCHL AI 


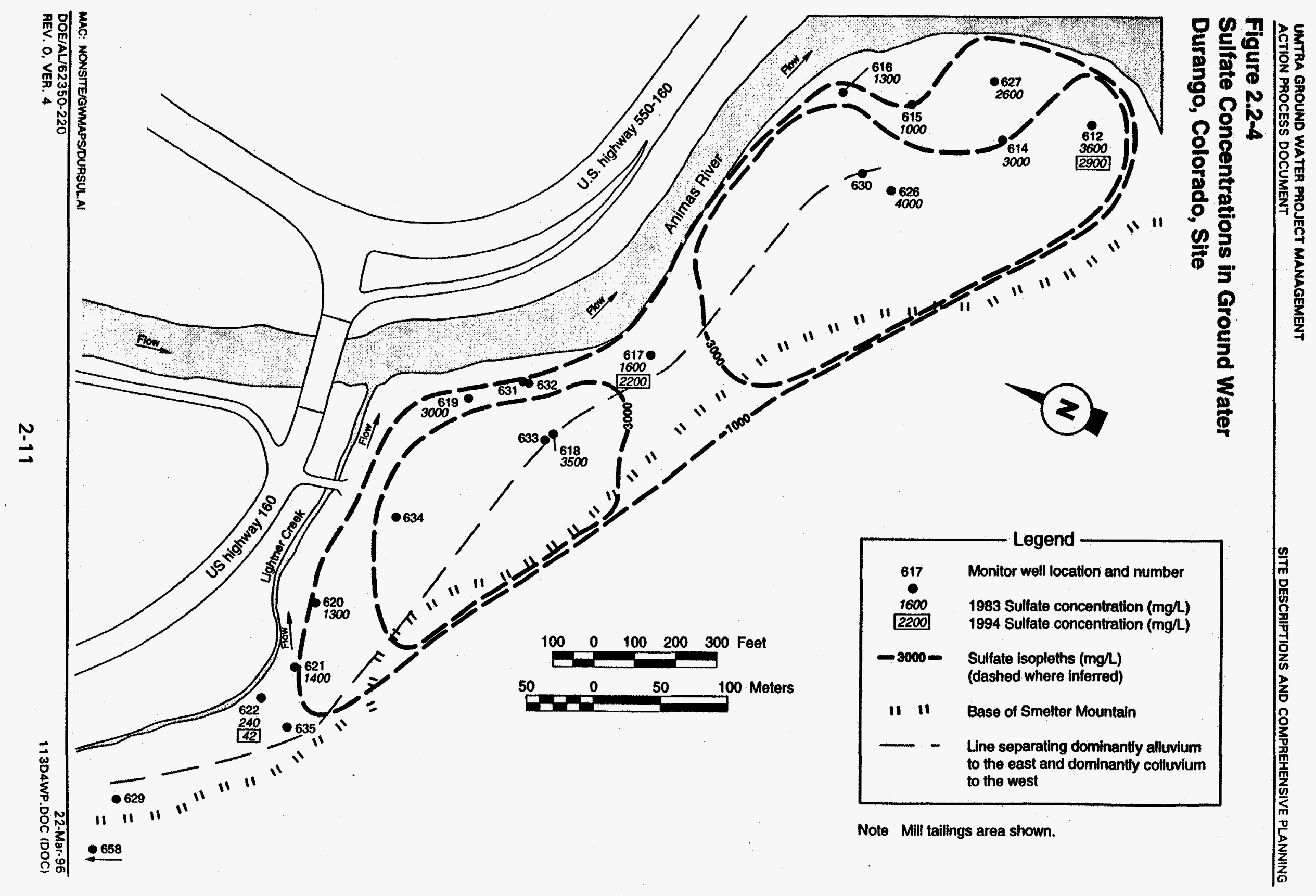




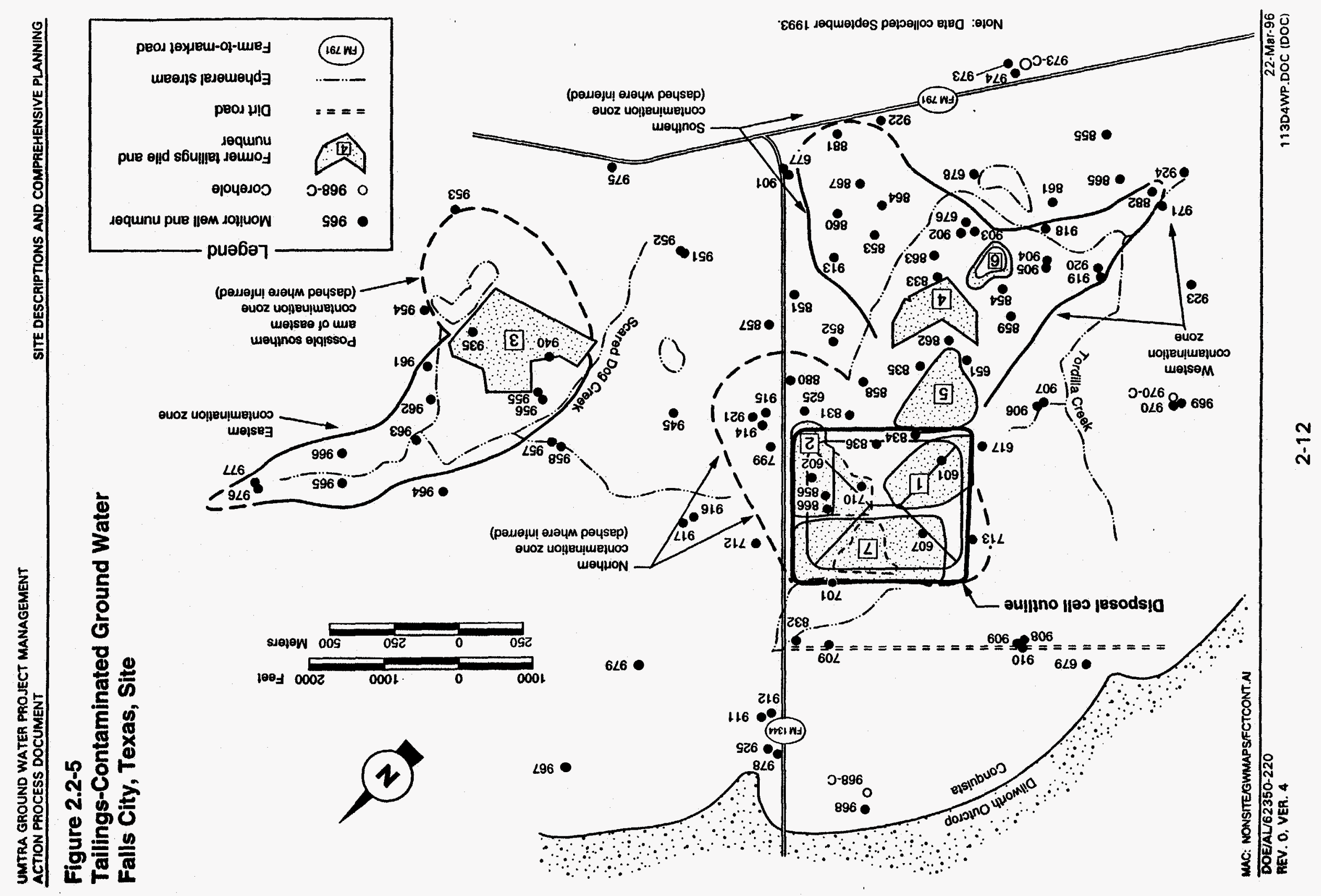




\section{Figure 2.2-6}

\section{Uranium Concentrations in Ground Water Grand Junction, Colorado, Site}
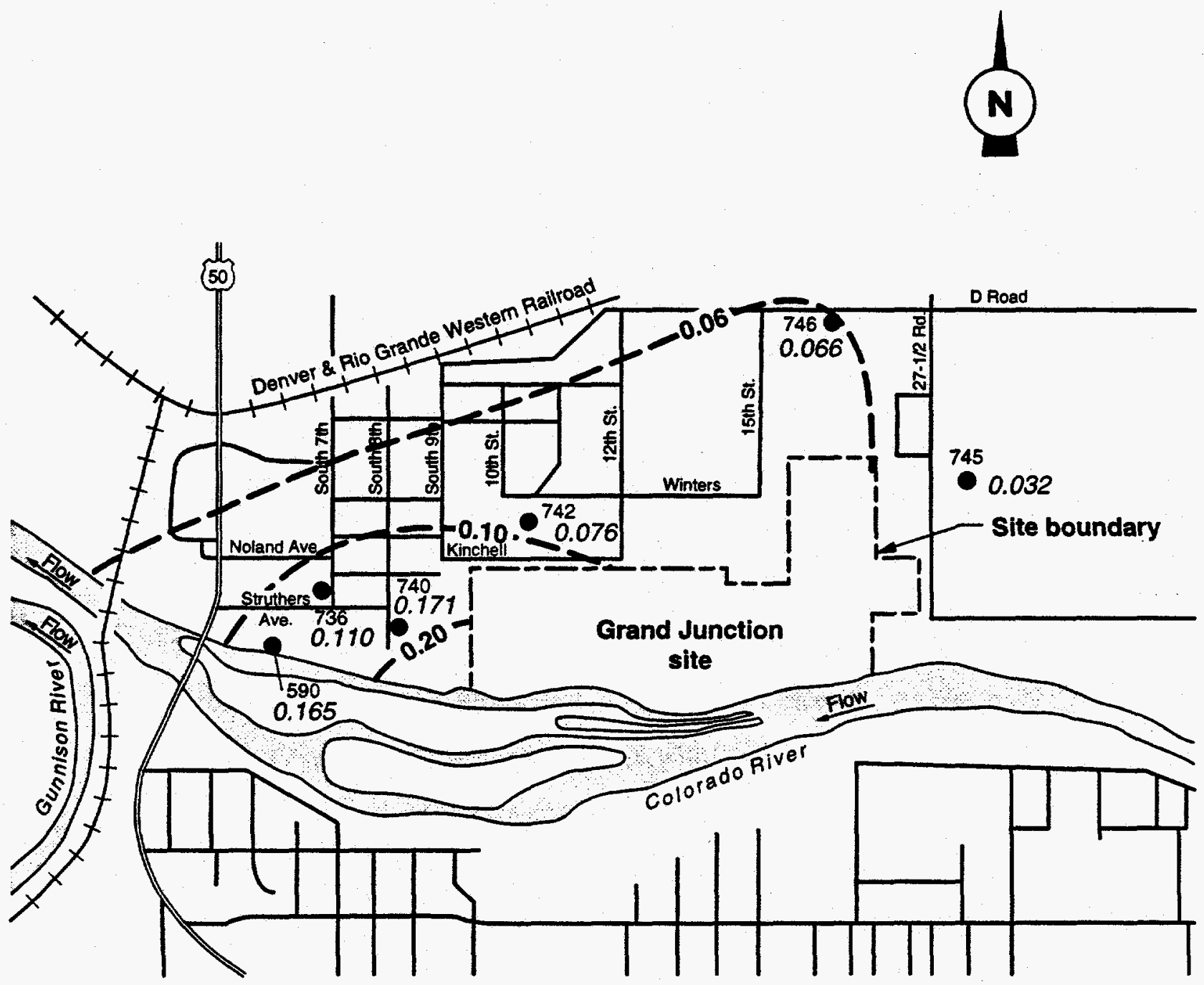

Note: Data collected June 1994.

\section{Legend}

$$
\begin{array}{cl}
-0.06- & \begin{array}{l}
\text { Uranium concentration } \\
\text { contour (mg/, dashed } \\
\text { where inferred) }
\end{array} \\
0.746 & \text { Ground water monitor well } \\
0.066 & \text { Uranium concentration (mgh) } \\
50 & \text { U.S. highway }
\end{array}
$$

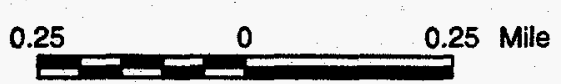


Figure 2.2-7

Uranium Concentrations in Ground Water

Green River, Utah, Site

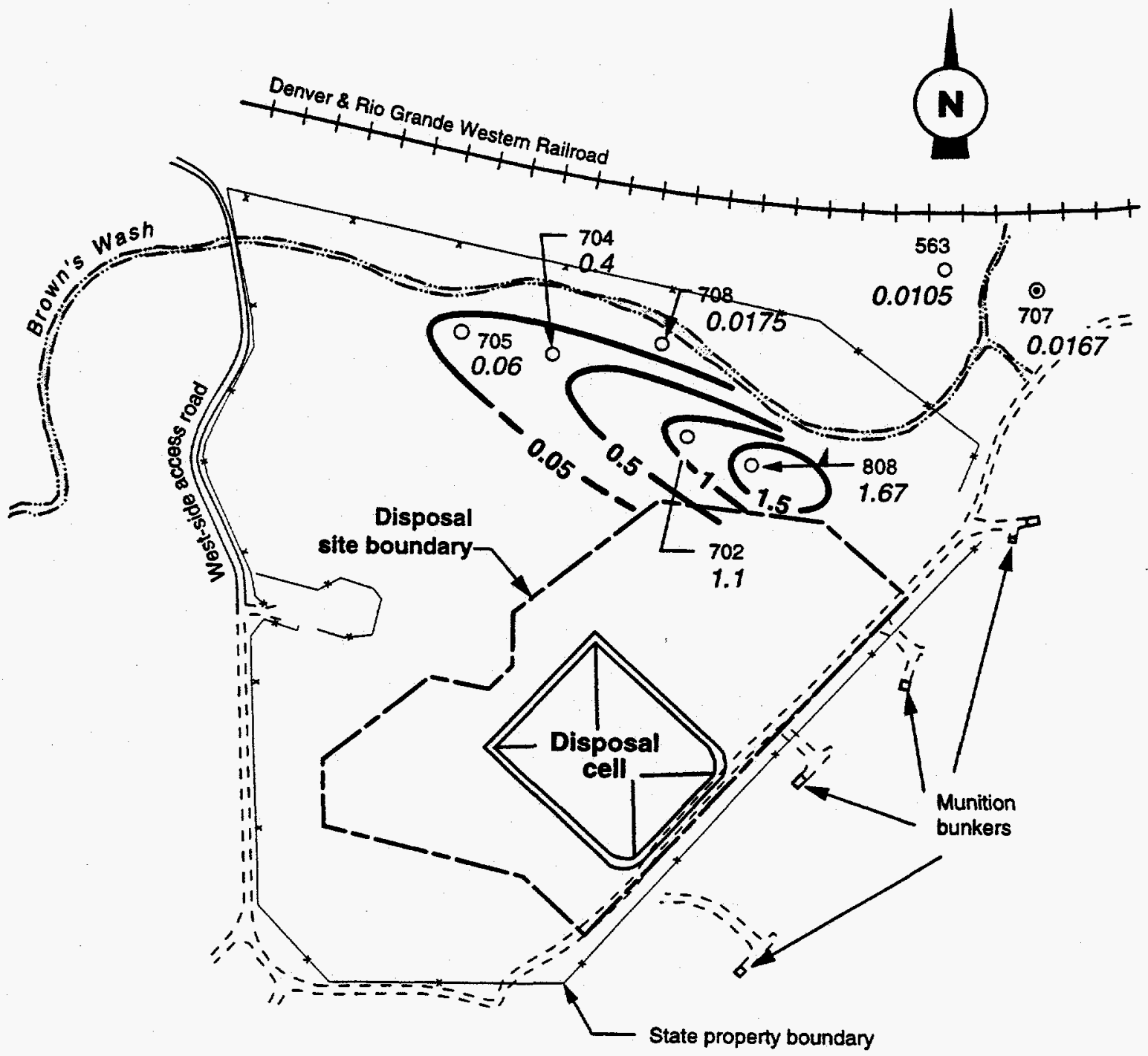

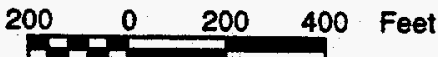

$50 \quad 0 \quad 50 \quad 100$ Meters
Legend

0707 Existing site monitor well

0.0167 Uranium concentration (mg/L)

0705 Decommissioned monitor well

0.06 Uranium concentration ( $\mathrm{mg} / \mathrm{L}$ )

$0.5-$ Uranium isopleth ( $\mathrm{mg} / \mathrm{L}$ )

$=== \pm \quad$ Dirt road

-... Ephemeral stream 


\section{Figure 2.2-8}

\section{Sulfate Concentrations in Ground Water}

\section{Gunnison, Colorado, Site}

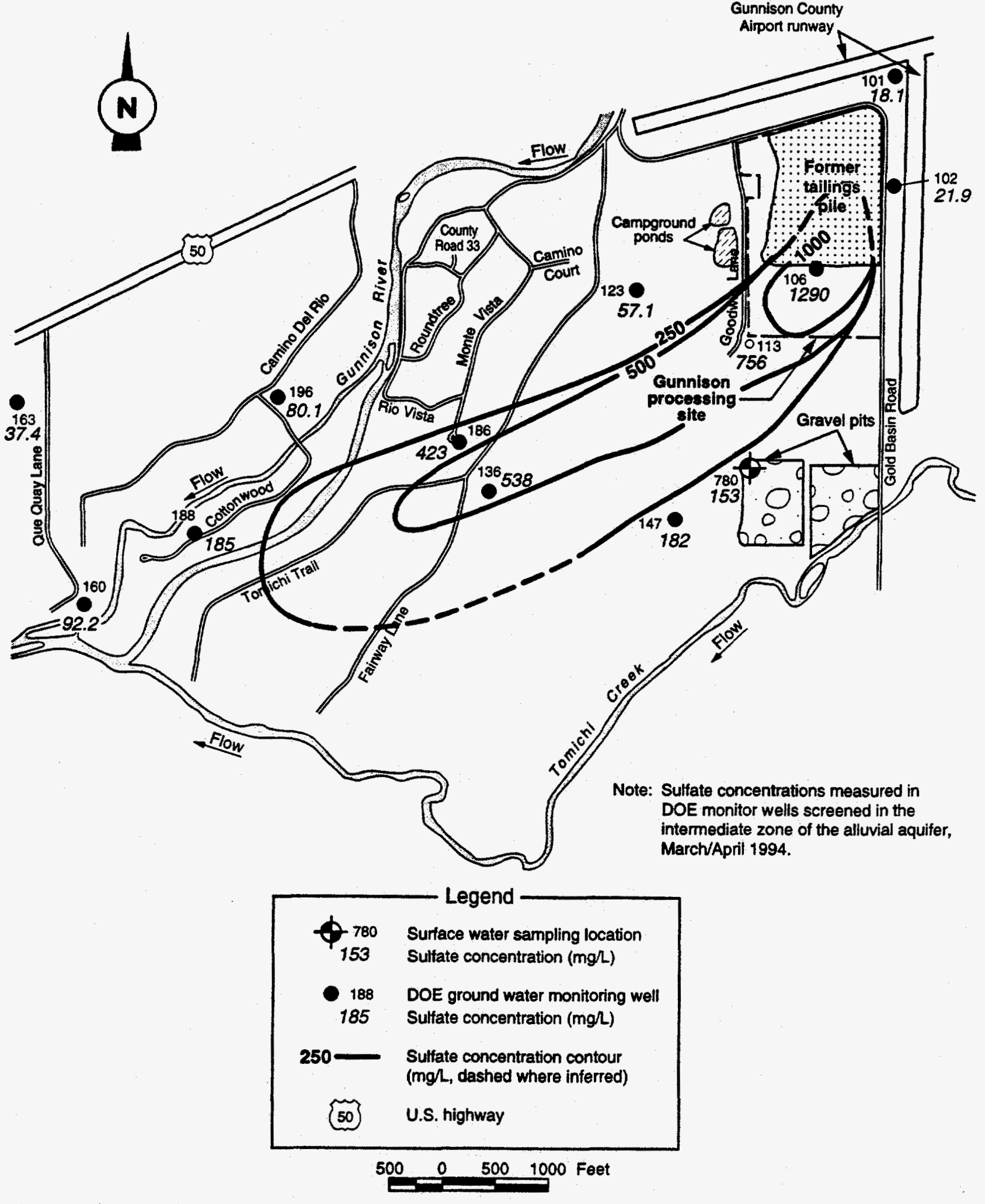

MAC: NONSITENGWMAPSHGUNSUL.AI 


\section{Figure 2.2-9}

\section{Sulfate Concentrations in Ground Water}

\section{Lakeview, Oregon, Site}
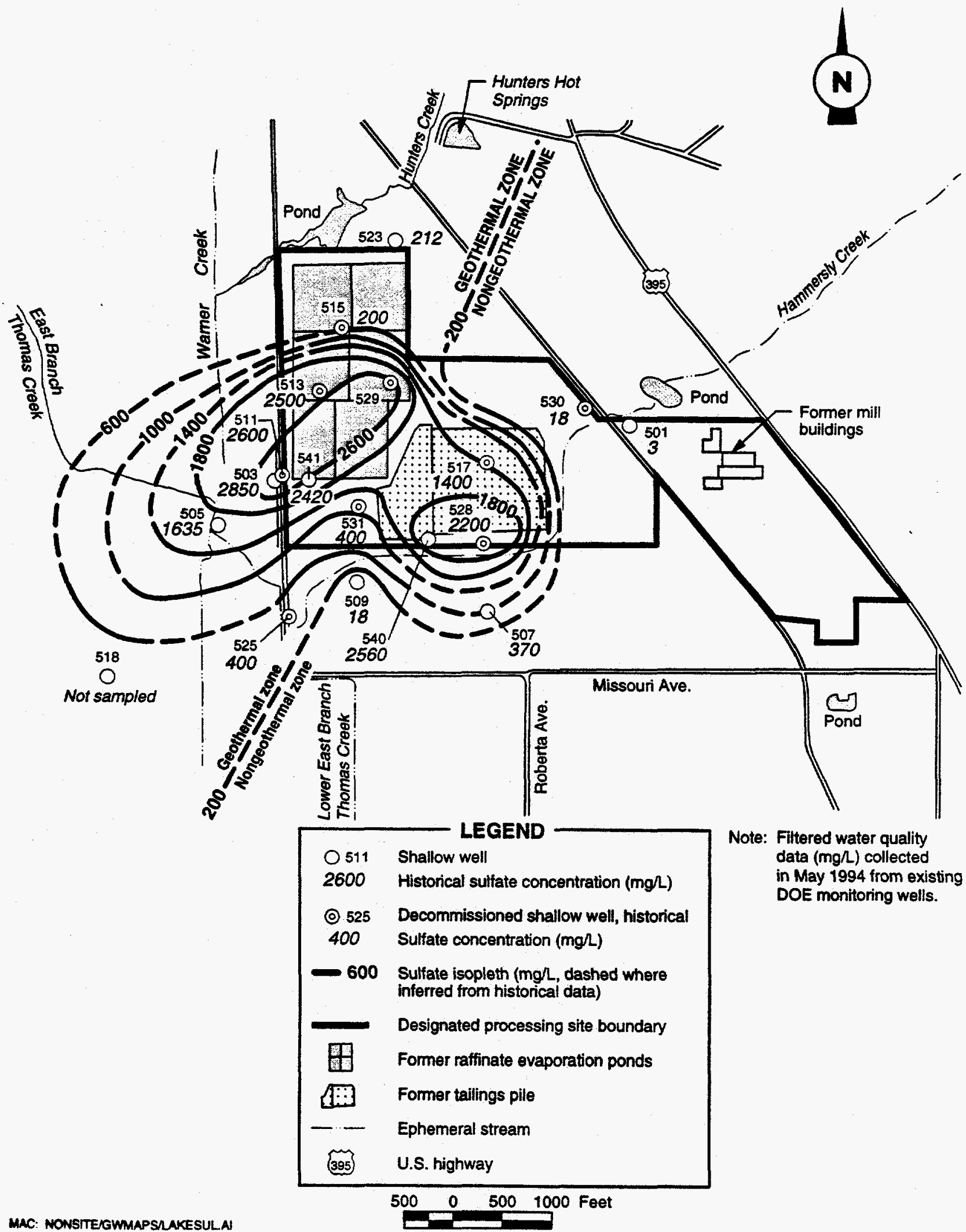

Note: Filtered water quality data (mg/) collected in May 1994 from existing DOE monitoring wells. 


\section{Figure 2.2-10}

Nitrate and Uranium Concentrations in Ground Water

Maybell, Colorado, Site

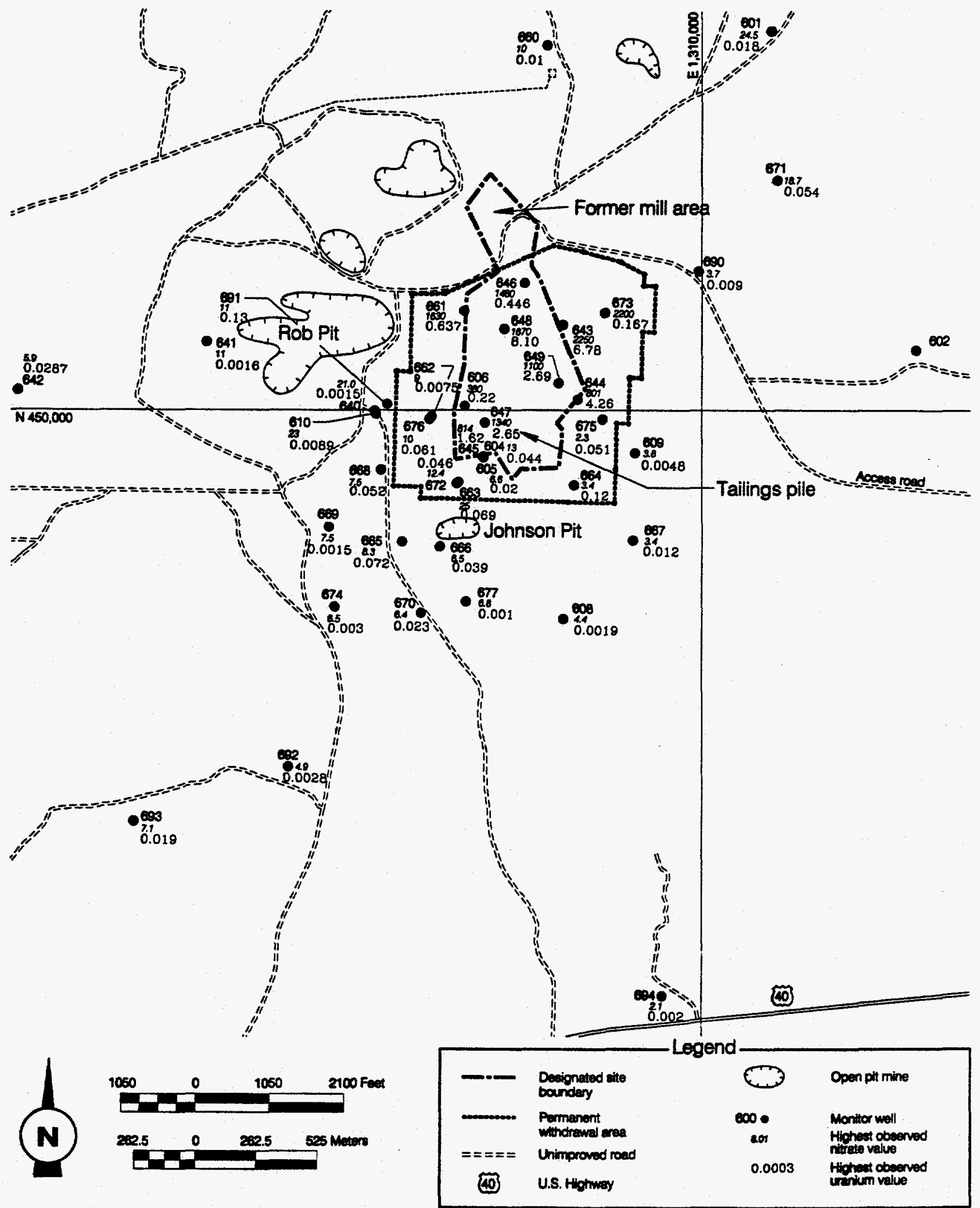

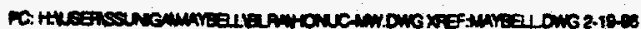


Figure 2.2-11

\section{Tailings-Contaminated Ground Water}

\section{Mexican Hat, Colorado, Site}

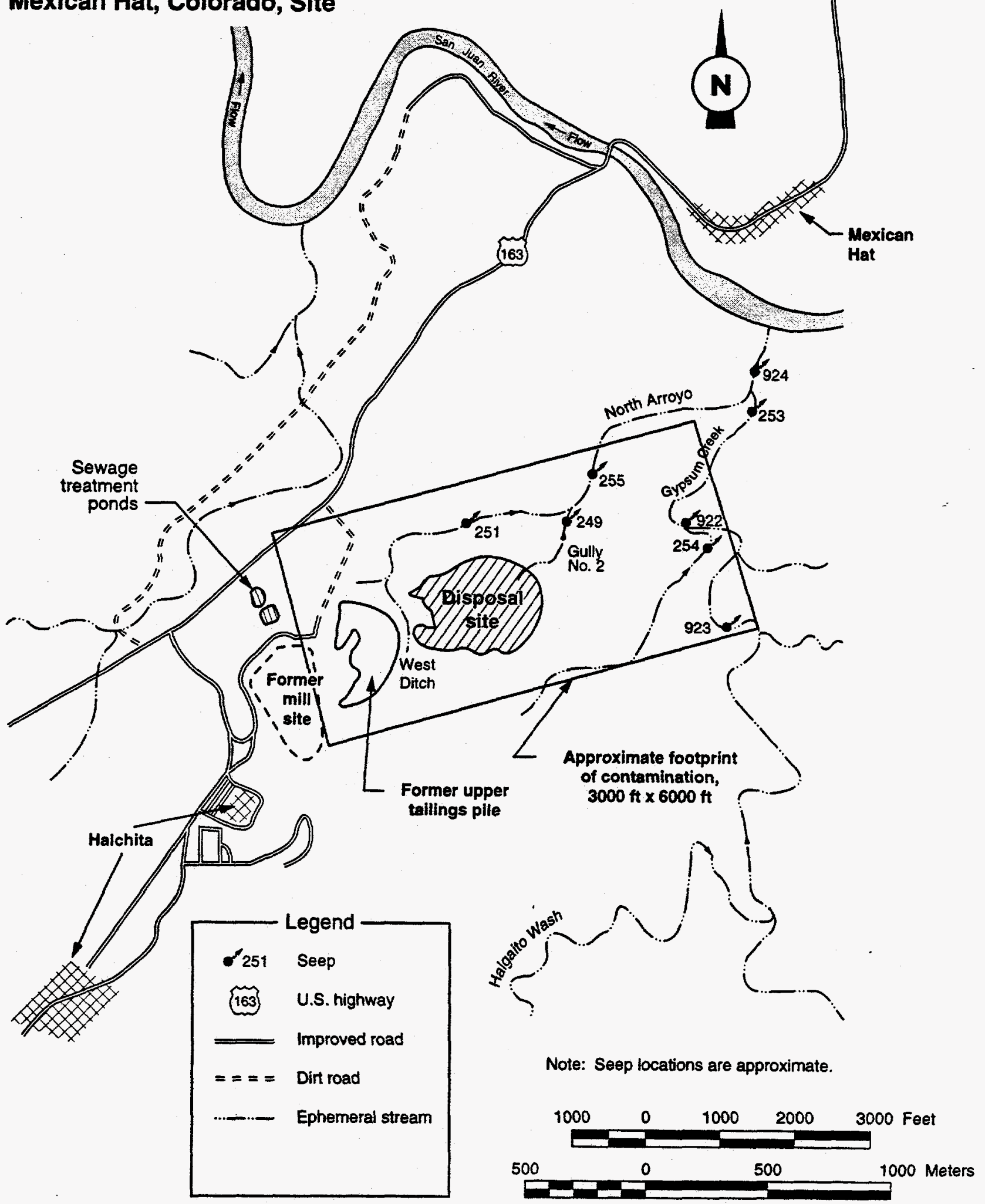


Figure 2.2-12

Nitrate Concentrations in Ground Water

Monument Valley, Arizona, Site

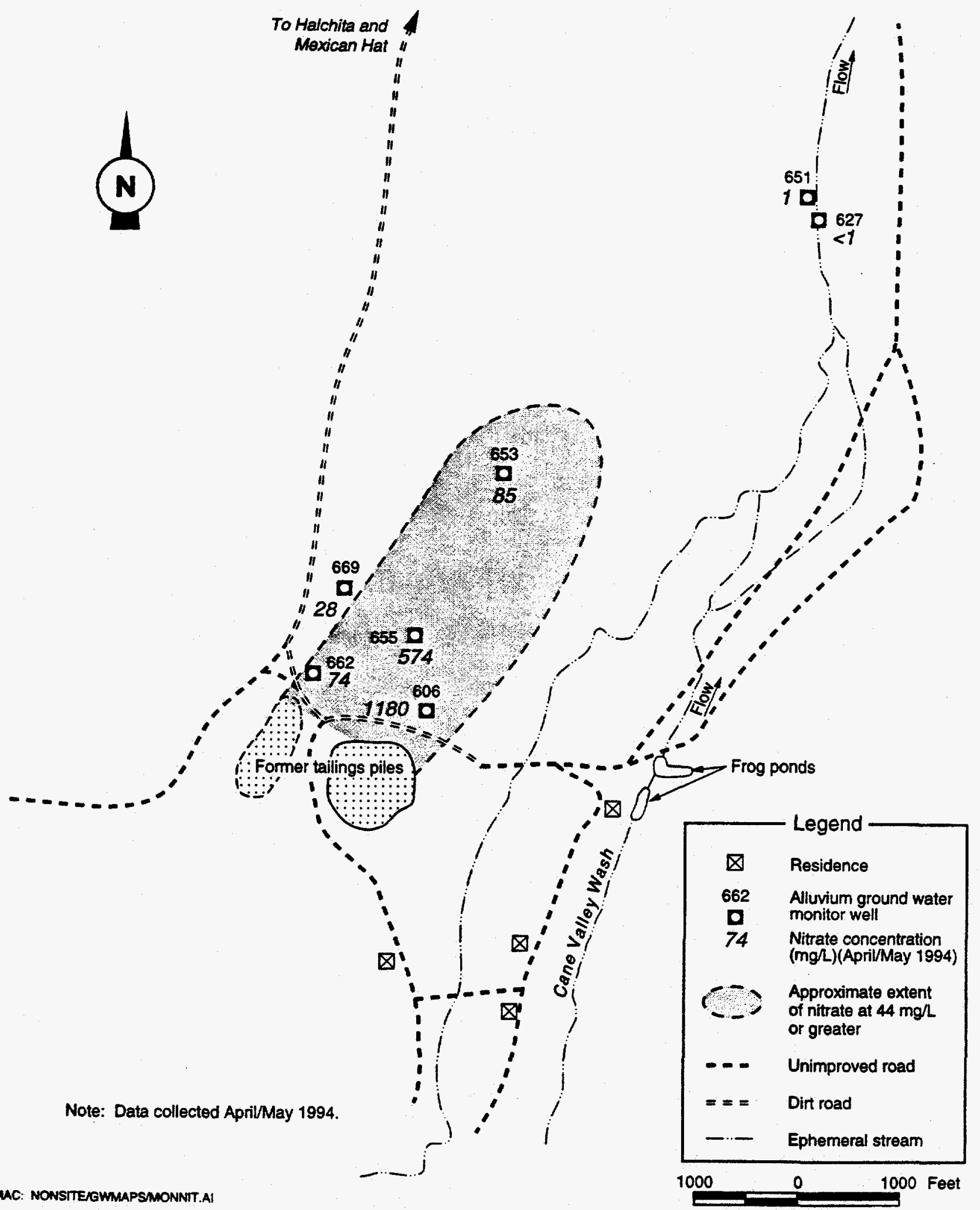




\section{Figure 2.2-13}

\section{Uranium Concentrations in Ground Water}

Naturita, Colorado, Site

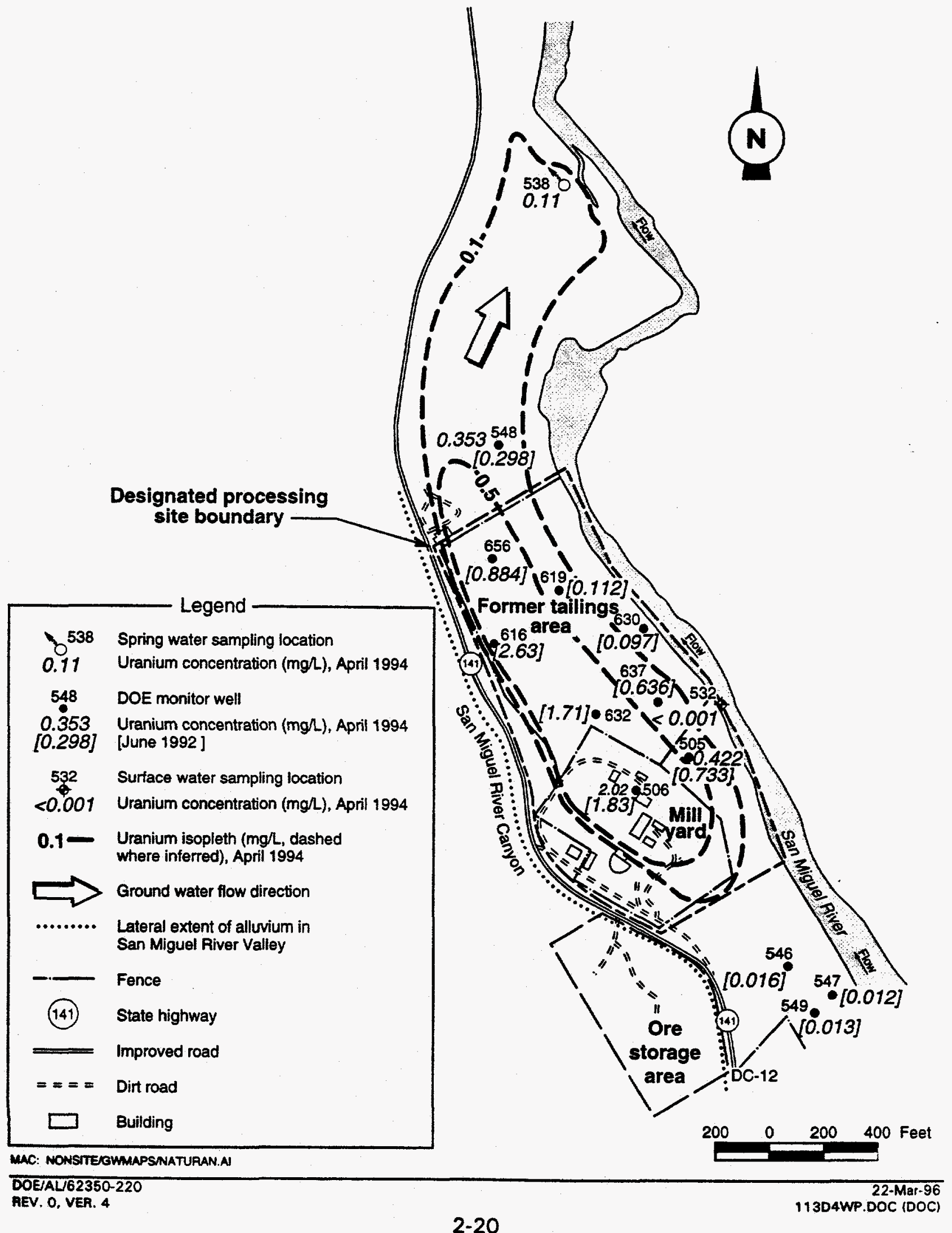




\section{Figure 2.2-14}

\section{Sulfate Concentrations in Ground Water}

New Rifle, Colorado, Site

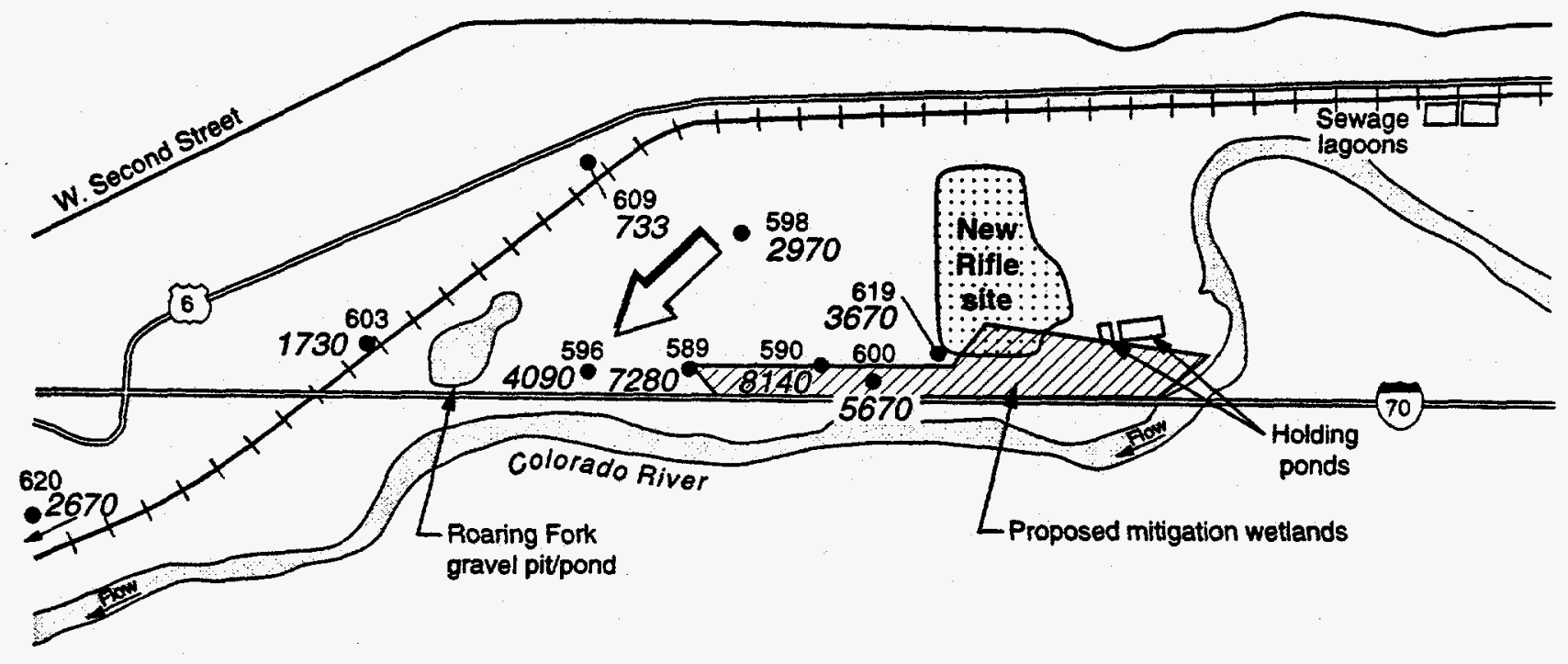




\section{Figure 2.2-15}

Sulfate Concentrations in Ground Water

Old Rifle, Colorado, Site

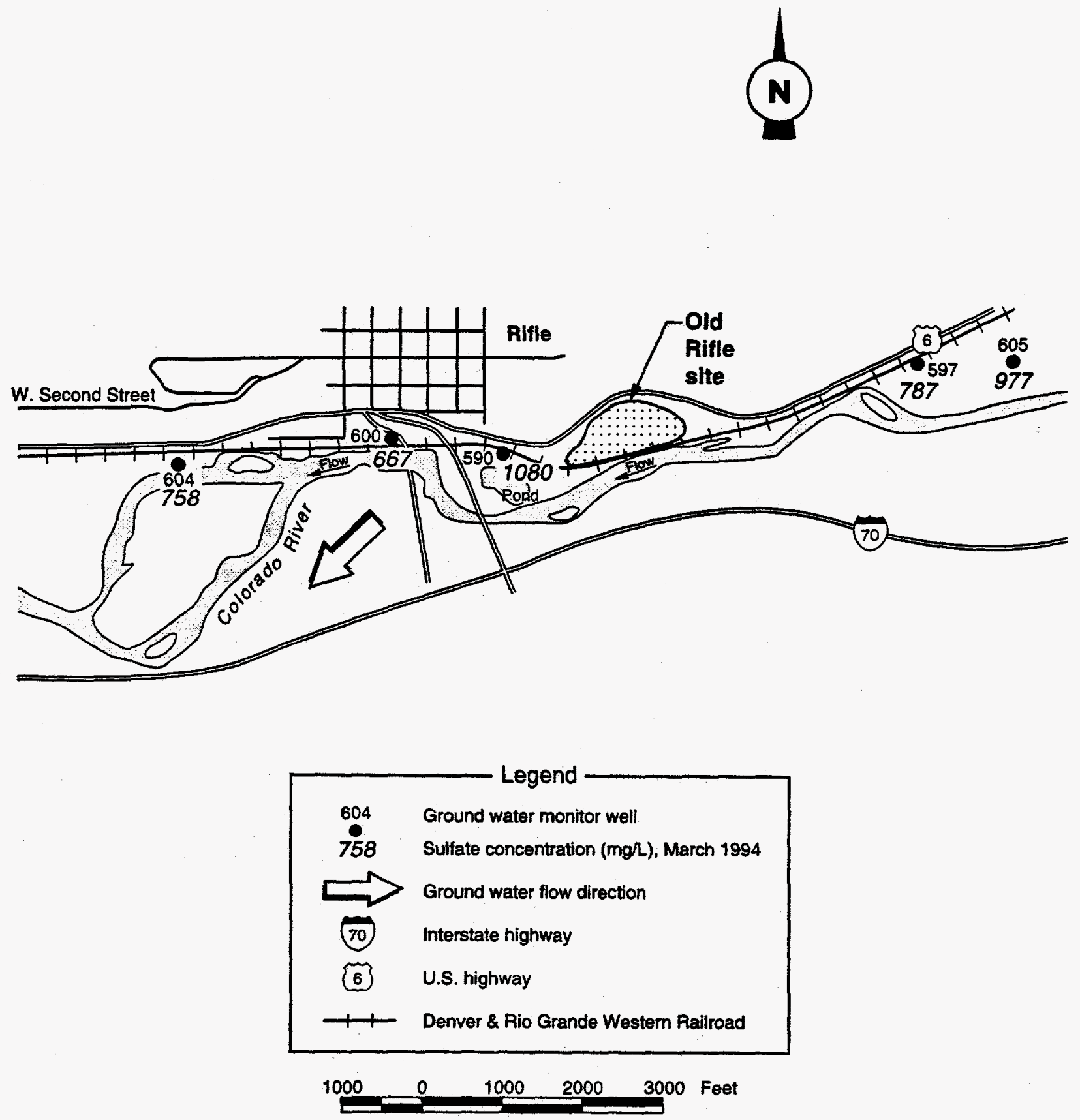

MAC: NONSITEKGMMAPSIOLDRFLAI 
Figure 2.2-16

\section{Uranium Concentrations in Ground Water}

Riverton, Wyoming, Site

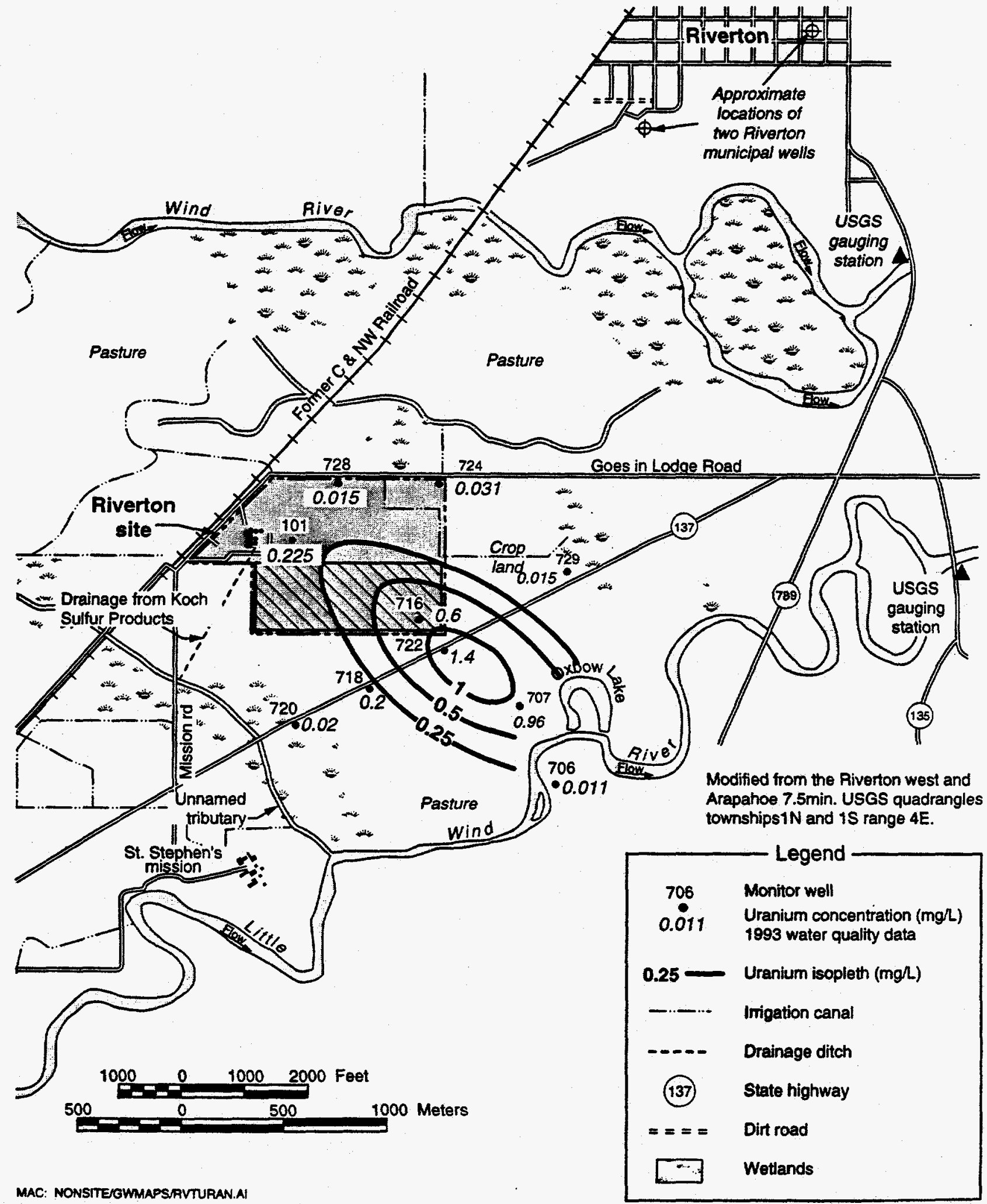




\section{Figure 2.2-17}

\section{Sulfate Concentrations in Ground Water}

\section{Salt Lake City, Utah, Site}
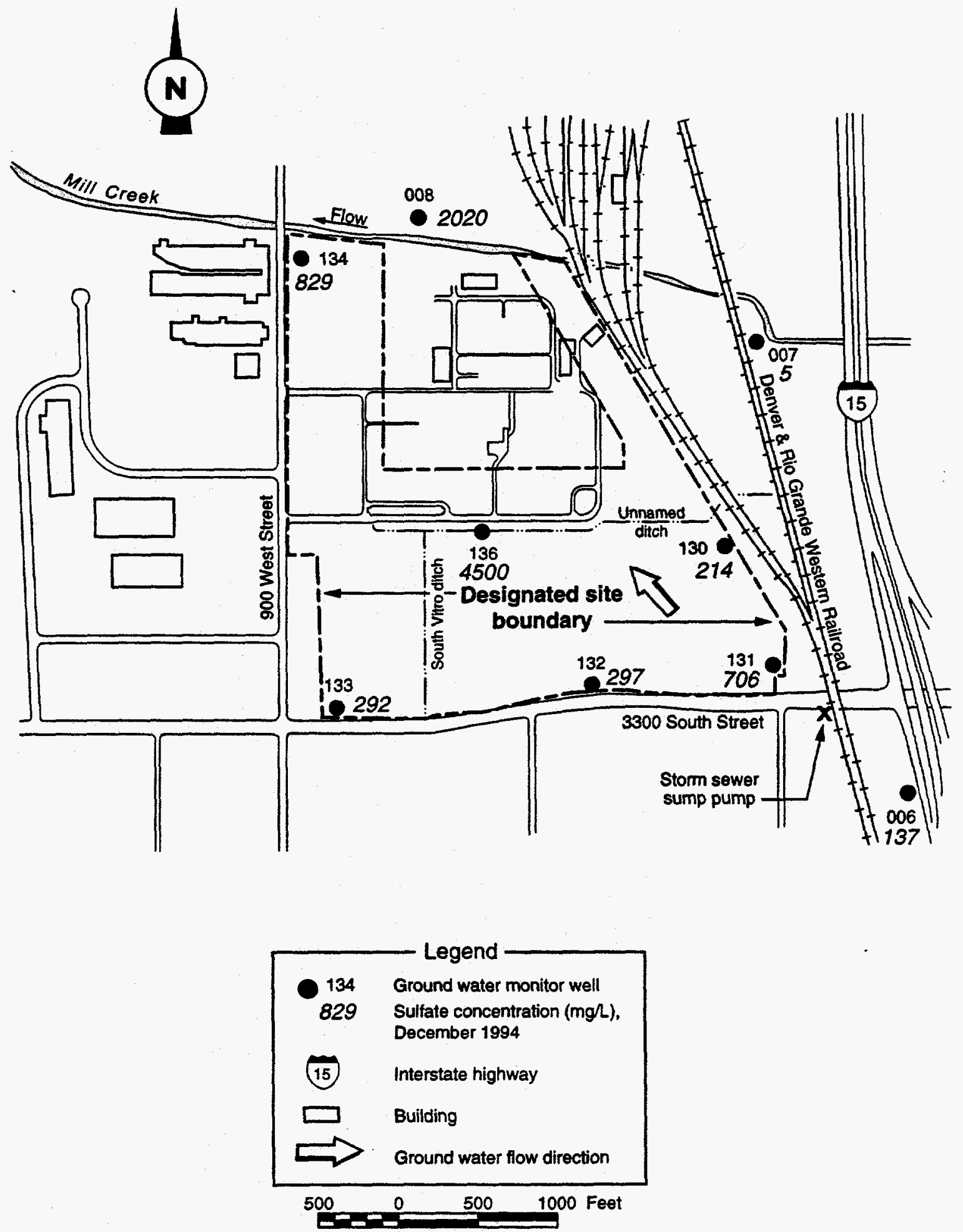

MAC: NONSTTEGWMAPSISLCSUL.A 


\section{Figure 2.2-18}

\section{Uranium Concentrations in Ground Water Shiprock, New Mexico, Site}

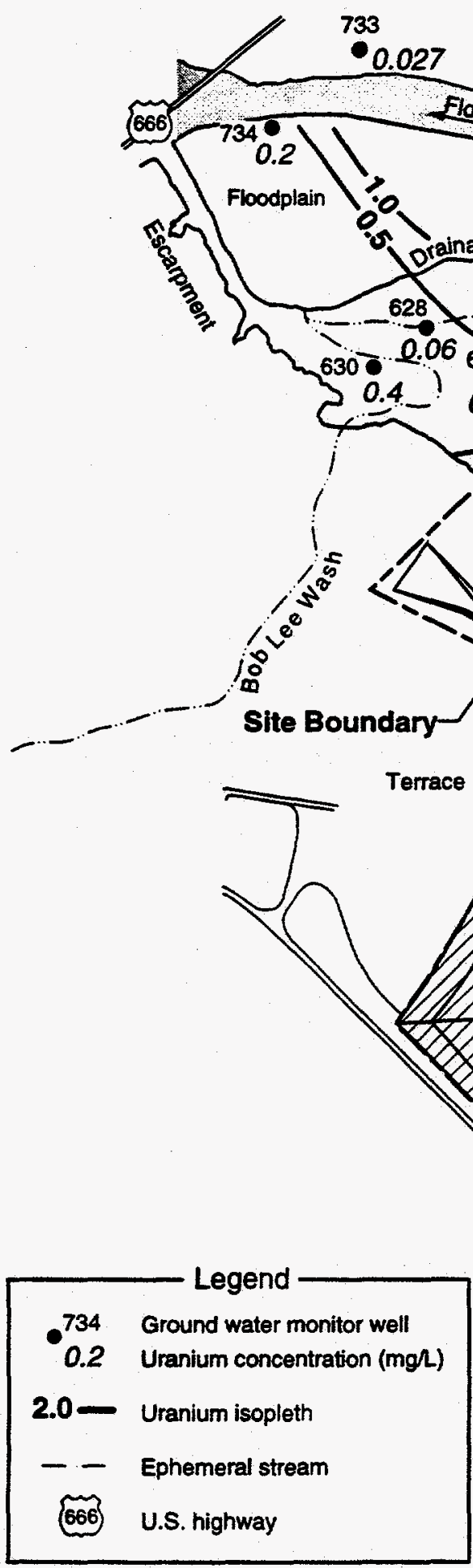

MAC: NONSITEGGMAPSISHPURAN.AI
Note: Water quality data from September 1992 except monitor wells 734, 735, 736 (April 1993), 612 (April 1989). 


\section{Figure 2.2-19}

\section{Uranium Concentrations in Ground Water}

North Continent and Union Carbide Sites, Slick Rock, Colorado

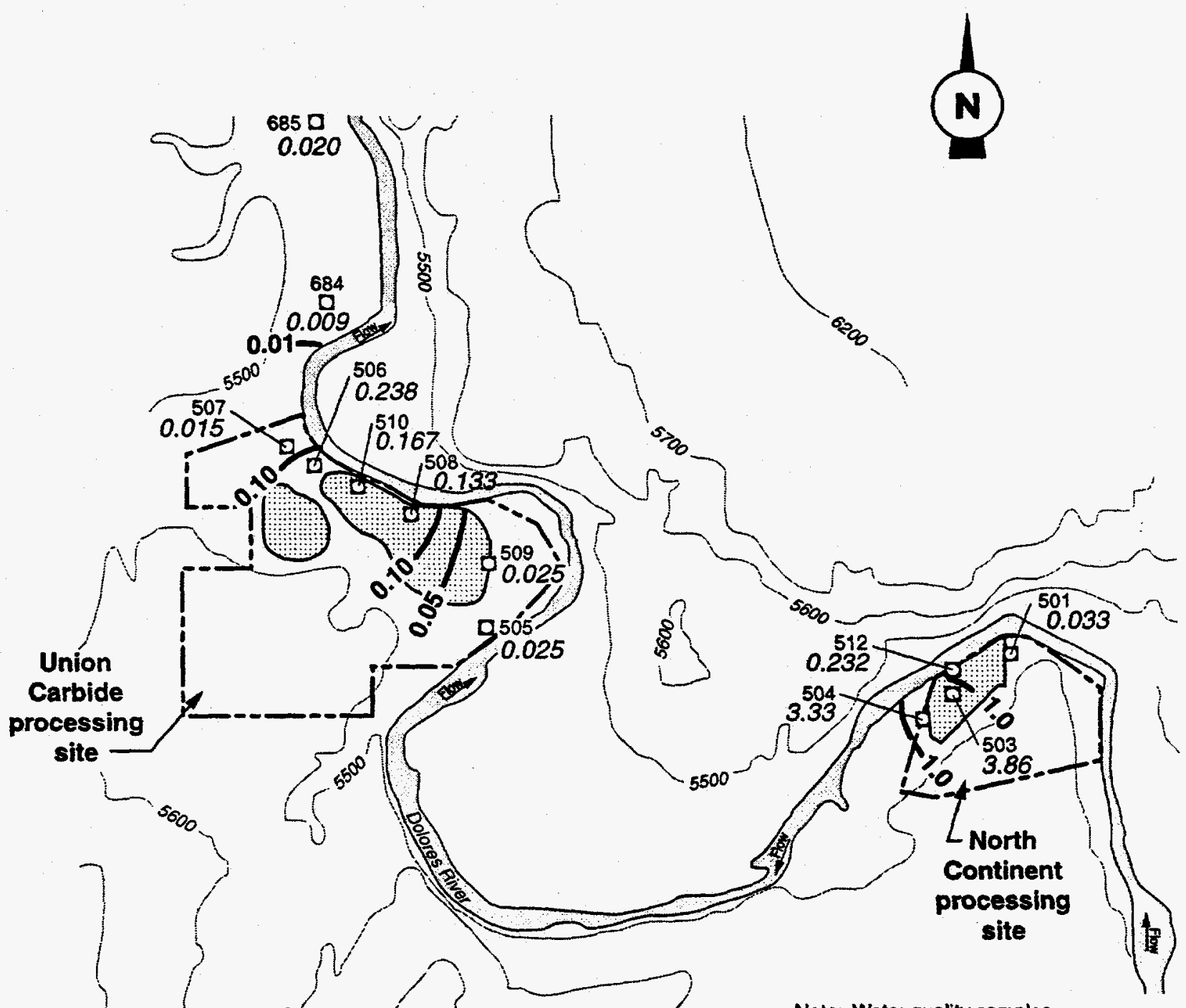

Note: Water quality samples

Legend

collected in February 1994

MAC: NONSTTEKGMMAPSISAKURAN.A 

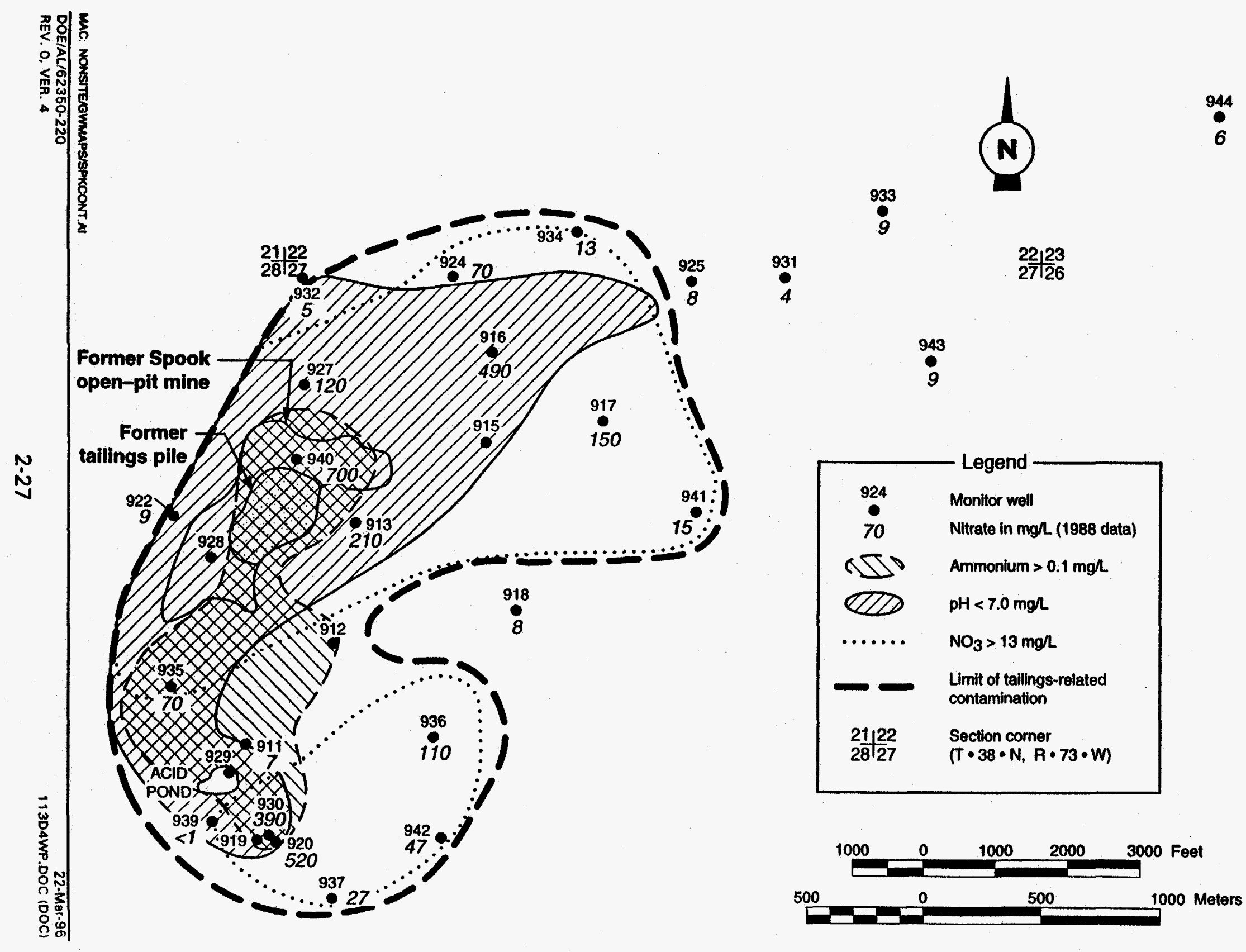

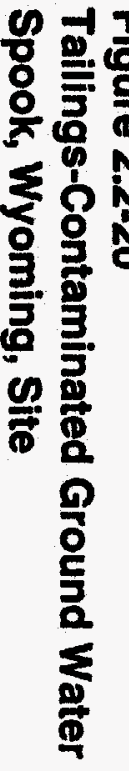

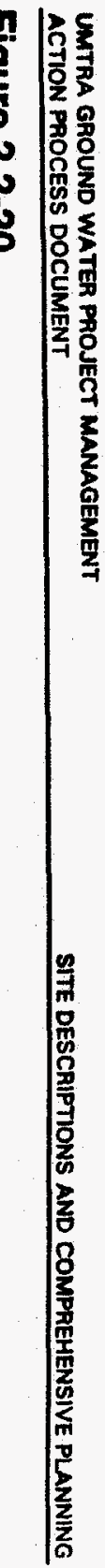




\section{Figure 2.2-21}

Nitrate Concentrations in Ground Water

Tuba City, Arizona, Site

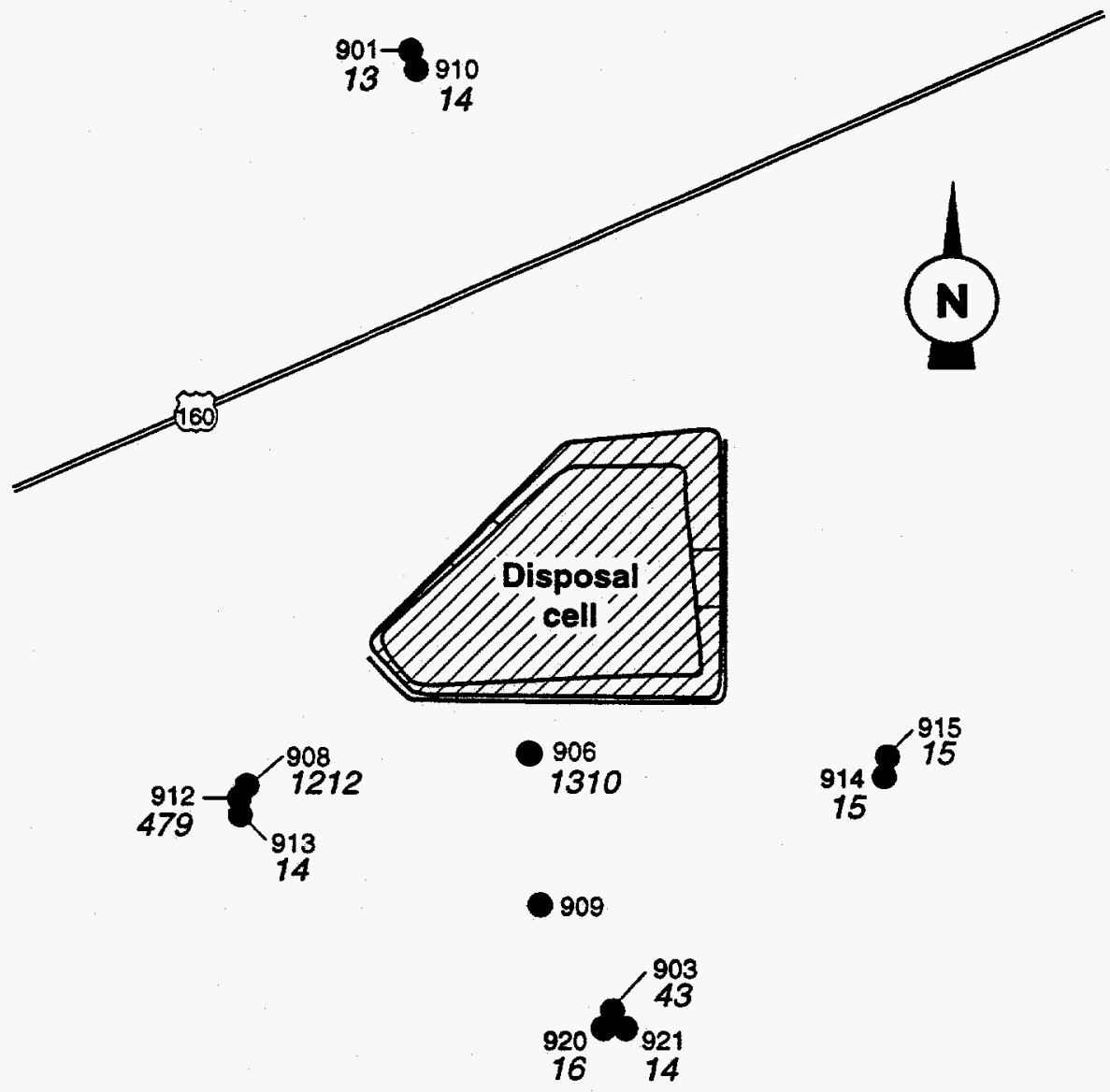

917

17

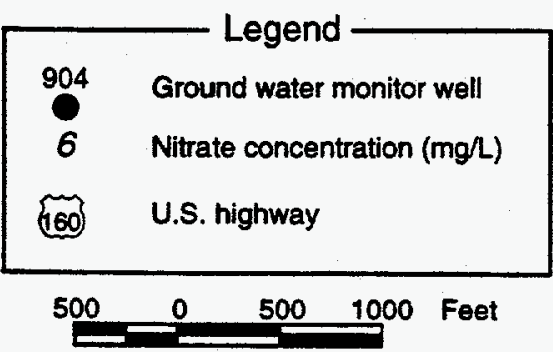

904

6

MAC: MONSTTERWMAPS/TUBNIT.AI

Note: Data collected August 1994. 


\subsection{STATUS OF ENVIRONMENTAL RESTORATION ACTIVITIES}

This section summarizes the programmatic status of the Project. The major programmatic activities for the coming year are the completion of the PEIS and ROD, programmatic implementation of actions toward the ITR recommendations, transition of both the project management and contractual support from DOE-AL to DOE-GJPO, evaluation of the requirement for any interim actions at the sites, and development of a model cooperative agreement with the affected states and tribes.

\subsection{CURRENT ENVIRONMENTAL RESTORATION ACTIVITIES}

All sites are either in the characterization or planning phase. The eventual compliance strategy for all sites has yet to be determined. However, sitespecific strategies have been assumed as a basis for cost estimates for budget development purposes only (Table 3.1-1). The Belfield and Bowman sites are not presently scheduled for further Project activities because the state has declined participation in the UMTRCA-mandated cost-sharing. The Lowman site is not scheduled for further Project activities because the NRC concurred with the Surface Project RAP, which recommended no further ground water action due to the lack of ground water contamination. The compliance strategy approaches are:

- No Remediation - No ground water remediation could be used under two circumstances: first, at sites that do not have ground water contamination above maximum concentration limits and/or background levels, and second, at sites that have ground water contamination above maximum concentration limits and/or background levels but qualify for supplemental standards or ACLs. Use of this strategy could involve a demonstration of compliance and, in some cases, additional site characterization.

- Natural Flushing - Natural flushing is passive ground water remediation because it does not involve manipulation of ground water flow, quantity, or quality. Natural flushing could be used at sites where compliance with the ground water standards would occur within a period of 100 years or less; where adequate monitoring and institutional controls could be established and maintained throughout the flushing period; where institutional controls could result in conditions that were protective of human health and the environment; and where the ground water was not a current nor a projected drinking water source.

- Active Remediation - Active ground water remediation would be used at sites where methods such as gradient manipulation, ground water extraction, and in situ ground water treatment were required in order to meet the ground water standards. 
Table 3.1-1 Targeted site compliance strategies

\begin{tabular}{lcc}
\hline \multicolumn{1}{c}{ Site } & Proposed strategy & Applicable standard \\
\hline Ambrosia Lake & No remediation & SS \\
Belfield & Not applicable & Not applicable \\
Bowman" & Not applicable & Not applicable \\
Canonsburg & No remediation & ACL \\
Durango & Passive remediation-natural flushing & MCL/BG \\
Falls City & No remediation & SS \\
Grand Junction & Passive remediation-natural flushing & SS \\
Green River & No remediation & SS \\
Gunnison & Passive remediation-natural flushing & MCL/BG \\
Lakeview & No remediation & SS \\
Lowman & No remediation & MCL/BG \\
Maybell & No remediation & SS \\
Mexican Hat & No remediation & SS \\
Monument Valley & Active remediation & MCL/BG \\
Naturita & Passive remediation-natural flushing & MCL/BG \\
New Rifle & Passive remediation-natural flushing & MCL/BG \\
Old Rifle & Passive remediation-natural flushing & MCL/BG \\
Riverton & Passive remediation-natural flushing & MCL/BG \\
Salt Lake City & No remediation & SS \\
Shiprock & No remediation & SS \\
Slick Rock - NC & Passive remediation-natural flushing & MCL/BG \\
Slick Rock - UC & Passive remediation-natural flushing & MCL/BG \\
Spook & No remediation & SS \\
Tuba City & Active remediation & MCL/BG \\
\hline
\end{tabular}

The designated uranium mill sites at Belfield and Bowman, North Dakota, will not be remediated by DOE because the state of North Dakota has declined to provide its statutorily required cost-sharing to remediate the sites.

MCL/BG - maximum concentration limits and/or background levels.

SS - supplemental standards.

$A C L$ - alternate concentration limits.

NC - North Continent.

UC - Union Carbide. 
Table 3.1-2 summarizes the potential negative impacts of each of the ground water compliance strategies. The table shows that the number of negative impacts is highest for active remediation, next highest for natural flushing, and lowest for no remediation sites that meet the standards with supplemental standards or ACLS.

Figures 2.1-1 through -21 show the ground water plumes at UMTRA sites based on the concentrations of indicator parameters.

\subsection{REgULATORY AGREEMENTS, CONSENT DECREES, COMPLIANCE, AND} OTHER LEGAL DRIVERS

The legal driver for the Project is the UMTRCA. Under the terms of the UMTRCA, the EPA has established the ground water protection standards in 40 CFR Part 192. The NRC is responsible for evaluating and certifying the Project's compliance with the EPA standards. A model cooperative agreement is under development for use in later negotiations with the affected states and tribes and scheduled to be completed by mid-FY1997. Table 3.2-1 lists the cooperative agreements scheduled for implementation.

\subsection{CURRENT WASTE MANAGEMENT AND MATERIAL DISPOSITION ACTIVITIES}

The Project is currently only producing investigation-derived wastes (drill cuttings and purge waters) and is disposing of them on site based upon field screening. If a site requires an active method of remediation such as pump and treat, or if purge water is determined to be unacceptable for on-site disposal, the wastes generated would be disposed of as RRM at a permitted and licensed facility.

\subsection{NONREGULATORY ACTIVITIES}

\subsubsection{Public involvement process}

DOE encourages public participation, as directed by the Secretary of Energy (DOE, 1994a). Day-to-day operations had been guided by the UMTRA public affairs plan (DOE, 1994b). The DOE-GJPO community relations plan will be used as an interim document for public involvement in the Project. A new UMTRA Ground Water Project public affairs plan will be developed by GJPO.

The goals of the community relations program are to promote public awareness, understanding, and support of the Project, and to maintain a proactive public affairs and community relations program that accurately identifies public/media concerns. The community relations program also establishes public involvement and information activities to promote two-way communication between DOEGJPO and the public (stakeholder involvement).

Frequent oral and written communication with Project stakeholders will be enhanced in addition to evolving and maintaining a proactive outreach program, 


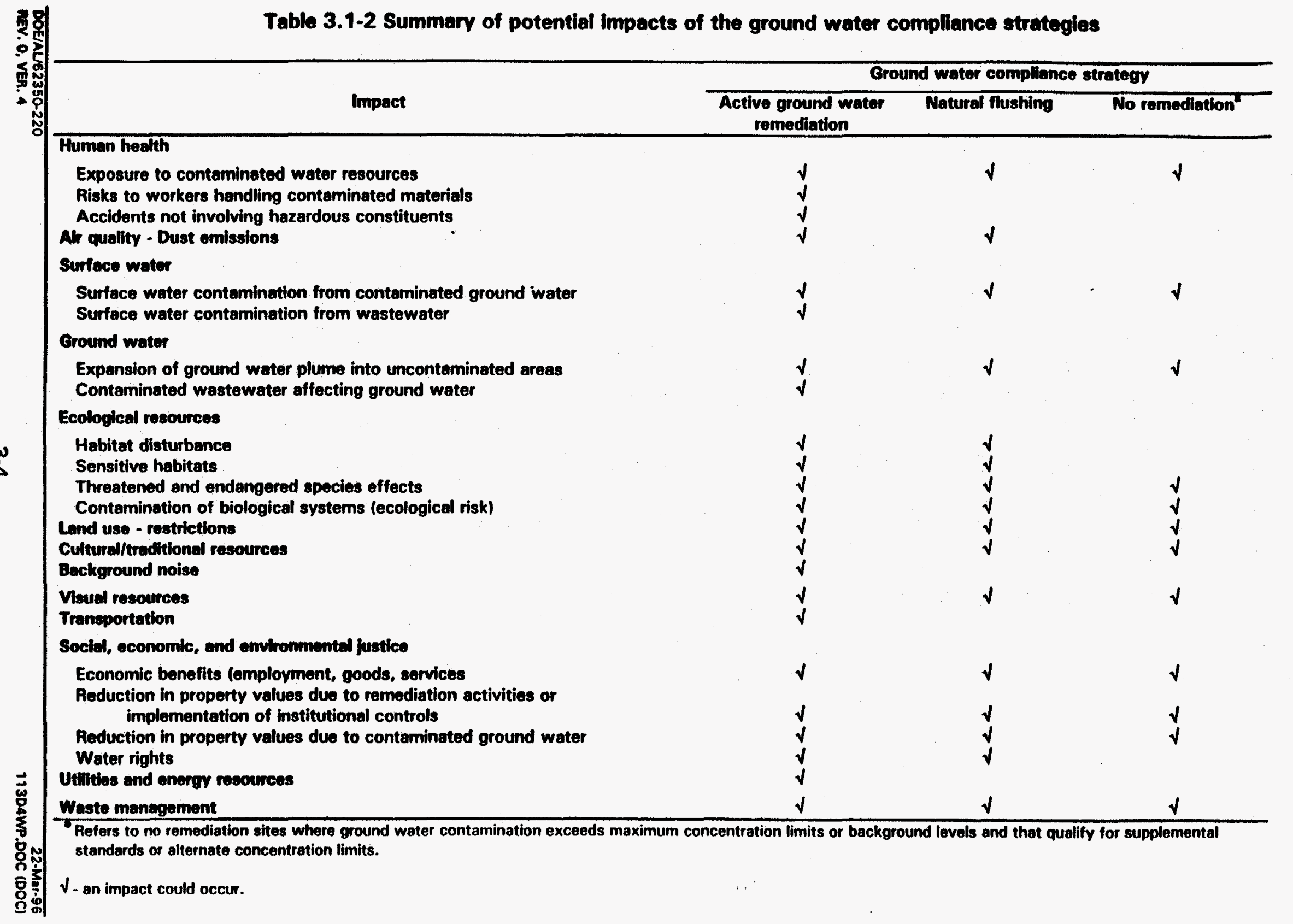


Table 3.2-1 Schoduled cooperative agreements

\begin{tabular}{ll}
\hline \multicolumn{1}{c}{ State/tribal entity } & \multicolumn{1}{c}{ Affected site } \\
\hline State of Colorado & $\begin{array}{l}\text { Maybell, Rifle (2), Grand Junction, Gunnison, Slick } \\
\text { Rock (2), Durango, Naturita }\end{array}$ \\
State of New Mexico & Ambrosia Lake \\
State of Oregon & Lakeview \\
State of Pennsylvania & Canonsburg/Burrell \\
State of Texas & Falls City \\
State of Utah & Salt Lake City, Green River \\
State of Wyoming & Riverton, Spook \\
Hopi Tribe & Tuba City \\
Navajo Nation & Tuba City, Monument Valley, Mexican Hat, Shiprock \\
Northern Arapaho-Shoshone & Riverton \\
Tribes & \\
\hline
\end{tabular}

The state of North Dakota is not included since the designated uranium mill sites at Belfield and Bowman, North Dakota, will not be remediated by DOE since the state of North Dakota has declined to provide its statutorily required cost-share. The state of Idaho is not included because the ground water is not contaminated at the Lowman site. 
which will be key in building stakeholder consensus for the compliance approaches followed by the Project.

\subsubsection{Proaram management}

The DOE-GJPO Manager is authorized to manage and execute Project functions. The Manager is supported by the UMTRA Ground Water Project Manager and other members of the Project team. GJPO manages the Project and its contractors in accordance with overall Project policy and DOE-HQ guidance. GJPO is responsible for the following activities:

- Preparing task orders the new TAR and FOS contractors will manage and control to ensure performance-based support of DOE responsibilities in a cost-effective manner.

- Coordinating activities with Native American tribes, state and local governments, and the public.

- Negotiating cooperative agreements.

- Developing ground water compliance strategies.

- Operating the project control system (PCS).

- Managing the NEPA process.

- Managing the selection and implementation of compliance strategies.

- Initiating procurement for and management of Project contractors.

- Acquiring necessary licenses and permits.

- Complying with the ground water standards as step two of licensing the SIP/SOS sites.

- Complying with regulations and orders.

The GJPO supports the Project in meeting these responsibilities in the areas of procurement, public affairs, quality assurance, property management, legal affairs, health and safety, environment, safeguards and security, finance, and budget. 


\subsection{SITE RELATIVE RANKING}

Since the inception of the Project, several assessments of the relative risks posed by the contaminated ground water at the designated processing sites have been completed. The goal of each assessment was to determine the priorities for implementing ground water remediation. In 1991 the Project prioritized sites using a system heavily weighted on human health risk. This ranking system was used during the PEIS process, with considerable input from stakeholders. The FY1998 budget was prepared based on this prioritization system. Subsequently other ranking systems were applied to the UMTRA sites. In 1995, the ITR recommended a prioritization system based on overall liability, rather than one weighted towards human health risk. In 1996, sites were ranked by the Project following new guidance developed to compare risks among all EM-40 release sites. Table 4.0-1 ranks the UMTRA sites using these three methods. A brief description of the factors considered in each method is provided below.

\subsection{UMTRA PRIORITY CATEGORIZATION}

The 1991 UMTRA Priority Categorization placed the sites in five levels $11=$ highest priority; $V=$ lowest priority) based on the Environmental Restoration Priority System but modified to be specific to the UMTRA Project. Six criteria were used to prioritize the sites: population health risk, individual health risk, environmental risk, timing, socioeconomic impact, and regulatory compliance. Each criterion was scored and weighted, and sites were assigned to one of five categories based on this prioritization system. Specifically, the five categories are described as follows:

Categorv 1 - Sites that require ground water remedial action with the highest current exposure potential or use, anticipated future use, long duration of anticipated remedial action, and/or strong tribal/state interest in seeing the ground water remediated.

Category II - Sites that require ground water remedial action with anticipated or potential future use.

Category III - Sites where remedial action is required, but where the primary consideration is completing required actions in a timely and cost-effective manner.

Categorv IV - Sites where no active remediation activities are anticipated due to expected regulatory relief such as supplemental standards or ACLs. However, there may be some additional data gathering to support the recommendations. These sites were referred to as the "difficult" no-action sites.

Category $V$ - Sites where no active ground water remediation activities are anticipated, and where this can be easily addressed in the PEIS or a similar document. This category would apply at sites where there is no existing ground water contamination or the NRC has already accepted an application for 
Table 4.0-1 Site relative rankings

\begin{tabular}{|c|c|c|c|}
\hline Site & $\begin{array}{l}\text { UMTRA } 1991 \\
\text { priority category }\end{array}$ & $\begin{array}{l}\text { EM relative risk } \\
\text { ranking }\end{array}$ & $\begin{array}{l}\text { ITR liability score } \\
\text { (tier) }^{c}\end{array}$ \\
\hline Ambrosia Lake & $\bar{V}$ & $L$ & $11(2)$ \\
\hline Belfield & IV & $\mathbf{L}$ & $6(2)$ \\
\hline Bowman & IV & $M$ & $9(2)$ \\
\hline Canonsburg & IV & $L$ & $8(2)$ \\
\hline Durango & \| & $M$ & $12(2)$ \\
\hline Falls City & IV & H & $13(2)$ \\
\hline Grand Junction & III & $H$ & $13(2)$ \\
\hline Green River & III & $M$ & $12(2)$ \\
\hline Gunnison & $1^{d}$ & $H$ & $17(1)$ \\
\hline Lakeview & II & $H$ & $14(2)$ \\
\hline Lowman & v & $\mathbf{L}$ & $9(2)$ \\
\hline Maybell & IV & $M$ & $10(2)$ \\
\hline Mexican Hat & v & $H$ & $12(2)$ \\
\hline Monument Valley & $11^{d}$ & $H$ & $18(1)$ \\
\hline Naturita & III & $H$ & $13(2)$ \\
\hline New Rifle & 1 & $H$ & $17(1)$ \\
\hline Old Rifle & 1 & $L$ & $12(2)$ \\
\hline Riverton & 1 & $H$ & $19(1)$ \\
\hline Salt Lake City & III & $M$ & $10(2)$ \\
\hline Shiprock & $\|$ & $H$ & $17(1)$ \\
\hline Slick Rock - NC & III & $M$ & $11(2)$ \\
\hline Slick Rock - UC & III & $\mathbf{L}$ & $10(2)$ \\
\hline Spook & $\mathbf{V}$ & $\mathbf{M}$ & $11(2)$ \\
\hline Tuba City & $\mathbf{I}$ & H & $20(1)$ \\
\hline
\end{tabular}

Based on modified Environmental Restoration Priority System using site-specific data: 1 = highest risk, $V=$ lowest risk (1991).

Based on EM-40 relative ranking evaluation framework using site-specific data: $H=$ high risk, $M=$ moderate risk, $L=$ low risk (1996).

'Based on ITR priority ranking using site-specific composite liability scores: 21 = highest risk, 0 = lowest risk; (1) first tier priority, (2) second tier priority (1995).

The Gunnison category I prioritization did not take into account the subsequent installation of an alternative water supply which resulted in substantially reduced human heath risk. Monument Valley was moved into category I priority to replace Gunnison. 
supplemental standards as a part of the ground water protection strategy for the UMTRA Surface Project (as of 1991).

Since these original classifications were developed, the Project has become more compliance-driven than remediation-driven.

\subsection{ER RELATIVE RISK RANKING}

The second ranking method is the ER relative risk ranking, which is based on a model contained in the relative ranking evaluation framework (DOE, 1995a). This relative risk ranking model includes three factors: source hazard factor, pathway factor, and receptor factor. Through a combination of site characteristics and calculations, each factor is assigned a level llow, medium, or high). The three factors and their levels then are combined to produce an overall relative risk ranking of low, medium, or high for the site. In contrast to the 1991 UMTRA risk categorization, factors such as length of remedial action and local, state, and tribal interest are not factored in.

\subsection{ITR LIABILITY RANKING}

The third ranking method was created by the team that conducted the ITR of the Project during September 1995. This model encompasses seven factors, which cover various areas of "liability": human health risk, contamination on tribal lands, sole source aquifer, off-site plumes, risk of failure of institutional controls, unknowns or serious data gaps, and past implied warranties to stakeholders. Each factor is assigned one of four levels: $3=$ high; $2=$ medium, $1=$ low, and $0=$ none. The scores for the seven factors are summed to give a composite liability score. Six of the sites had total scores ranging from 17 to 20 and they were placed in the first tier of priority. The remaining sites had total scores ranging from 6 to 14 and they were assigned to the second tier of priority.

\subsection{CORRELATION OF RANKING MODELS}

The correlation among the three ranking models is quite good, even though the models were applied at different times and different factors were used to derive the final score. All ITR Tier 1 sites are rated "high" under the EM relative risk ranking method and in either category I or II under the 1991 UMTRA risk ranking method. The rankings developed for the FY1998 risk data sheets (RDS) were not included in the comparison because the RDS ranking was based on qualitative risk estimates for the three compliance strategies rather than sitespecific risks. Using the RDS rankings would roughly result in the active remediation sites and natural flushing sites having medium risk, while the no remediation sites would have low risk.

These site rankings have not been finalized nor have the actual compliance strategies been selected. The framework for selecting the compliance strategy is documented in the PEIS. The ITR team recommended that sites currently 
classified as "No-Further-Action" sites be accelerated and completed more quickly. The ranking of the sites within the Project and how the activities at these sites should be scheduled is a primary focus of the MAP on the Project. Stakeholder input will be sought during this process. 


\subsection{ENVRONMENTAL RESTORATION STRATEGY}

The proposed ER strategy is to conduct the Project using a consistent, objective, risk-based and compliance-driven approach. The preferred alternative would use active, passive, and/or no remediation ground water compliance strategies to meet the EPA ground water standards at the 24 Project sites. The observational method is being utilized to streamline assessment and evaluation of site remediation requirements.

\subsection{KEY ASSUMPTIONS}

Key assumptions for the Project are divided into the following categories: institutional, regulatory compliance, project management, human resources, and site-specific.

\section{Institutional}

As Project stakeholders, the DOE, tribes, states, public, NRC, EPA, and Congress all influence Project policy and conduct.

As Project stakeholders, communities near the UMTRA sites expect timely compliance with the UMTRA standards and equitable treatment.

DOE will negotiate to obtain access to adjacent private properties underlain by ground water contamination plumes.

The public will participate in the development of compliance strategy alternatives for the Project before options are selected for the sites. All affected states and tribes, except Idaho and North Dakota, will participate in completing the cooperative agreements.

As with the UMTRA Surface Project, tribal and state agencies will continue to take an active role in ensuring site compliance. The procedure for obtaining MCLs, ACLs, and supplemental standards will be agreed upon by the tribes, states, DOE, and NRC before the ground water RAP for a site is prepared, if applicable.

\section{Requlatory compliance}

The UMTRCA will continue to be the regulatory driver.

The Project will comply with applicable federal, tribal, state, and local laws and regulations and DOE Orders per the considerations identified in the PEIS response to comments.

No UMTRA Title I sites will appear on the National Priority List or state Superfund lists. 


\section{Project management}

Conceptual recommendations presented by the ITR team will be acceptable to DOE and efforts to create changes to meet the intent of these recommendations will be acceptable to all levels of DOE.

Waste disposal capacity will be available when needed.

The ground water cooperative agreements will be in place in time for scheduled ground water compliance activities.

State funding will be available in a timely manner and at a required level. Contingency plans will be developed to accommodate required actions, when necessary.

The Project will follow the compliance strategy selection framework identified as the proposed action in the PEIS.

\section{Humen resources}

The GJPO will maintain sufficient staff to manage the Project and the work of the contractors.

GJPO will obtain assistance from other government agencies such as the Bureau of Reclamation, as needed.

\section{Site-specific}

The site-specific compliance strategies identified in budget documents are for budget purposes only. They are not intended to preempt the public involvement process or preclude stakeholder input to the final selection of a compliance strategy.

\subsection{STRATEGY FOR REMEDY SELECTION}

The PEIS identifies the proposed action for selecting remedial action on the Project. The approach is to select strategies that ensure protection of human health and the environment by achieving compliance with the EPA ground water standards at the 21 remaining sites (excluding Lowman, Idaho, and Belfield and Bowman, North Dakota) while maximizing cost-effectiveness. The proposed action provides a framework to ensure the final strategy is protective of human health and the environment. The DOE-GJPO also is committed to ensuring protection of human health and the environment from contaminated ground water before final strategy selection through implementation of interim actions.

Figure 5.2-1 shows the proposed action process (logic framework). The framework is a risk-based decision-making process; each step considers 
protection of the public health and the environment in determining the appropriate strategy to meet ground water protection standards.

The first step in the decision-making proces's would be to determine whether the uranium processing activities at a specific site have resulted in ground water contamination that exceeds background levels or MCLs.

If ground water contamination from uranium processing activities exceeds background levels or MCLs, the next step would be to determine whether compliance with the EPA ground water standards could be achieved by applying supplemental standards based on the existence of limited use ground water. If limited use ground water were shown to exist and if supplemental standards were protective of human health and the environment, no site-specific remediation would be required. If limited use supplemental standards were not protective, the next step would be to determine whether ACLs would apply. If ACLs were protective of human health and the environment, ACLs would be applied. If not, it would be necessary to determine whether the contaminated ground water plume would qualify for supplemental standards based on the criterion that remediation would cause more environmental harm than benefit. At some sites where supplemental standards or ACLs may be applied, ground water monitoring and institutional controls may be required to ensure continued protection of human health and the environment. In addition, when limited use ground water applies, supplemental standards shall ensure the current and reasonably projected uses of the affected ground water are preserved.

If supplemental standards would not be protective, the next step would be to determine whether natural flushing would bring the contaminated ground water within MCLs, background levels, or ACLs within 100 years. Natural flushing is a ground water remediation strategy by which natural ground water processes result in compliance with the EPA ground water standards. If it were determined that institutional controls could be maintained during the natural flushing period and that this strategy were protective of human health and the environment, natural flushing would be used.

If natural flushing would not be protective, it would be necessary to determine whether natural flushing in combination with active remediation methods would meet the EPA ground water standards and would be protective of human health and the environment. If so, natural flushing in combination with active remediation methods would be implemented. Combined with natural flushing, active remediation methods could be used for a short time to remove the most contaminated ground water from a restricted area; then natural flushing would be applied. Another option is to use low-operation and low-maintenance active methods such as gradient manipulation or geochemical barriers, in conjunction with natural flushing.

A risk assessment and SOWP may show that natural flushing combined with active remediation would not result in ground water quality that is protective of human health and the environment. If that were the cese, the next step in the 
framework would be to determine whether active ground water remediation techniques would meet the EPA ground water standards and if so to implement these techniques. Several methods of active ground water remediation could be used, including gradient manipulation, ground water extraction, and in situ ground water treatment. The active remediation methods could be used individually or in combination with other cleanup methods. If active remediation resulted in compliance with the EPA standards, remedial action would be complete. If these methods did not result in compliance, supplemental standards based on technical impracticability of remediation would be applied, along with institutional controls where necessary.

Interim actions will be implemented to protect human health and the environment while a final compliance strategy is being evaluated. Interim actions will be implemented, if appropriate, when a reasonable likelihood exists that beneficial uses of the water is or likely will occur during the evaluation phase.

\subsection{REGULATORY ACTIVITY STRATEGY}

The Project is regulated primarily by the NRC in its role as established in the UMTRCA. Individual tribes and states also have authority over various aspects of Project activities. The GJPO will work closely with the NRC, states, and tribes to ensure Project compliance with applicable regulations.

\subsection{NONREGULATORY ACTIVITY STRATEGY}

The Project actively involves the public, seeking their input and keeping them informed at all times. This has been done throughout the PEIS process, and DOE-GJPO will continue to make concerted efforts to improve communication with stakeholders. Following the ITR team recommendation, the Project team will focus on improvement in this area. Section 3.4 discusses the activities associated with this effort.

\subsection{PERFORMANCE MEASURES}

DOE-GJPO staff is developing Project performance measures based on ITR recommendations.

\section{Current performance measures are:}

- Relative risk reduction - The number of sites that can be brought into compliance or that can complete interim actions to reduce risk exposure in any year.

- Relative risk funding trend - The percentage of total funds being used for compliance attainment activities compared to base costs. 
- Program schedule improvement - The potential to complete the Project before the projected FY2014 completion date. 


\section{gure 5.2-1}

\section{Logic Framework}

\section{axis}

Charecterize plume and hydrological conditions using existing dats and new data as required.

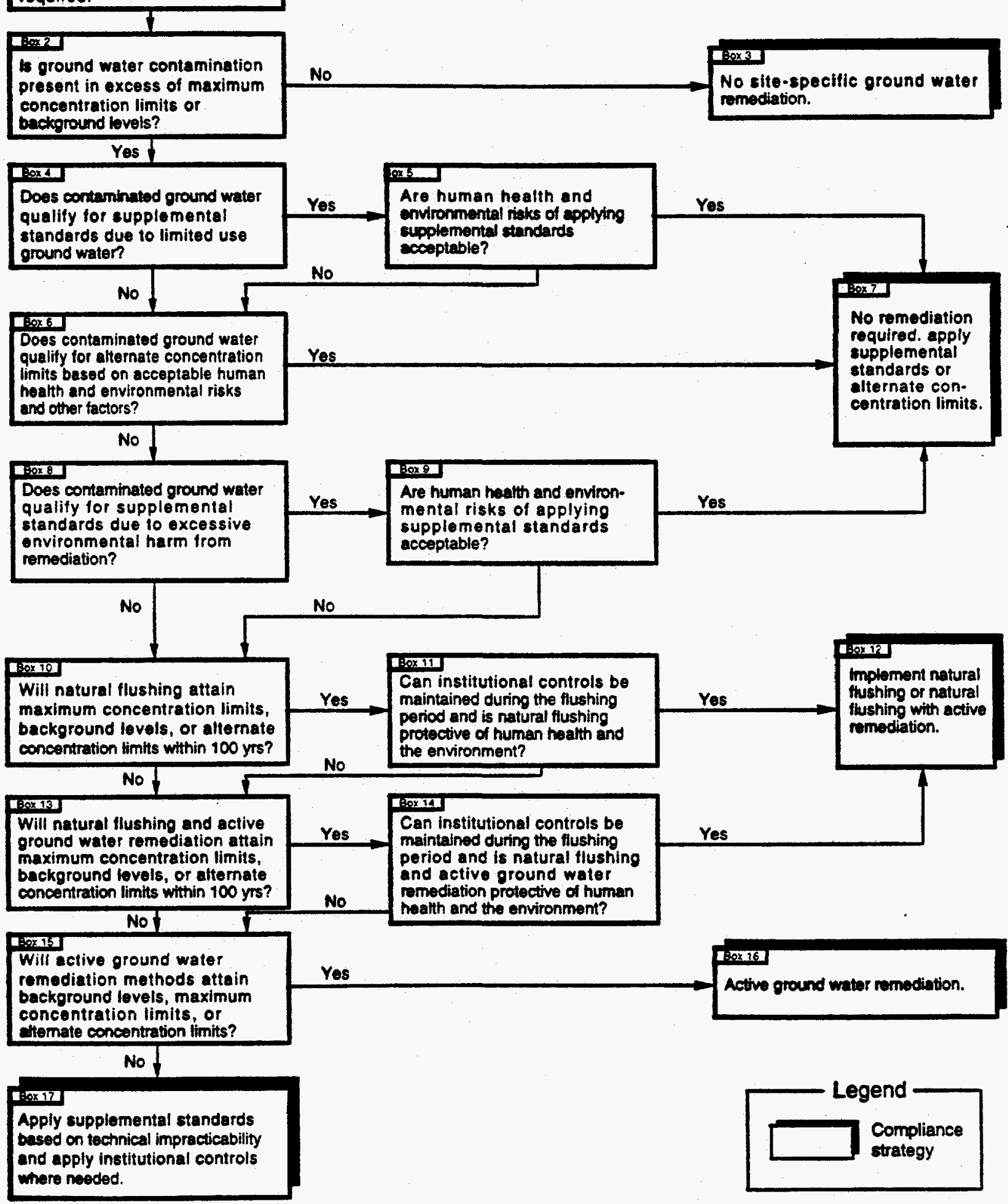

MC. MONSTTE/GMMAPSFLWCHT.A 


\subsection{ENVIRONMENTAL RESTORATION PROGRAM MASTER SCHEDULE}

Figure 6.0-1 lists the major activities by site from FY1996 through FY2011, as scheduled in the FY1998 budget. 
Figure 6.0-1 Ground water summary (FY1998 budget)

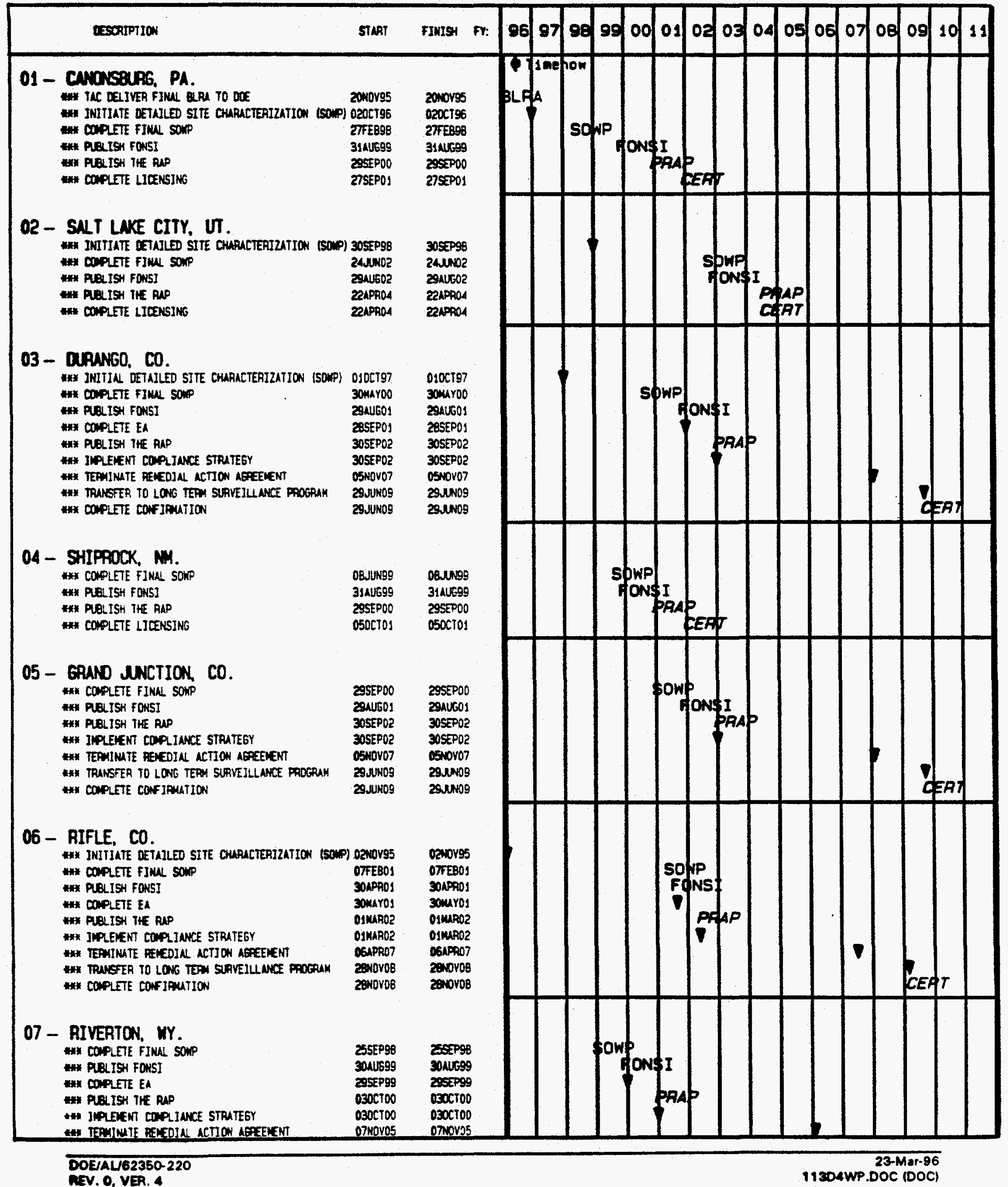


Figure 6.0-1 Ground water summary (Continued)

\begin{tabular}{|c|c|c|c|c|c|c|c|c|c|c|c|c|c|c|c|c|c|c|}
\hline ExRIPIIOA & STAPT & Fints & FY: & as & 97 & e & 99 & 00 & 01 & 02 & 03 : & 04 & os & os & 07 & De: & 09 & 10 \\
\hline 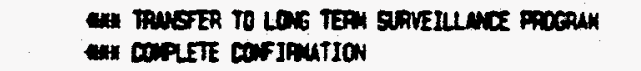 & deut 07 & $\begin{array}{l}\text { cesule7 } \\
\text { oesuler }\end{array}$ & & & & & & & & & & & & & & & & \\
\hline 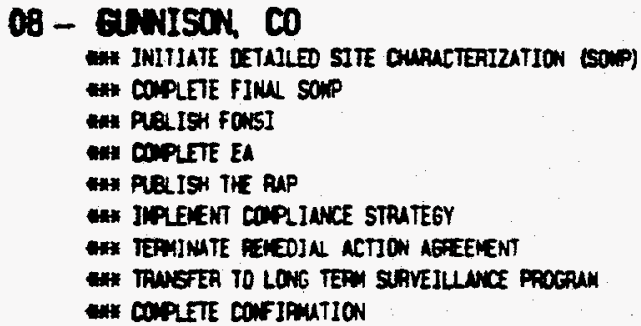 & 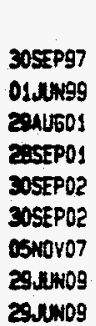 & 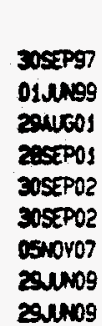 & & & & & & $\mathbf{P}$ & & & & & & & & & & \\
\hline 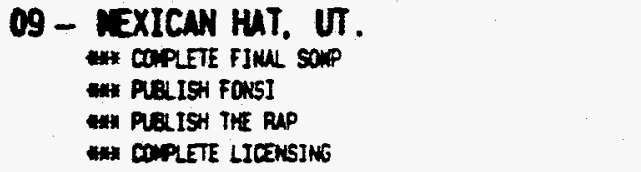 & $\begin{array}{l}\text { 10APR97 } \\
\text { O7ALES97 } \\
\text { 30BEC98 } \\
\text { 200EC99 }\end{array}$ & 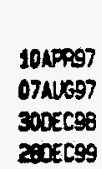 & & & & & & & & & & & & & & & & \\
\hline 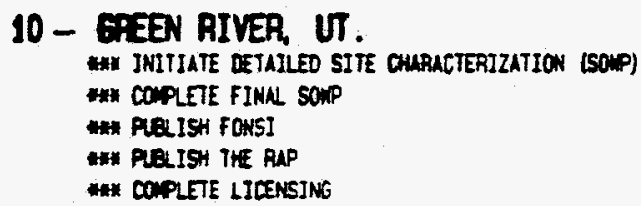 & 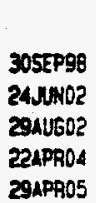 & 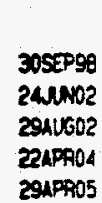 & & & & & & & & & & & & & & & & \\
\hline 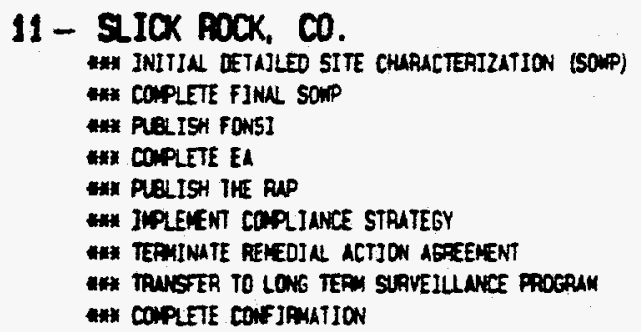 & 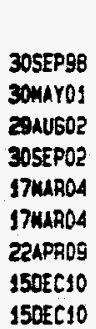 & 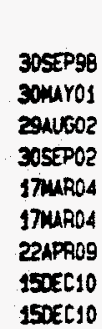 & & & & & & & & & & & P & & & & 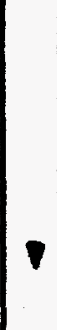 & \\
\hline 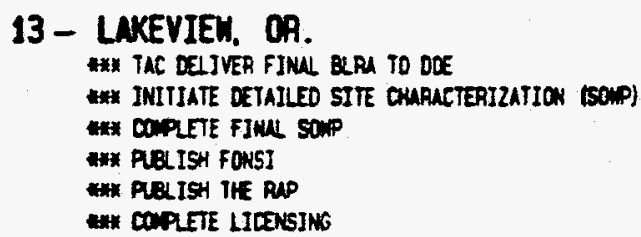 & 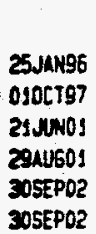 & 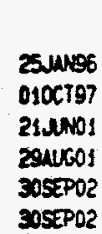 & & & A & & & & & & $P F$ & & & & & & & \\
\hline 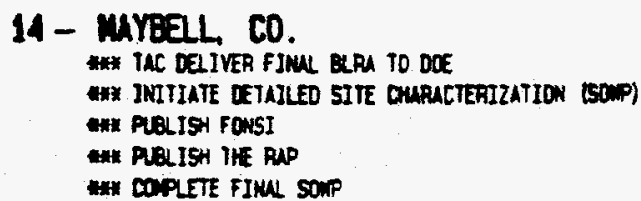 & $\begin{array}{l}2005 C 95 \\
010 C 797 \\
3140698 \\
305 E P 99 \\
17 F E B D 0\end{array}$ & 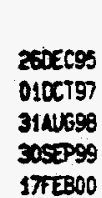 & & & & & & & & & & & & & & & & \\
\hline 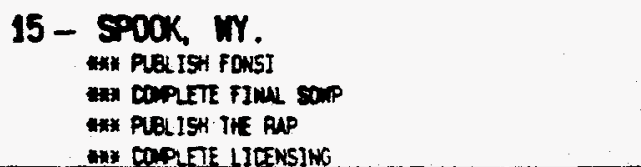 & $\begin{array}{l}\text { 09APR97 } \\
\text { REAY97 } \\
\text { 305EP97 } \\
\text { 20SEP98 }\end{array}$ & 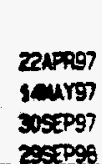 & & & & & & & & & & & & & & & & \\
\hline
\end{tabular}

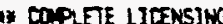


Figure 6.0-1 Ground water summary (Concluded)

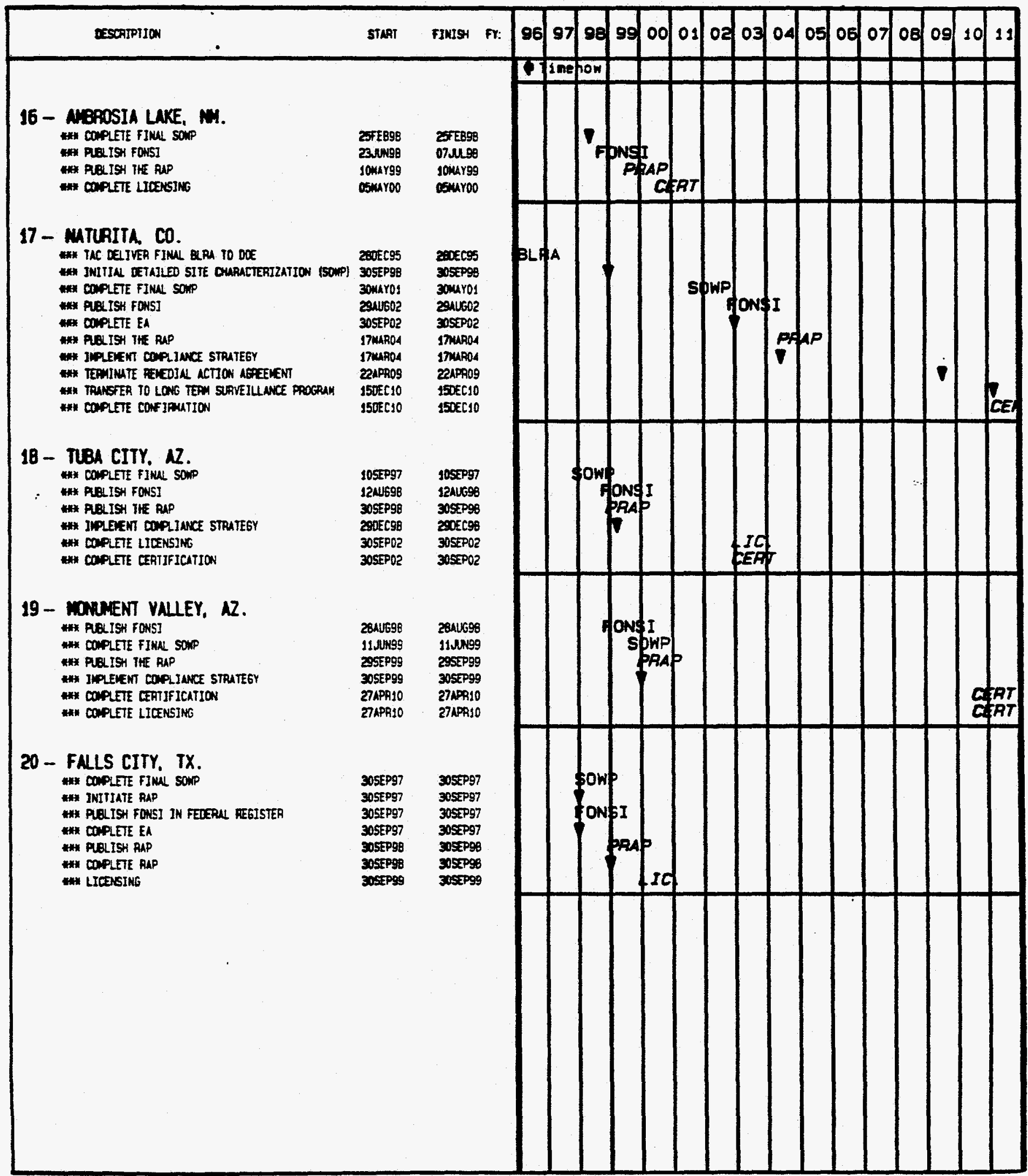




\subsection{ISSUES TO BE RESOLVED}

This section identifies the specific technical and administrative issues facing the Project, and eddresses the major ITR recommendations.

- Continued active implementation of ITR recommendations. Table 7.0-1 lists some of the major ITR recommendations, proposed actions to meet these recommendations, and scheduled initiation dates. Details to implement these proposed actions will be developed during July to October 1996 with the new TAR contractor at GJPO.

- Viability of budgeted compliance approaches for individual sites. The current budgets list compliance strategies for the sites that are "penciled in" based on available information. The site-specific acceptability and viability of these approaches has yet to be determined.

- Project cooperative agreements. These agreements will be revised for the Project with the respective tribes and states. Progress is being made in this area and a draft model cooperative agreement is in preparation.

- Detailed assessment, monitoring, and identification of constituents of concern. These activities and the establishment of ground water standards may be required at VPs with significant potential for ground water contamination.

- Use of Project funds to develop innovative technologies. The Project currently is funding activities at two universities and two national laboratories. Due to the compliance attainment orientation of the Project, these technologies may not be warranted. This issue will receive significant attention during the MAP review phase in response to the ITR team recommendations. An evaluation process to consider the merit of innovative technology expenditures will be made based on sound business management practice during FY 1996.

- Need to determine which costs will be cost shared by the states. A draft position paper has been developed by DOE-GJPO on this issue. UMTRA reauthorization may include considerations in regard to this item as recommended by the Government Accounting Office report (DOE, 1995b). 
Table 7.0-1 Recommendations and proposed actions

\begin{tabular}{l} 
TTR major recommendation \\
\hline 1. Adopt vision statement. \\
2. Reengineer program strategy to \\
have active remediation periods \\
managed as projects and \\
monitoring periods as programs.
\end{tabular}

3. Transition activities should be complete by the end of FY1996.

4. Regulatory strategy.

5. Establish policy on baseline human health risk assessment.

6. Formal prioritization system.

7. Implement interim strategies.

\section{GJPO proposed oction}

Adopt mission statement.

Site-specific tasks will be performed as projects.

Programmatic activities will be performed as program (i.e., project managernent, public relations, database management).

Specific GJPO action identified in Interim Action Plan, 22 February 1996.

Develop consistent strategy from site to site that considers regulatory compliance but includes a larger reliance on liability reduction.

Use of BLRAs will be consistent with regulatory requirements to determine riskbased cleanup levels in absence of MCLs.

Develop/document prioritization system incorporating risk analysis as one liability parameter.

Reduce potential for complete pathways by placing strategic water supplies or active interim measures to contain source of contamination as identified in recommendation No. 8 below. Develop short-term action plan for sites with emphesis on immediate reduction of liabilities.
Status of proposed action

Completed, Straw Document

A reviaw of the project manegement approach is ongoing. The steps to implement the proposed action will be completed by July 1996.

Transition will be complete by the end of FY1996.

Strategy will be established by July 1996.

All BLRAs will be completed in FY1996.

Programmatic evaluation of the project priorities are being reeveluated in FY1896. The 1991 ER modified prioritization, the ITR-recommended prioritization, and the relative risk criteria will be considered in this re-evaluation. Final recommendations will be openly discussed with the public.

Discussion on the potential to supply alternate water systems on two sites (Riverton and Rifle) are ongoing as identified in the ITA Interim Action Plan. Review of additional interim action opportunities at other sites will be completed by the middle of FY1997. 
Table 7.0-1 Recommendations and proposed actions (Continued)

\begin{tabular}{l} 
Th major rocommendetion \\
\hline 8. Etablish interim actions to \\
contain the source of continuous \\
oround water contemination.
\end{tabular}

9. Develop organic constituents (LNAPL) identification procedures.

10. Syatematic program of fate and transportation modeling should be used to evaluate natural flushing strategy. Develop an institutional controis $(\mathrm{IC})$ and modeling appraisal system.
C.JPO proposed action

Completion of the removal or stabilization of tailings under the Surfece Project has stabilized the contamination source. Opportunities for interim actions will be determined during an evaluation of interim actions during Phase $I$ of the Project.

Complete initial field Investigation at Rifle. Survey available process records, interview personnel, determine physical properties, and determine quantities/concentrations released to environment and fate of contaminants. Incorporate data collection setivities accordingly.

Develop a systematic fate and transport modeling program, which can quickly establish the feasibility of natural flushing meeting the EPA standards within 100 years.
11. Transient drainage dovelopment.

12. Documentation and technical work flow procedures should be modified as shown in ITR report.
Develop strong technical besis to evaluate transient drainage and stoady-state flux. Institute interim measures as necessary.

Develop procedures for moving sites through DOO process and through to closure.
Status of proposed ection Discussion on the potential to supply altemate water systems on two sites (Riverton and Fiflel are ongoing as identified in the ITR Interim Action Plan. Review of additional interim action opportunities at other sites will be completed by the middle of FY1997.

A small field investigation at Rifle is being completed as identified in the Interim Action Plan. Data from this investigation will be compiled by June 1996 and based on these findings additional work scope to moet the proposed action will be developed in FY1997.

Sandia National Laboratories has been tasked to utilize the Borehole Optimization Support System (BOSS) computer application to perform evaluations of the probability of natural flushing being successful at seven proposed sites. Completion of this task is scheduled for July 1996. A review of the ability of local, state, and tribal entities to implement Institutional Controls to restrict access to ground water will be completed by the end of FY1997. Initial Discussions on institutional controls (IC) with the states of Utah, Wyoming, and Colorado have already taken place. Also, initial discussions have taken place with the Shoshone and Arapaho Tribes and the city of Rifle, Colorado, on their legal abilities to implement ICs.

Initiate ection plan on or before November 1996, in coordination with the UMTRA Surface Project.

Proposed action will be developed on or before August 1996. 
Table 7.0-1 Recommendations and proposed actions (Continued)

TTh mojor recommendetion

13. Develop a firm scientific besis for innovative technologies.

14. Concept - test transition plume remediation strategy.

15. Compliance procedures and strategies.

16. DOE staff complete 25-page EAs for four easy sites during the transition period.
G.PO proposed ection

Provide firm scientific basis to evaluate remediation alternatives and innovative technologies. Evaluation will include project needs, time for implementation, and potential cost sevings, etc.

Establish technology policies for approaching scale-up eystematically.

Evaluate/develop strategy.

Develop procedures/policies regarding NRC compliance and approval with emphasis on reducing short-term and longterm liabilities. Implement interim remedial measures/construction of alternate water systems as appropriate. Complete briefings with regulators and stakeholders to explain change to approach.

As identified in the Interim Action Plan, one 25-page or less EA for the Spook, WY, site will be developed as a model for future EAs. The ability to complete other low priority EAs will be evaluated after this model is completed, which will occur after the completion of the final PEIS.
Btatus of proposed action

GJPO is working with Sandia National Leboratories to develop a decision tree to evaluate the merits of innovative technologies based on commercial considerations. Additionally, innovative technologies presently being funded by the UMTRA Ground Water Project will be rigorously examined in FY1996.

No action to date; initiate action plan on or before October 1996.

An initial meoting with NRC was held on 14 February 1996 to discuss regulatory fremework and coordination efforts. Discussions on two alternate water supply systems (Rifle and Riverton) with stakeholders have been initiated, es identified in ITR Interim Action Plan. A firm management commitment to a more aggressive approach to reduction of liabilities as recommended by the ITR team will be stressed at all opportunities.

The draft EA for Spook. Wyoming, will be complete on or before 31 March 1996. A schedule for completion of this document and the other three EAs identified will be completed directly after the PEIS and ROD are completed. 
Table 7.0-1 Recommendations and proposed actions (Concluded)

\section{TR major recommendation}

17. Use commercial-like manegement structure. With this structure change, the DOE team also must change the relationship with the TAC contractor from one of "teammate" to one of "customer-contractor."

18. The ITR team's recommended organizational structure for the UMTRA Ground Water Project is shown in Figure 8.5.1 of their report.

\section{CJPO proposed action}

The first action which has been completed is to establish a "customer-contractor" relationship. Firm schadules, costs, and deliverables for the TAC to complete in FY1996 have been developed to meet specific DOE project needs. The GJPO is awarding two new performance-based contractors in mid-1996. The UMTRA Ground Woter Project is within the Technical Assistance and Remediation (TAR) contract.

As established in the Interim Action Plan, the GJPO fully supports the concepts identified in the ITR commerciel-like structure. The GJPO's management structure is very similar to the ITRrecommended structure. The ITR recommendation to have six additional contracts beyond the TAR contract for specific tasks for the UMTRA Ground Water Project will not be directly implemented.

However, to the greatest extent possible, the TAR contractor will be managed by DOE incentives to setup basic ordering agreements (BOA) to accomplish specific, defined tasks.

\section{Status of proposed ection}

Procurement action is ongoing for the TAR contract. Contract edministration will be tailored to meet the intent of the ITR recommendation to the greatest extent possible.

The GJPO's organizational structure is identified in Section 1.6 of this MAP, which is very similar to the ITR team recommendation; the exception being the use of multiple contrectors directly contracted to DOE. 


\subsection{REFERENCES}

DOE (U.S. Department of Energy), 1996. Fina/ Management Action Process (MAP) Resource Guide, prepared for the U.S. Department of Energy, Office of Environmental Restoration, EM-40.

DOE (U.S. Department of Energy), 1995a. Relative Ranking Evaluation Framework for EM40 Release Sites, Facilities, and Buildings, draft, 22 December 1995, U.S. Department of Energy, Office of Environmental Restoration.

DOE (U.S. Department of Energy), 1995b. Uranium Mill Tailings Cleanup, Continuous But Future Costs Are Uncertain, GAO/RCEO-96-37, December.

DOE (U.S. Department of Energy), 1994a. Guidance for Implementation of the Department's Public Participation Policy, memorandum from the Secretary of Energy, U.S. Department of Energy, Washington, D.C.

DOE (U.S. Department of Energy), 1994b. Public Affairs Plan, DOE/AL/62350-154, Rev. 0 , prepared for the U.S. Department of Energy, UMTRA Project Office, Albuquerque Operations Office, Albuquerque, New Mexico.

TAC (Technical Assistance Contractor), 1995. Contaminated Ground Water, Volume Calculation (Output), UPDCC File Location No. 0.16.1.

\section{CODE OF FEDERAL REGULATIONS}

10 CFR Part 40, Domestic Licensing of Source Material, U.S. Nuclear Regulatory Commission.

40 CFR Part 192, Health and Environmental Protection Standards for Uranium and Thorium Mill Tailings, U.S. Environmental Protection Agency.

40 CFR Part 1500, "Regulation for Implementing the Procedural Provision of the National -Environmental Policy Act," Council on Environmental Quality (1994).

40 CFR Part 1500, Purpose, Policy, and Mandate, Council on Environmental Quality.

40 CFR Part 1501, NEPA and Agency Planning, Council on Environmental Quality.

40 CFR Part 1502, Environmental Impact Statement, Council on Environmental Quality.

40 CFR Part 1503, Commenting, Council on Environmental Quality.

40 CFR Part 1504, Predecision Referrals to the Council of Proposed Federal Actions Determined to Be Environmentally Unsatisfactory, Council on Environmental Quality. 
40 CFR Part 1505, NEPA and Agency Decisionmaking, Council on Environmental Quality.

40 CFR Part 1506, Other Requirements of NEPA, Council on Environmental Quality.

40 CFR Part 1507, Agency Compliance, Council on Environmental Quality.

40 CFR Part 1508, Terminology and Index, Council on Environmental Quality.

60 FR 2854. Groundwater Standards for Remedial Actions at Inactive Uranium Processing Sites, final rule, U.S. Environmental Protection Agency, 11 January 1995.

\section{UNITED STATES CODE}

42 USC $\$ 4321$ et seq., National Environmental Policy Act, 1 January 1970.

42 USC $\$ 7901$ et seq., Uranium Mill Tailings Radiation Control Act, 8 November 1978.

42 USC 7922 et seq., Uranium Mill Tailings Remedial Action Amendments Act, 5 November 1988. 
APPENDIX A

FISCAL YEAR FUNDING REQUIREMENTS 
$$
\text { - }
$$ 
APPENDIX A

UMTRA GROUND WATER FY 1998 FIELD BUDGET

Escalated totals by Site by Year in \$K

\begin{tabular}{|c|c|c|c|c|c|c|c|c|c|c|c|}
\hline \multirow{4}{*}{ 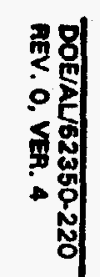 } & \multicolumn{11}{|c|}{ Escalated totals by Site by Year in $\$ K$} \\
\hline & Sthe & $\begin{array}{l}\text { Prior Years } \\
\text { 1991-1995 }\end{array}$ & 1996 & 1997 & 1998 & 1998 & 2000 & 2001 & 2002 & $\begin{array}{l}\text { Remalning } \\
\text { 2003-2011 }\end{array}$ & Total \\
\hline & Ambrosia Lake & 348.54 & 5.15 & 15.51 & - & 227.07 & 71.43 & 24.46 & 28.87 & 113.48 & 834.51 \\
\hline & Belfield(a) & 266.22 & - & - & - & - & - & - & - & - & 266.22 \\
\hline & Bowman(a) & 254.98 & (5.94) & - & - & - & - & - & - & - & 249.04 \\
\hline & Canonsburg & 825.83 & 22.99 & 148.37 & 85.61 & 127.44 & 140.10 & 76.79 & 29.03 & 114.56 & $1,570.72$ \\
\hline & Durango & $1,077.98$ & 29.40 & 12.14 & 310.67 & 696.13 & 405.45 & 422.74 & 849.92 & $1,728.51$ & $5,532.94$ \\
\hline & Falls City & $1,171.62$ & 159.60 & 182.72 & 171.68 & 129.07 & 52.03 & 33.08 & 39.02 & 154.45 & $2,093.27$ \\
\hline & Grand Junction & 533.83 & 57.21 & 121.62 & 359.43 & 282.06 & 489.92 & 309.13 & 708.61 & $1,801.83$ & $4,663.64$ \\
\hline & Green River & 610.93 & 3.28 & 9.62 & - & 348.68 & 758.90 & 583.60 & 566.31 & 854.88 & $3,736.20$ \\
\hline & Gunnison & 719.56 & 6.93 & 20.53 & 468.52 & 455.30 & 218.73 & 430.51 & 842.07 & $1,887.45$ & $5,049.60$ \\
\hline & Lakeview & 655.85 & 9.16 & 14.33 & 163.00 & 633.87 & 555.53 & 393.31 & 494.22 & $1,674.55$ & $4,593.82$ \\
\hline & Lowman(a) & 212.51 & 3.98 & - & - & - & - & - & - & - & 216.49 \\
\hline & Maybell & 388.94 & 6.59 & 20.67 & 497.05 & $1,086.11$ & 139.45 & 31.32 & 36.96 & 146.34 & $2,353.43$ \\
\hline & Mexican Hat & 315.97 & 44.60 & 92.71 & 44.39 & 216.28 & 169.75 & 66.05 & 33.74 & 134.40 & $1,117.89$ \\
\hline & $\begin{array}{l}\text { Monument } \\
\text { Valley }\end{array}$ & 681.13 & 110.27 & 535.88 & 662.57 & $1,866.40$ & $10,698.88$ & $25,716.20$ & $4,700.34$ & $32,255.37$ & $77,227.04$ \\
\hline & Naturita & 285.20 & 7.51 & 22.03 & - & 463.10 & 792.21 & 403.25 & 615.46 & $3,557.88$ & $6,146.64$ \\
\hline & Rifie & 825.43 & 101.53 & 160.71 & 482.76 & 285.71 & 465.18 & 640.72 & 543.22 & 2.155 .12 & $5,660.38$ \\
\hline & Riverton & $2,492.64$ & 416.50 & 201.83 & 467.66 & 439.34 & 631.42 & 199.54 & 230.89 & $1,485.48$ & $6,565.30$ \\
\hline & Salt Lake City & 545.75 & 85.13 & 65.87 & 71.83 & 236.65 & 639.62 & 441.73 & 401.12 & 537.07 & $3,024.77$ \\
\hline & Shiprock & $2,499.61$ & 444.33 & 922.61 & 338.22 & $1,093.52$ & 505.22 & 266.15 & 344.46 & $1,359.41$ & 7.773 .53 \\
\hline & Slick Rock & 629.46 & 3.97 & 134.28 & 32.82 & 323.25 & 656.89 & 392.57 & 602.90 & $3,073.04$ & $5,849.18$ \\
\hline & Spook & 333.09 & 27.71 & 156.91 & 65.33 & 43.24 & 51.49 & 32.73 & 38.62 & 152.23 & 901.35 \\
\hline & Tuba City & $1,823.66$ & 434.87 & $1,038.66$ & $2,048.73$ & $11,480.20$ & $7,077.72$ & $7,083.65$ & $8,584.09$ & $27,747.70$ & $67,319.28$ \\
\hline & Nonsite & $2,978.43$ & $5,826.53$ & $3,932.11$ & $2,461.37$ & $4,934.89$ & $12,085.43$ & $4,342.15$ & $9,870.73$ & $50,347.65$ & $96,779.29$ \\
\hline & Total & $20,477.16$ & $7,801.30$ & $7,809.11$ & $8,731.64$ & $25,368.31$ & $36,605.35$ & $41,889.68$ & $29,560.58$ & $131,281,40$ & $309,524.53$ \\
\hline \multirow{3}{*}{ 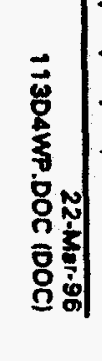 } & State share & - & 1.30 & 9.11 & 20.67 & 36.38 & 51.49 & 40.68 & 247.27 & 653.87 & $1,060.77$ \\
\hline & Federal share & $20,477.16$ & $7,800.00$ & $7,800.00$ & $8,710.97$ & $25,331.93$ & 36.553 .86 & $41,849.00$ & $29,313.31$ & $130,627.53$ & $308,463.76$ \\
\hline & Project & if lis & & 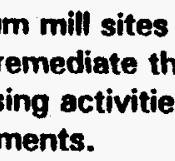 & & & & & & & 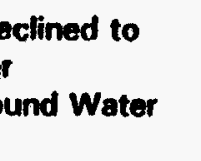 \\
\hline
\end{tabular}





\section{APPENDIX B}

MAJOR ENVIRONMENTAL RESTORATION DOCUMENTS 
Table B-1 Major programmatic documents

\begin{tabular}{|c|c|c|c|}
\hline Title & Date & Phase & $\begin{array}{c}\text { Applicable } \\
\text { site }\end{array}$ \\
\hline Programmatic Environmental Impact Statement & 1/96 & Planning & All sites \\
\hline FY1993 Annual Environmental Report & $10 / 94$ & Monitoring & All sites \\
\hline FY1994 Annual Environmental Report & 8/95 & Monitoring & All sites \\
\hline $\begin{array}{l}\text { Ground Water Protection Management Program } \\
\text { Plan }\end{array}$ & $2 / 94$ & Planning & All sites \\
\hline Environmental Protection Implementation Plan & $10 / 94$ & Planning & All sites \\
\hline Technical Approsch to Ground Water Restoration & $91 / 93$ & Planning & All sites \\
\hline Ground Water Project Plan & $9 / 94$ & Planning & All sites \\
\hline Quality Assurance Program Plan & $9 / 95$ & Planning & All sites \\
\hline $\begin{array}{l}\text { Waste Minimization and Pollution Prevention } \\
\text { Awareness Program Plan }\end{array}$ & $7 / 94$ & Planning & All sites \\
\hline Environmental Monitoring Plan & $12 / 92$ & Planning & All sites. \\
\hline Ground Water Monitoring Program Plan & $5 / 92$ & Planning & All sites \\
\hline Environment, Safety, and Health Plan & $3 / 95$ & Planning & All sites \\
\hline UMTRA Water Sampling Handbook & $8 / 94$ & Monitoring & All sites \\
\hline $\begin{array}{l}\text { Guidance Document for Preparing Water } \\
\text { Sampling and Analysis Plans }\end{array}$ & $8 / 93$ & Planning & All sites \\
\hline Human Heaith Risk Assessment Methodology & $11 / 94$ & Assessment & All sites \\
\hline Planning Guide for Site Observational Work Plans & $7 / 95$ & Plenning & All sites \\
\hline Quality Assurance Implementation Plan & $9 / 94$ & Pianning & All sites \\
\hline $\begin{array}{l}\text { Technical Approach for the Management of } \\
\text { UMTRA Ground Water Investigation-Derived } \\
\text { Wastes }\end{array}$ & $2 / 94$ & Planning & All sites \\
\hline
\end{tabular}


Table B-2 Major site-specific documents

\begin{tabular}{|c|c|c|c|c|c|}
\hline SITE & RAP & NEPA & WSAP & BLRA & SOWP \\
\hline Ambrosia Lake & $2 / 91 \mathrm{~F}$ & $6 / 87 \mathrm{~F}$ & $1 / 94$ & & 2/95 Rev. 0 \\
\hline Belfield & $10 / 90 \mathrm{PF}$ & 9/93 F & $9 / 94$ & 9/94 F Rev.1 & \\
\hline Bowman & $10 / 90 \mathrm{PF}$ & 9/93 F & 9/94 & 11/94 F Rev.0 & \\
\hline Canonsburg & $10 / 83 \mathrm{~F}$ & $7 / 83 \mathrm{~F}$ & $9 / 95$ & 11/95 F Rev.1 & \\
\hline Durango & $12 / 91 \mathrm{~F}$ & $10 / 85 \mathrm{~F}$ & $9 / 95$ & 9/95 F Rev.1 & \\
\hline Falls City & $9 / 92 \mathrm{~F}$ & $12 / 91 \mathrm{~F}$ & $9 / 95$ & 9/95 F Rev.1 & 6/95 Rev.0 \\
\hline Grand Junction & $9 / 91 \mathrm{~F}$ & $12 / 86 \mathrm{~F}$ & $8 / 95$ & 9/95 F Rev.2 & 3/96 Rev.0 \\
\hline Green River & $3 / 91 \mathrm{~F}$ & $7 / 88 \mathrm{~F}$ & $8 / 95$ & 9/95 F Rev.1 & \\
\hline Gunnison & $10 / 92 \mathrm{~F}$ & $2 / 92 F$ & 9/95 & 4/94 F Rev.1 & \\
\hline Lakeview & $7 / 92 \mathrm{~F}$ & $4 / 85 F$ & 9/95 & 3/96 F Rev.1 & \\
\hline Lowman & $9 / 91 \mathrm{~F}$ & $1 / 91 F$ & & & \\
\hline Maybell & $6 / 94 F$ & $11 / 94 \mathrm{~F}$ & $6 / 94$ & 3/96 F Rev.1 & \\
\hline Mexican Hat & $2 / 93 F$ & $10 / 87 \mathrm{~F}$ & $9 / 95$ & & 9/95 Rev.0 \\
\hline Monument Valley & $2 / 93 F$ & $6 / 89 \mathrm{~F}$ & $9 / 95$ & 3/96 F Rev. 1 & 3/96 Rev.0 \\
\hline Naturita & $3 / 94 \mathrm{~F}$ & $10 / 94 F$ & $9 / 95$ & 11/95 F Rev.1 & \\
\hline New Rifle & $8 / 91 \mathrm{~F}$ & $3 / 90 \mathrm{~F}$ & $9 / 95$ & 8/95 F Rev.1 & 3/96 Rev.0 \\
\hline Old Rifle & $8 / 91 \mathrm{~F}$ & $3 / 90 \mathrm{~F}$ & $9 / 95$ & 8/95 F Rev.1 & 3/96 Rev.0 \\
\hline Riverton & $10 / 87 \mathrm{~F}$ & $6 / 87 F$ & $4 / 94$ & 9/95 F Rev.1 & 3/95 Rev.0 \\
\hline Salt Lake City & $12 / 84 F$ & $7 / 84 F$ & $9 / 95$ & 9/95 F Rev.1 & \\
\hline Shiprock & $7 / 93 \mathrm{~F}$ & $5 / 84 F$ & 9/95 & 4/94 F Rev.1 & 7/95 Rev.0 \\
\hline Slick Rock - NC & $9 / 95 \mathrm{~F}$ & $5 / 95 F$ & 9/94 & 9/95 F Rev.1 & \\
\hline Slick Rock - UC & $9 / 95 \mathrm{~F}$ & $5 / 95 F$ & 9/94 & 9/95 F Rev.1 & \\
\hline \multirow[t]{2}{*}{ Spook } & $7 / 89 \mathrm{~F}$ & $4 / 89 \mathrm{~F}$ & $3 / 94$ & & 4/95 Rev.0 \\
\hline & & $3 / 96 D^{2}$ & & & \\
\hline Tuba City & $8 / 89 \mathrm{~F}$ & $11 / 86 \mathrm{~F}$ & 2/96 & 6/94 F Rev. 0 & 7/95 Rev.0 \\
\hline
\end{tabular}

"Ground Water Project environmental assessment.

F - final; PF - preliminary final; D - draft.

RAP - Surface Project remedial action plan (no Ground Water Project RAP to date).

WSAP - water sampling and analysis plan.

BLRA - baseline risk assessment.

SOWP - site obervational work plan.

NEPA - Surface Project National Environmental Policy Act document. 
APPENDIX C

DECISION DOCUMENT RECORD OF DECISION SUMMARIES 
At this early stage in the Uranium Mill Tailings Remedial Action Ground Water Project, there are few final decision documents because most sites are still in the planning or characterization phases.

The final Surface Project remedial action plan for the Lowman, Idaho, site declared that ground water contamination did not result from uranium processing activities. The U.S. Nuclear Regulatory Commission concurred that no further action was required under the UMTRA Ground Water Project to complete the licensing requirements for the site (see Exhibit Al.

The programmatic environmental impact statement record of decision for the programmatic environmental impact statement is expected to be published in the Federal Register during fiscal year (FY) 1996. This decision will result in the selection of the framework for conducting the UMTRA Ground Water Project 
This page intentionally left blank. 


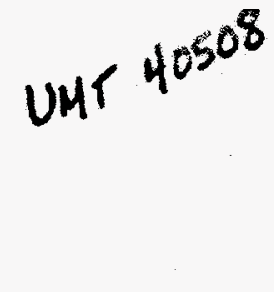

NRC/UmT/O PQR 0056

NUCLEAR REGULATORY COMMISSION

washinetoN, D. e. exass

JUL $\$ 1991$

Mark L. Matthews, Project Manager

Uranium Mill Taliings Remedial Action

Project office

U.S. Department of Energy

Albuquerque Operations Office

P.0. Box 5400

Albuquerque, New Mexico 87115

Dear Mr. Matthews:

The U.S. Nuclear Regulatory Comnission (NKC) staff has completed its review of the final Remedial Action Plan and Site Design (RAP) and all associated documentation pertinent to the proposed remedial action for the uranium mill tailings site at Lowman, Idaho. Our review is documented in the Final Technical Evaluation Report (TER) (see Enclosure 1), which discusses the NRC staff's evaluation of the remedial action for compliance with the EYA standards.

In the groundwater area, the Lowman site is unique in that it does not have the outstanding open issue of postponed groundwater cleanup as resuit of DOE's ability to demonstrate a lack of groundwater contamination at the site. Therefore, based on our review, the NRC can give full concurrence in the final Lowman Remedial Action Plan and Site Design. As a result, I have signed the original signature pages transmitted to the NRC for signature with Revision 3 to the RAP. The completed signature pages for the RAP are included as Enclosure 2 .

DOE submitted RAP Modification (RAP MOD) No. 1 as Revision 2 to the RAP on April 22, 1991, for NRC staff review and concurrence. The RAP MOD requested the use of supplemental standards to prevent excessive environmental harm from the removal of residual radioactive material in the proposed remedial action for Lowman. Ihe NRC staft reviewed and concurred in this RAP MOD on June 18, 1991. Our review of this RAP MOD has also been documented in the final TER and the signature pages for the RAP MUD are provided in Enclosure 3.

As you are aware, DOE also recently submitted to the NRC Revision $B$ to the Remedial Action Inspection Plan (RAIP) (June 24, 1991) for review and concurrence; and two Project Interface Documents Nos. 12-5-04 and 12-5-05 (June 11, 1991) for review. As result of our review of these documents, the NRC staff concurs in the RAIP and is in agreement with the classification of the PID No. 12-5-04. The staff, however, does not agree with the Category II classification of PID No. 12-5-05 and wili provide a complete discussion of our evaluation under separate cover at later date. 
If you have any questions regarding the information in the enclosed final TER, please contact me at FTS $492-3439$ or the NRC Project Manager, S. L. Wast ler, at FTS $492-0582$.

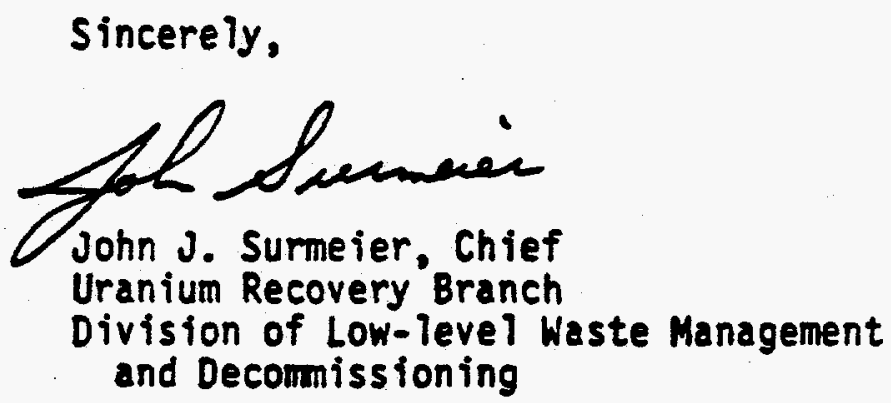

Enclosures: As stated

cc: P. Mann, DOE/AL

M. Abrams, DOE/AL

R. Donovan, Idaho

C. Cody, Idaho

K. Feldman, EPA 
APPENDIX D

CONCEPTUAL MODEL DATA SUMMARIES 


\section{LIST OF ACRONYMS}

Acronym

BLRA

MAP

PEIS

RAP

SOWP

UMTRA

\section{Definition}

baseline risk assessment

management action process

programmatic environmental impact statement

remedial action plan

site observational work plan

Uranium Mill Tailings Remedial Action 
This appendix contains a short description of the conceptual models for the Monument Valley, Tuba City, Rifle, and Riverton sites. The information is drawn from the programmatic environmental impact statement (PEIS). Site-specific documents such as the surface remedial action plan (RAP), the site observational work plan (SOWP), the baseline risk assessment (BLRA), and the water sampling analysis plans contain detailed site information.

The conceptual models are only included for the sites that are prioritized as Category I in the 1991 Uranium Mill Tailings Remedial Action (UMTRA) Project ranking discussed in Section 4.0 of the Ground Water Project management action process (MAP) document. Because the Gunnison prioritization did not take into account the installation of an alternative water supply, it subsequently was downgraded. Monument Valley is included here because it has been moved in Category I to replace Gunnison.

\section{Monument Yalley Arizona}

The Monument Valley UMTRA Project site is in Apache County, Arizona, in an isolated setting along Cane Valley Wash on Navajo Nation land. The site is in a sparsely populated area; the nearest town (Halchita) is 17 miles $(\mathrm{mi})(27$ kilometers [ $\mathrm{km}])$ north. Surface remedial action, which involved removing all the residual radioactive material, was completed in May 1994.

Surface water features at the Monument Valley site consist of Cane Valley Wash and several small ephemeral drainages. The surface water body closest to the site is 2000 feet (ft) 1600 meters [m]) to the east; it is not contaminated. Additional surface water bodies and wetlands downstream from the site $(2.2 \mathrm{mi}$ [3.5 km]) have not been affected by siterelated contamination in ground water.

Ground water occurs in the alluvium and dune sand underneath the Monument Valley site and in the underlying bedrock formations. The depth to ground water in the alluvium is from a few feet in Cane Valley Wash to slightly more than $10 \mathrm{ft}(3 \mathrm{~m})$ under the site. This ground water is recharged by occasional infiitration from precipitation and upward leakage from the underlying aquifers. The ground water in the alluvium flows north at an estimated velocity range of 90 to $200 \mathrm{ft}(27$ to $61 \mathrm{~m})$ per year. Below the alluvial aquifer, ground water occurs in the Shinarump Conglomerate and the confined De Chelly Sandstone aquifer. Ground water flows north at an estimated rate of 6 to $100 \mathrm{ft}(2$ to $30 \mathrm{~m} /$ per year in the Shinarump Conglomerate and $150 \mathrm{ft}(46 \mathrm{~m})$ per year in the De Chelly Sandstone.

Contamination in the alluvial ground water beneath the site has exceeded the maximum concentration limits for cadmium, chromium, molybdenum, net gross alpha, nitrate, radium226 and -228 , and selenium at least once during the years of sampling. A nitrate plume extends approximately $3000 \mathrm{ft}(900 \mathrm{~m})$ north of the site. The estimated amount of contaminated ground water at the Monument Valley site is 1.2 billion gallons (gal) (4.5 million cubic meters $\left[\mathrm{m}^{3} \mathrm{]}\right.$ ). Concentrations of molybdenum, selenium, nitrate, net gross alpha, and radium-226 and -228 have exceeded the maximum concentration limits in the Shinarump Conglomerate. The maximum concentration limits for chromium and uranium have been exceeded in the De Chelly Sandstone. 
Two domestic wells are completed in the alluvial aquifer just south and upgradient of the site. Other residences near the site use artesian ground water from the De Chelly Sandstone that flows from monitor wells or former production wells. Ground water analyses from all these sources show no sign of contamination.

Iuba City Arizona

The Tuba City UMTRA Project site is in Coconino County, Arizona, 6 air mi $(10 \mathrm{~km})$ east of Tuba City on Navajo Nation land. The residual radioactive materials were stabilized on the site in 50 -acre (ac) (20-hectare [ha]) disposal cell. Surface remediation was completed in May 1990.

The site is approximately $7000 \mathrm{ft}(2100 \mathrm{~m})$ northwest of Moenkopi Wash, an intermittent stream that joins the Little Colorado River to the southeast. No other watercourses exist in the vicinity of the site. A natural spring and seeps appear along the base of an escarpment, approximately $6000 \mathrm{ft}(1800 \mathrm{~m})$ east-southeast of the site. The largest of these is used to water livestock. Surface water and sediment sample analysis from Moenkopi Wash and the seeps indicates these areas are not affected by contaminants from the Tuba City site.

The uppermost aquifer at the Tuba City site is in the Navajo Sandstone. The water table ranges from 20 to $150 \mathrm{ft}(6$ to $50 \mathrm{~m})$ deep. Ground water in this aquifer flows southeast toward Moenkopi Wash at an estimated average velocity of 2 to $100 \mathrm{ft}(0.6$ to $30 \mathrm{~m})$ per year. Ground water beneath the site is contaminated, and levels of molybdenum, nitrate, selenium, uranium, and net gross alpha activity have exceeded the maximum concentration limits. The plume of contamination extends approximately $1500 \mathrm{ft}(460 \mathrm{~m})$ downgradient from the site. The estimated amount of contaminated ground water at the Tuba City site is 780 million gal $\left(3\right.$ million $\mathrm{m}^{3}$ ). Ground water is not withdrawn from the plume area. Water is taken from springs near Moenkopi Wash and from the wash itself, downgradient of the site. These use areas are all greater than $1 \mathrm{mi}(1.6 \mathrm{~km})$ from the Tuba City site.

\section{Bifle. Colorado (two sites)}

The Old and New Rifle UMTRA Project sites are near the city of Rifle, Colorado, in Garfield County. The Old Rifle site is $0.3 \mathrm{mi}(0.5 \mathrm{~km})$ southeast of the center of Rifle. The New Rifle site is $2 \mathrm{mi}(3 \mathrm{~km})$ southwest of the center of Rifle. Both Rifle sites are in the floodplain of the Colorado River. Surface remedial action, which involves removing all the residual radioactive materials, is scheduled for completion in July 1996.

Both Rifle sites are underlain by Colorado River alluvium. Beneath the alluvium, semiconfined ground water occurs in the Wasatch Formation. Ground water in the alluvium and in the Wasatch Formation flows southwest. Seasonal water level fluctuations in the river influence flow in the aquifers. During periods of high flow, the river recharges the alluvium. During periods of low river flow, the alluvial aquifer tends to discharge into the river. At the Old Rifle site, the depth to water in the alluvial aquifer ranges from 2 to $12 \mathrm{ft}(1$ to $4 \mathrm{~m})$. At the New Rifle site, depth to water ranges from 5 to $10 \mathrm{ft}(2$ to $3 \mathrm{~m})$. The average linear ground water velocity in the alluvial aquifer is $800 \mathrm{ft}(250 \mathrm{~m})$ per year at the Old Rifle site and $300 \mathrm{ft}(90 \mathrm{~m})$ per year at the New Rifle site. The average linear 
ground water velocity in the Wasatch Formation is $0.3 \mathrm{ft}(0.09 \mathrm{~m})$ per year at the Old Rifle site and $3.0 \mathrm{ft}(0.9 \mathrm{~m})$ per year at the New Rifle site.

The alluvial and Wasatch aquifers are contaminated at both sites. Contaminants introduced into the alluvial ground water from the tailings at the Old Rifle site that exceed the maximum concentration limits are molybdenum, selenium, and uranium, and activities of net gross alpha and radium-226 and -228. In addition, levels of fluoride, vanadium, and zinc are elevated above background levels. In the Wasatch Formation below the Old Rifle site, arsenic, barium, cadmium, chromium, lead, molybdenum, selenium, and uranium concentrations and activities of net gross alpha and radium-226 and -228 are above the maximum concentration limits. Antimony, strontium, vanadium, and zinc are above background levels. The estimated amount of contaminated ground water at the Old Rifle site is 70 million gal $\left(0.25\right.$ million $\left.\mathrm{m}^{3}\right)$. Most of the contaminated ground water at the Old Rifle site discharges into the Colorado River, several hundred feet downriver from the tailings pile.

At the New Rifle site, ground water contamination in the alluvial aquifer extends at least $5000 \mathrm{ft}(1500 \mathrm{~m})$ downgradient from the site. Downgradient contaminant concentrations in the alluvium generally are higher at the New Rifle site than the Old Rifle site.

Concentrations of arsenic, cadmium, chromium, molybdenum, nitrate, selenium, and uranium and net gross alpha activity exceed the maximum concentration limits. In addition, levels of antimony, fluoride, strontium, vanadium, and zinc exceed background levels in the alluvial aquifer. The contamination in the Wasatch Formation at New Rifle extends $3500 \mathrm{ft}$ $(1100 \mathrm{~m} /$ downgradient from the site. The estimated amount of contaminated ground water at the New Rifle site is 600 million gal $\left(2.3\right.$ million $\left.\mathrm{m}^{3}\right)$. Concentrations of arsenic, barium, lead, molybdenum, selenium, uranium, and activities of net gross alphe and radium-226 and -228 exceed the maximum concentration limits, while levels of antimony, fluoride, strontium, sulfide, vanadium, and zinc are elevated above background levels in the Wasatch Formation.

The Colorado River is the primary source of municipal water in the Rifle area. The Colorado River intake is approximately $0.5 \mathrm{mi}(0.8 \mathrm{~km})$ upriver from the Old Rifle site.

\section{Riverton. Wyoming}

The Riverton site is in a rural setting $2 \mathrm{mi}(3 \mathrm{~km})$ southwest of the city of Riverton in Fremont County, Wyoming. The site is on private land within the boundary of the Wind River Indian Reservation. Surface remedial action at the Riverton site, which involved removal of all the residual radioactive materials, was completed in November 1989.

The Riverton site is on alluvial deposits between the Wind River, $1 \mathrm{mi}(1.6 \mathrm{~km})$ to the north, and the Little Wind River, $0.5 \mathrm{mi}(0.8 \mathrm{~km})$ southeast of the site. The confluence of these two rivers is $2.5 \mathrm{mi}(4.0 \mathrm{~km})$ east of the site. The site is bordered by drainage ditches and irrigation canals on the north, east, and southwest sides. Surface water and sediment samples from the drainage ditches and wetlands indicate the site-related contaminated ground water has not adversely affected these bodies of water. The predominant land use in the site vicinity is agricultural; the primary crop is hay grown on irrigated fields. A sulfuric acid plant used during the former uranium milling is still in 
operation near the site boundary. Residences exist along the north, south, southeast, and east boundaries of the site.

Two ground water systems occur in the vicinity of the Riverton processing site. The uppermost aquifer consists of unconfined ground water in the shallow alluvial deposits and the hydrologically connected semiconfined sandstone unit of the Wind River Formation. The second system contains confined ground water in the deeper sandstone layers of the Wind River Formation. Depth to water in the uppermost aquifer is approximately $6 \mathrm{ft}(2 \mathrm{~m})$ below the site; the aquifer has an average saturated thickness of $50 \mathrm{ft}(15 \mathrm{~m})$. Ground water flow in the uppermost aquifer is predominantly to the south-southeast toward the Little Wind River. Water from this aquifer discharges into this river approximately $2800 \mathrm{ft}$ $(850 \mathrm{~m})$ downgradient of the site and probably to the wetlands east and southwest of the site. The estimated ground water velocity is $160 \mathrm{ft}(50 \mathrm{~m})$ per year. Recharge to the uppermost aquifer is from precipitation, snowmelt, and ephemeral and perennial creeks.

Molybdenum, net gross alpha, selenium, radium-226 and -228 , and uranium have exceeded the maximum concentration limits at various times in on-site and downgradient monitor wells in the uppermost aquifer. Currently, only molybdenum and uranium exceed maximum concentration limits in on-site and downgradient ground water. Plume movement is in the direction of ground water flow, which is to the south-southeast. The estimated amount of contaminated ground water at the Riverton site is 500 million gal $\left(1.9\right.$ million $\left.\mathrm{m}^{3}\right)$.

The uppermost aquifer is of low quality. Only two wells in the area of the processing site are known to be completed in this unit. One is about $200 \mathrm{ft}(60 \mathrm{~m})$ upgradient of the site and the other is $2000 \mathrm{ft}(600 \mathrm{~m})$ downgradient along the boundary of the contaminant plume. Both wells are used for livestock watering. There are no known domestic water supply wells in this aquifer system in the site area. The confined aquifer is of good quality and is used for domestic water supplies in the area. 
APPENDIX E

PROJECT CONTROLS

(Rust-Geotech to provide information to the Grand Junction Projects Office for this section on 27 March 1996.) 
This section will summarize of the Project controls system. The summary will be taken from the existing description document, the draft programmatic environmental impact statement (DOE, 1995).

\section{REFERENCE}

DOE (U.S. Department of Energy), 1995. Draft Programmatic Environmental Impact Statement for the Uranium Mill Tailings Remedial Action Ground Woter Project, April 1995, DOE/EIS-0198, Rev. 5, prepared for the U.S. Department of Energy, UMTRA Project Office, Albuquerque Operations Office, Albuquerque, New Mexico. 
